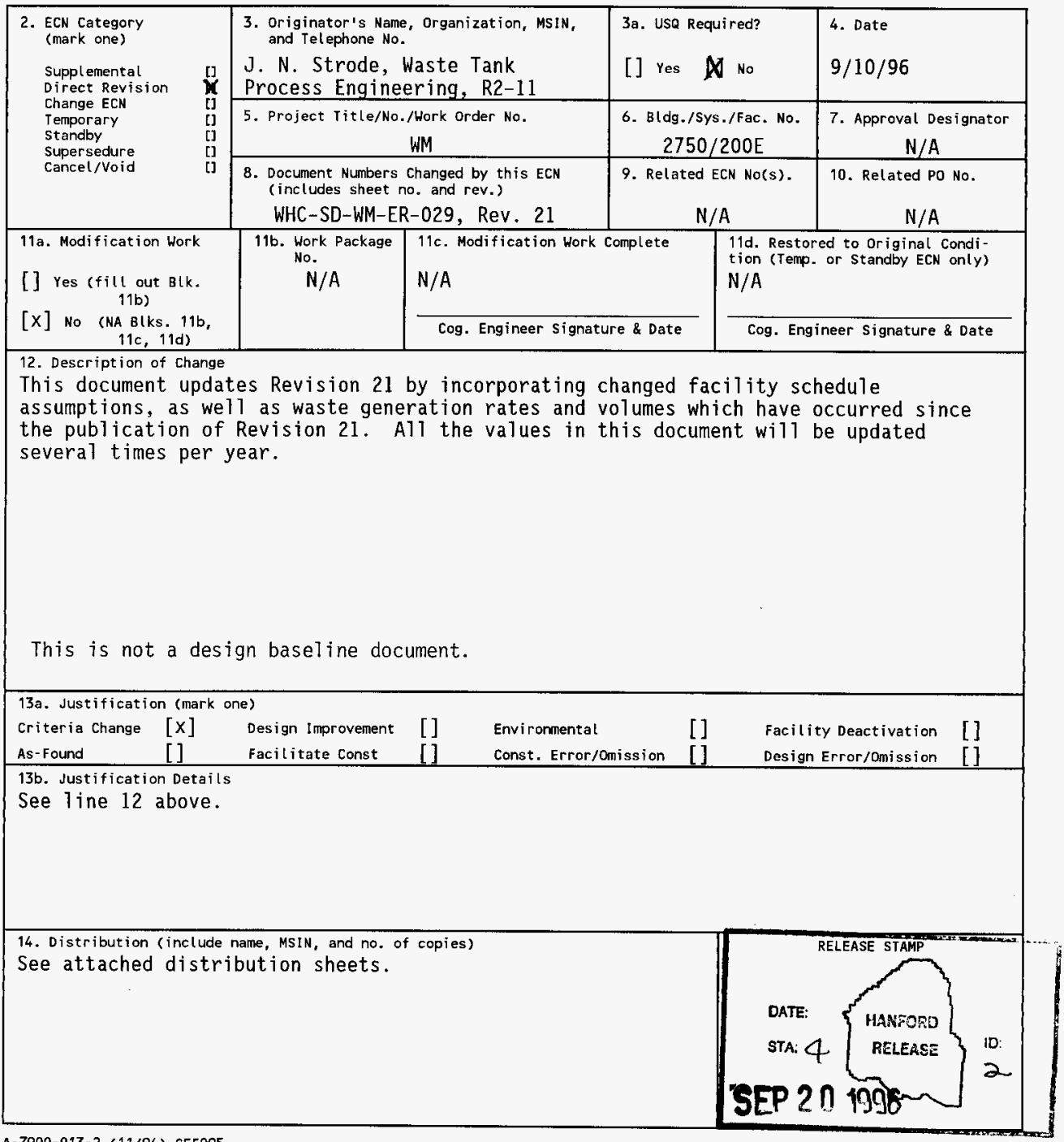




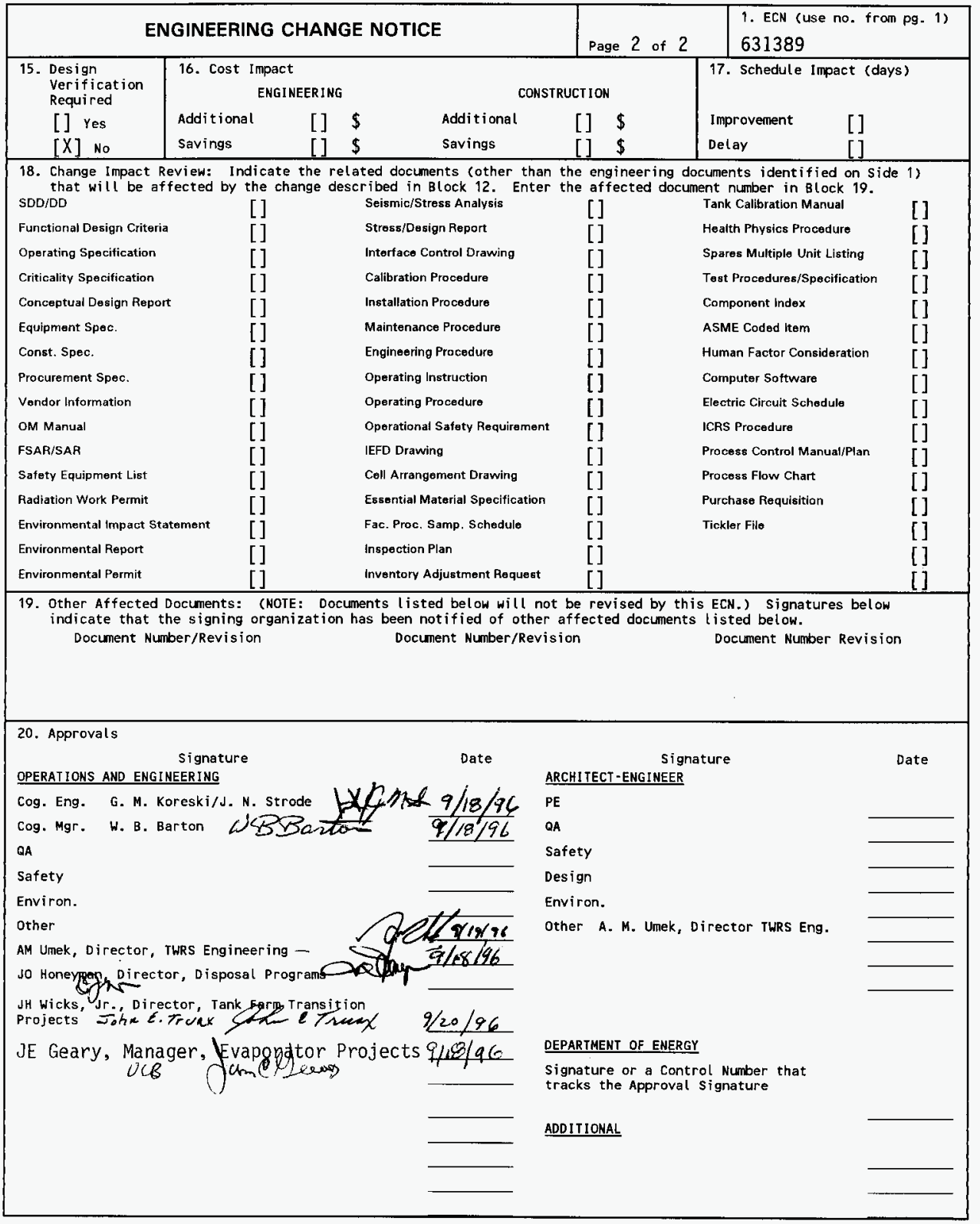


WHC-SD-WM-ER-029, Rev. 22

\section{Operational Waste Volume Projection}

JN Strode/GM Koreski

WHC, Richland, WA 99352

U.S. Department of Energy Contract DE-AC06-87RL10930

EDT/ECN: 631389

UC: 2030

Org Code: 74A10

Charge Code: N1820

B\&R Code: $2 W 3 / 2007 /$

Total Pages: $\theta^{\prime}$

Key Words: Waste Volume Projection, Tank Space Management Board, Waste Volume Reduction, Double-She11 Tank, Evaporator, LERF

Abstract: Waste receipts to the double-shell tank system are analyzed and wastes through the year 2015 are projected based on generation trends of the past 12 months. A computer simulation of site operations is performed, which results in projections of tank fill schedules, tank transfers, evaporator operations, tank retrieval, and aging waste tank usage.

This projection incorporates current budget planning and the clean-up schedule of the Tri-Party Agreement. Assumptions were current as of June 1996.

IRADEMARK DISCLAIMER. Reference herein to any specific comercial product, process, or service by trade name, trademark, manufacturer, or otherwise, does not necessarily consti tute or imply its endorsement, recommendation, or favoring by the United States Government or any agency thereof or its contractors or subcontractors.

Printed in the United States of America. To obtain copies of this document, contact: WHC/BCS

Document Control Services, P.0. Box 1970, Mailstop H6-08, Richland WA 99352, Phone (509) 372-2420; Fax (509) 376-4989.
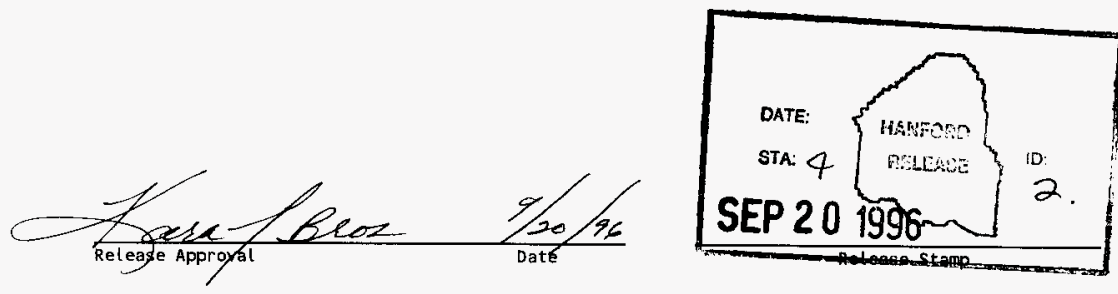


\section{RECORD OF REVISION}

(2) Fitle

Operational Waste Volume Projection
(1) Document Number

SD-WM-ER-029
(3) Revision

(4) Description of Change - Replace, Add, and Delete Pages

(7) Previous revisions have been done on the now obsolete IRACCR and Record of Revision forms.

21 RS Incorporated per ECN 606102

22 Ros Incorporated per ECN 631389
Authorized for Release

(5) Cog. Engr. (6) Cog. Mgr. Date

Miroi.

GM Koreski WB Barton

JN Strode

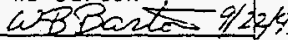

\section{Q.n. Ethate}

onofturt

ontrode

GM Koreski

\begin{tabular}{|l|l|}
\hline & \\
\hline & \\
\hline
\end{tabular}

Covers 


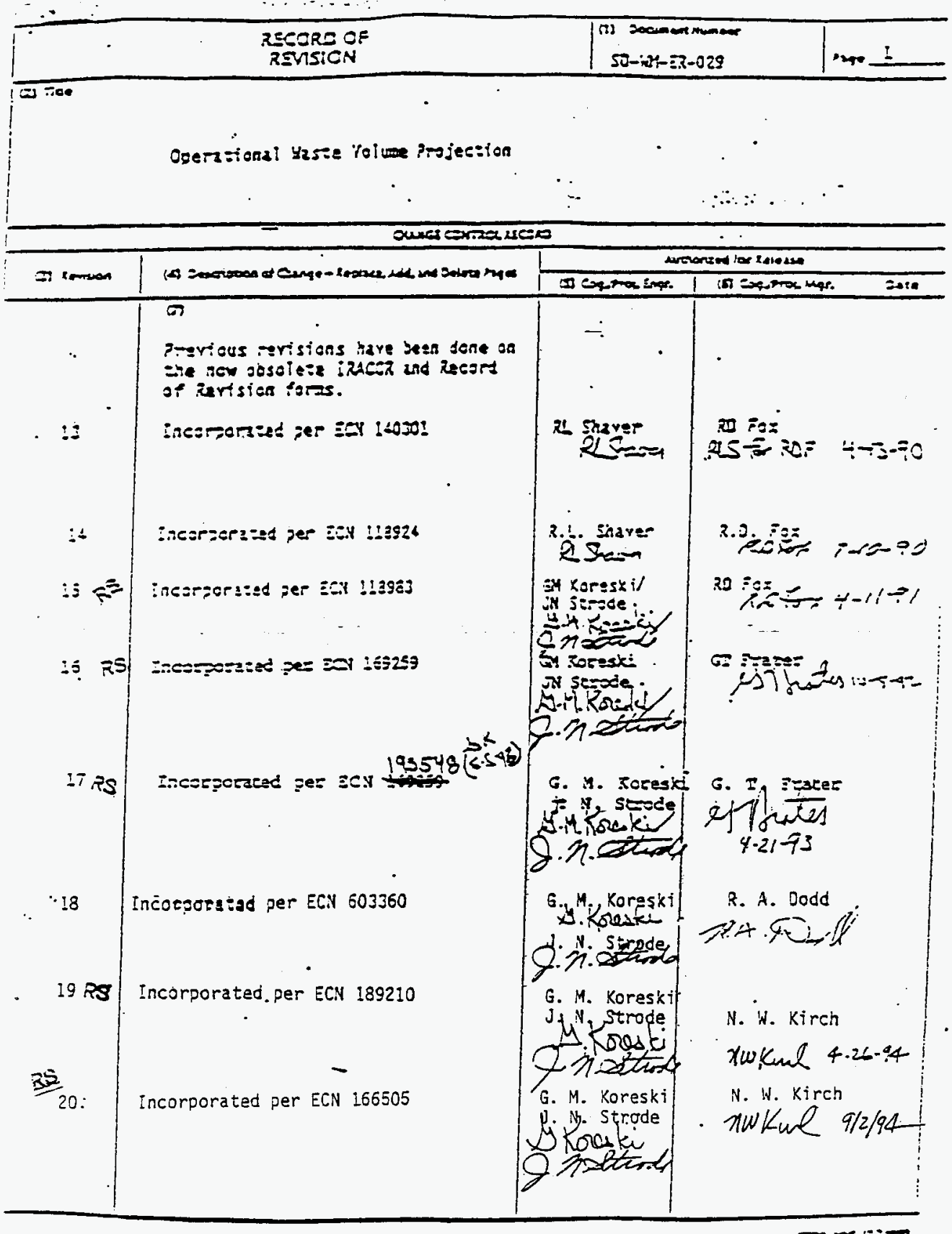


WHC-SD-WM-ER-029 Rev. 22

\section{OPERATIONAL WASTE VOLUME PROJECTION}

\section{JUNE 1996}

Prepared by

JN Strode

GM Koreski 
WHC-SD-WM-ER-029 Rev. 22

This Page Intentionally Left Blank 


\section{TABLE OF CONTENTS}

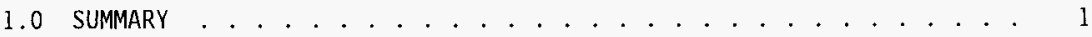

2.0 INTRODUCTION . . . . . . . . . . . . . . . . . . . . . . . 5

2.1 Purpose . . . . . . . . . . . . . . . . . . . . . . . . . . 5

2.2 Methodology . . . . . . . . . . . . . . . . . . . 5

3.0 GENERAL FACILITY DESCRIPTIONS AND ASSUMPTIONS . . . . . . . . . . . 7

3.1 B Plant/WESF . . . . . . . . . . . . . . . . . . . . . 7

3.2 242-A Evaporator and LERF . . . . . . . . . . . . . . . 7

3.3 Grout . . . . . . . . . . . . . . . . 10

3.4 Effluent Treatment Facility ................ 10

3.5 PFP . . . . . . . . . . . . . . . . . . . . 11

3.6 PUREX . . . . . . . . . . . . . . . . . . . . . . . . 11

3.7 S Plant . . . . . . . . . . . . . . . . . . 12

3.8 Salt Well Liquid Pumping . . . . . . . . . . . . . . . . 12

3.9 Single-Shel1 Tank Solids Retrieval . . . . . . . . . . . . . . 14

3.10 Solid Waste Trench 31 Leachate . . . . . . . . . . . . . . . . 15

3.11 T Plant . . . . . . . . . . . . . . . . 15

3.12 Tank Farms... . . . . . . . . . . . . . . . . . 16

$3.13 \mathrm{UO}_{3} \mathrm{Facility}$. . . . . . . . . . . . . . . . . . . . . . . 19

3.14 Waste Sampling and Characterization Facility (WSCF) . . . . . 19

3.15100 Area . . . . . . . . . . . . . . . . . 19

3.16300 Area ..................... . . . 20

3.17400 Area... . . . . . . . . . . . . . . . . 20

3.18 Phase I Privatization Processing . . . . . . . . . . . . . . 20

3.19 Phase II Privatization Processing . . . . . . . . . . . . . . 25

3.20 Watch List/Safety . . . . . . . . . . . . . . . . . 25

3.21 Spare/Contingency Space ................. . . . 25

3.22 Waste Segregation .. . . . . . . . . . . . . . 25

3.23 LosS of DST Space . . . . . . . . . . . . . . . . . 27

3.24 New DST Construction . . . . . . . . . . . . . . . . . 27

3.25 DST Tank Solids Levels . . . . . . . . . . . . . . . 27

3.27 IMUST Wastes . . . . . . . . . . . . . . . . . . . . . . . . . 27

3.28 As sumption Summary . . . . . . . . . . . . . . . . . 27

4.0 LOWER AND UPPER PLANNING CASE ASSUMPTIONS . . . . . . . . . . . . . 32

4.1 Lower Planning Case Assumptions . . . . . . . . . . . . . . . . 32

4.2 Upper Planning Case Assumptions . . . . . . . . . . . . . . . . 33

5.0 RESULTS AND CONCLUSIONS . . . . . . . . . . . . . . . . . . . . . . 34

5.1 Baseline Case Results and Conclusions . . . . . . . . . . . . . 34

5.2 Lower Planning Case Results and Conclusions . . . . . . . . . . 59

5.3 Upper Planning Case Results and Conclusions . . . . . . . . . . 61

5.4 Actual Waste Generation Compared to Management Limits . . . . . 63

6.0 SPACE SAVING ALTERNATIVES . . . . . . . . . . . . . . . . . . . 69

7.0 BIBLIOGRAPHY . . . . . . . . . . . . . . . . . . . 71

\section{APPENDICES}

Acronyms 


\section{TABLE OF CONTENTS (CONTINUED)}

\section{FIGURES}

1. Comparison of the Tank Requirements for the $6 / 96$ Projection Cases . 2

2. Methodology of the OWVP ............... 5

3. Double-Shell Tank Requirements for the Baseline Case . . . . . . . . 38

4. Double-Shell Tank Inventory and Space for the Baseline Case . . . . 40

5. Facility Waste Generation Graphic . . . . . . . . . . . . . . . 43

6. Tank Fill Graphic . . . . . . . . . . . . . . . . . . . . . . . . . 43

7. Tank Levels During Four-Year Projection . . . . . . . . . . . . . 45

8. Simplified Schematic of Current and Planned Routings . . . . . . . . 46

9. Dilute Receiver Tanks and 242-A Evaporator Operations . . . . . . . 50

10. PUREX Facility Waste Generation and Tank Levels . . . . . . . . . . 52

11. West Area Waste Generation and SY Tank Levels . . . . . . . . . . . 53

12. B Plant and Hanford Facility Waste . . . . . . . . . . . . . . . 54

13. AP Farm Tank Levels . . . . . . . . . . . . . . . . . . . . 55

14. AN Farm Tank Levels . . . . . . . . . . . . . . . . . . . . . 56

15. Aging Tank Requirements . . . . . . . . . . . . . . . . 57

16. Aging Waste Tank Usage . . . . . . . . . . . . . . . . . . . 58

17. Doub1e-She11 Tank Requirements for the Lower Planning Case . . . . . 60

18. Double-Shell Tank Requirements for the Upper Planning Case . . . . . 62

19. Monthly Facility Generations . . . . . . . . . . . . . . . . . . . 64

20. Comparison of Monthly Average Waste Generation to Target Rate . . . 65

21. Monthly Contributions from SWL Pumping . . . . . . . . . . . . 66

22. Contributions from Facility TCO . . . . . . . . . . . . . . 67

\section{TABLES}

1. Summary of Assumptions For the June 1996 Projection Cases . . . . . 3

2. Risk Assessment Summary for Waste Volume Projections . . . . . . . . 4

3. Salt Well Pumping Schedule for the Baseline Case . . . . . . . . . . 13

4. Operational Tanks and Usage . . . . . . . . . . . . . . . . 17

5. Summary of In-Tank Washing Activities . . . . . . . . . . . . . . 23

6. Projected Pretreatment Schedule for Phase I . . . . . . . . . . . . 24

7. Waste Compatibility Matrix . . . . . . . . . . . . . . . . . . 26

8. DST Solids Levels (Kgal) . . . . . . . . . . . . . . . . . 27

9. Assumption Matrix .. . . . . . . . . . . . . . . . . . . 28

10. Spreadsheet of Waste Additions and Reductions for Baseline Case . . 39

11. Evaporator WVR and LERF Additions for the Baseline Case . . . . . . 47

12. Evaporator Campaign Schedule for the Baseline Case . . . . . . . . . 48

13. Comparison of Average Monthly Waste Generation Rates . . . . . . . . 63

14. Facility Waste Storage and Capacity . . . . . . . . . . . . 68 


\subsection{SUMMARY}

The 0perational Waste Volume Projection (OWVP) presents a basis for evaluating future Double-Shel1 Tank (DST) space through FY 2015. This report presents a projected range of tank needs which is used to generate recommendations regarding site activities, waste management activities, facility requirements, and the need to build additional double-shell tanks. This document presents the results of three distinct projections cases (Baseline, Lower Planning, and Upper Planning Cases). Operating assumptions for the three cases were established prior to June 1996:

- The Baseline Case presents projected DST needs based on TPA milestones, TWRS program planning, and the current operational assumptions. The Baseline Case does not require construction of additional DSTs through FY 2015.

- The Lower Planning Case predicts the impacts of a delay in SWL pumping and SST solids retrieval. This projection does not exceed available space through FY 2015.

- The Upper Planning Case presents the impacts of a one tank loss in FY 1998, an evaporator outage in 2003, and an evaporator shutdown from Fy 2011 on. This projection, as expected, exceeds available space. The excess tank space requirements from 2013 on confirm the need to maintain evaporation capacity to avoid the need for building new tanks or delaying TPA milestones.

A comparison of the projected tank space needs required for the three projection cases is depicted in Figure 1. Key assumptions for the three projection cases are summarized in Table 1. Differences in assumptions have been highlighted. Detailed assumptions and space saving alternatives are presented later in this document. A brief summary of the risks associate with these projections is provided in Table 2. At a minimum, this DST space forecast will be updated annually with the latest information available regarding the estimated volume of waste requiring storage in the DSTs.

\section{Areas Requiring Management Consideration}

Facility waste minimization requirements initiated by the Tank Space Management Board (TSMB) helped to guarantee tank space availability prior to the 242-A Evaporator restart. However, considering the possibility of future tank space shortages, the Terminal Clean-out (TCO) and monthly waste generations will continually need to be minimized.

Should a tank space shortage occur during the projection period (Figure 1), the shortage could be solved using a combination of the following actions (see Section 6.0 for a more complete 1 isting):

0 delay the Single-Shell Tank (SST) stabilization

0 delay the SST solids retrieval

0 accelerate pretreatment and vitrification of waste

0 construct new double-shell tanks

0 establish Phase II contract terms for privatization to require rates of retrieval and processing equivalent to TPA rates 


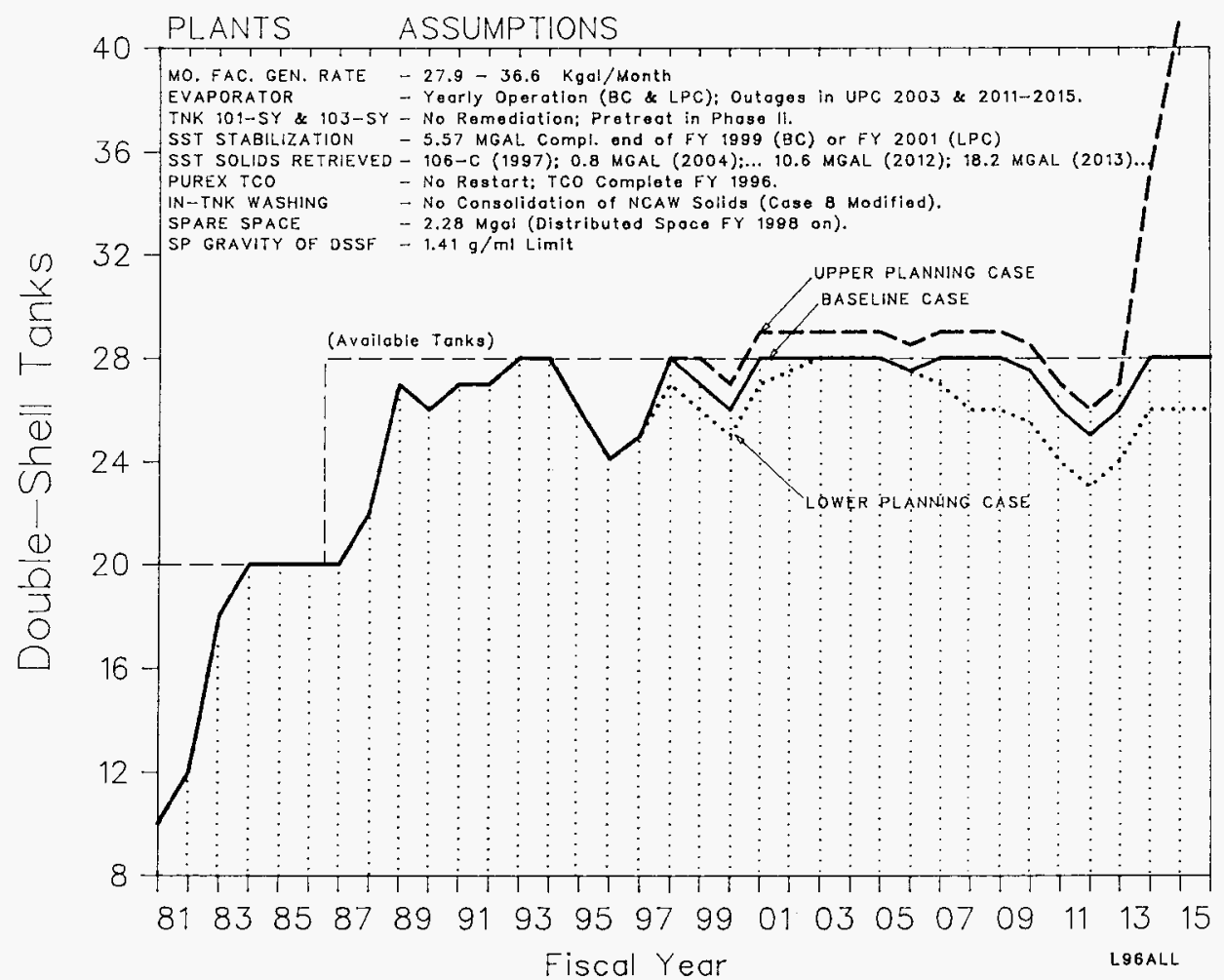

Figure 1. Comparison of Tank Requirements For The 6/96 Projection Cases 
Table 1. Summary of Assumptions For the June 1996 Projection Cases (references in Sect. 3)

\begin{tabular}{|c|c|c|c|}
\hline Facility or Project & $\begin{array}{c}\text { Basel ine Case (L96BC) } \\
\text { Assumptions }\end{array}$ & $\begin{array}{l}\text { Lower Planning Case (L96LC) } \\
\text { Assumptions }\end{array}$ & $\begin{array}{l}\text { Upper Planning Case (L96UC) } \\
\text { Assumptions }\end{array}$ \\
\hline Total Monthly Facility Generations & 27.9-36.6 Kgal/month & $27.9-36.6 \mathrm{Kgal} /$ month & $27.9-36.6 \mathrm{kgal} /$ month \\
\hline PUREX TCO & TCO FY96 (0.045 Mgal DN $)$ & TCO FY96 (0.045 Mgal DN) & TCO FY96 (0.045 Mgal DN) \\
\hline B Plant TCO & ICO FY96-98(0.125 Mgal DN) & TCO FY96-98 (0.125 Mgat DN) & ICO FY96-98 (0.125 Mgal DN) \\
\hline $100 \mathrm{~N}$ Area TCO & TCO FY97 (0.014 Mgal DN \& solids? & TCO FY97 (0.014 Mgal DN \& solids) & TCO FY97 (0.014 Mgal DN \& solids) \\
\hline 100K Area $\mathrm{TCO}$ & TCO FY97-00 (0.35 Mgal DN) & TCO FY97-00 (0.35 Mgal DN) & TCO FY97-00 (0.35 Mgal DN) \\
\hline $105 \mathrm{~F} \& \mathrm{H}$ Basin Cleanout & TCO FYOO-03 (0.24 Mgal DN) & TCO FYOD-03 (0.24 Mgal DN) & ICO FYOO-03 (0.24 Mgal DN) \\
\hline $\begin{array}{l}\text { Evaporator Operation } \\
\text { Outage }\end{array}$ & $\begin{array}{l}\text { Yearly beyond } 2015 \\
\text { None }\end{array}$ & $\begin{array}{l}\text { Yearly beyond } 2015 \\
\text { None }\end{array}$ & 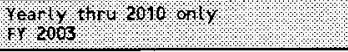 \\
\hline $\begin{array}{l}\text { Liquid Effluent Treatment Facility } \\
\text { Startup } \\
\text { Rate (Mgal/Year) }\end{array}$ & $\begin{array}{l}11 / 1995 \\
50\end{array}$ & $\begin{array}{l}11 / 1995 \\
50\end{array}$ & $\begin{array}{l}11 / 1995 \\
50\end{array}$ \\
\hline $\begin{array}{l}\text { SST Stabilization } \\
\text { Porosity Sal tcake/Sludge } \\
\text { Complexed SWL } \\
\text { Volume Pumped } \\
\text { Volume Pumped } 1997-98\end{array}$ & $\begin{array}{l}50 \% / 21 \% \\
1.75 \mathrm{Mgal} \\
-5.57 \mathrm{Mgal}(1996-99) \\
4.47 \mathrm{Mgal}(1997-98)\end{array}$ & 507/ 2. & $\begin{array}{l}50 \% / 21 \% \\
1.75 \mathrm{Mgat} \\
-5.57 \mathrm{Mgal}(1996-99) \\
4.47 \mathrm{Mgal}(1997-98)\end{array}$ \\
\hline PFP Stabilization & $30 \mathrm{Kgal}$ (FY 1996-2006) & $30 \mathrm{Kgal} \mathrm{(FY} \mathrm{1996-2006)}$ & $30 \mathrm{Kgal} \mathrm{(FY} \mathrm{1996-2006)}$ \\
\hline Tank 101-SY Dilution (Date) & No Dilution until treatment (2011) & No Dilution until treatment (2011) & No Dilution until treatment (2011) \\
\hline Tank 103-SY Dilution (Date) & No Dilution until treatment (2011) & No Dilution unt il treatment (2011) & No Dilution until treatment (2011) \\
\hline $\begin{array}{l}\text { SST Solids Retrieval } \\
106-C \text { solids (start; receiver tank) } \\
\text { SST Solids Retrieval Start } \\
\text { Rate } \\
\text { SST Waste Retrieval Complete } \\
\text { SST Site Closure Complete }\end{array}$ & $\begin{array}{l}\text { FY 1997; Tank 102-AY } \\
12 / 2003 \\
2.8 \mathrm{Mgal} \text { in FY 2004-2005; } \\
4.1 \mathrm{Mgal} \text { in FY 2006-2007; } \\
\text { FY } 2018 \\
\text { FY } 2024\end{array}$ & 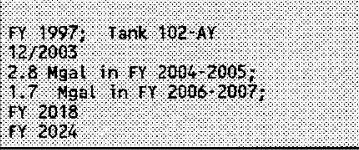 & $\begin{array}{l}\text { FY 1997; Tank 102-AY } \\
12 / 2003 \text {; } \\
2.8 \mathrm{Mgal} \text { in } \mathrm{FY} 2004-2005 ; \\
4.1 \mathrm{Mgal} \text { in } \mathrm{FY} 2006-2007 ; \\
\text { FY } 2018 \\
\text { FY } 2024\end{array}$ \\
\hline Phase I Privatization Processing startup & $06 / 2002$ & $06 / 2002$ & $06 / 2002$ \\
\hline LAW Pretreatment Rate (Mgal/Yr) & $\begin{array}{l}2.03 \text { in } 1 \text { st Year }(6 / 2002-5 / 2003) \\
2.22 \text { in 2nd Year }\end{array}$ & $\begin{array}{l}2.03 \text { in 1st Year }(6 / 2002-5 / 2003) \\
2.22 \text { in 2nd Year }\end{array}$ & $\begin{array}{l}2.03 \text { in 1st Year }(6 / 2002-5 / 2003) \\
2.22 \text { in 2nd Year }\end{array}$ \\
\hline $\begin{array}{l}\text { LAW Vendor Tanks } \\
\text { LAW Intermediate Staging Tanks } \\
\text { Entrained Solids Receipt Tank }\end{array}$ & $\begin{array}{l}2(f u l l) \\
2 \\
1\end{array}$ & \begin{tabular}{|l}
$2($ full $)$ \\
2 \\
1 \\
\end{tabular} & $\begin{array}{l}2(f u l l) \\
2 \\
1\end{array}$ \\
\hline $\begin{array}{l}\text { Phase II Privatization } \\
\text { Maximum Processing Rate, Mgal/Yr a } 7 \mathrm{M} \mathrm{Na} \\
\text { HLW Vitrification startup }\end{array}$ & $\begin{array}{l}2011 \\
22.1 \\
2013 \\
\end{array}$ & $\begin{array}{l}2011 \\
22.1 \\
2013 \\
\end{array}$ & $\begin{array}{l}2011 \\
22.1 \\
2013 \\
\end{array}$ \\
\hline $\begin{array}{l}\text { In-Tank Washing (FY 1998-2004) } \\
\text { Consol idate NCAW solids } \\
\text { Consol idate NCAW supernates to }\end{array}$ & $\begin{array}{l}\text { Case } 8 \text { Modified } \\
\text { No } \\
101 \text {-AY + } 1 \text { DST }\end{array}$ & $\begin{array}{l}\text { Case } 8 \text { Modified } \\
\text { No } \\
101-\text { AY }+1 \text { DST }\end{array}$ & $\begin{array}{l}\text { Case } 8 \text { Modified } \\
\text { No } \\
101-\text { AY }+1 \text { DST }\end{array}$ \\
\hline Evaporation Limit for Wastes--SpG & 1.41 & 1.41 & 1.41 \\
\hline Spare Space & 2.28 & 2.28 & 2.28 \\
\hline Contingency Tank. & None & None & None \\
\hline Loss of DST Space & None & None & $(1$ rant $(1088)$ \\
\hline
\end{tabular}


Table 2. Risk Assessment Summary for Waste Volume Projections

\begin{tabular}{|c|c|c|c|c|c|c|c|c|c|}
\hline \multicolumn{10}{|c|}{ RISK ASSESSMENT SUMMARY FOR WASTE VOLUME PROJECTIONS } \\
\hline \multirow[t]{2}{*}{$\begin{array}{l}\text { Technical/Program Basis } \\
\text { for Waste Volume } \\
\text { Projections }\end{array}$} & \multicolumn{3}{|c|}{$\begin{array}{l}\text { Confidence } \\
\text { of Basis } \\
\text { Being } \\
\text { Accurate } \\
\end{array}$} & \multicolumn{3}{|c|}{ Waste Volume Impact if Wrong } & \multicolumn{2}{|c|}{$\begin{array}{l}\text { Consequence } \\
\text { if } \\
\text { Assumption } \\
\text { Wrong }\end{array}$} & \multirow[t]{2}{*}{ COMMENTS } \\
\hline & $\mathrm{HIGH}$ & MED & LO & MAJOR & MINOR & QUANT ITY & MAJOR & MINIMAL & \\
\hline $\begin{array}{l}\text { Remaining SWL pumping } \\
\text { volume is } 5.57 \text { Mgal }\end{array}$ & & $\mathrm{X}$ & & $x$ & & $\begin{array}{l}\text { Dependent on } \\
\text { magnitude of change }\end{array}$ & $x$ & & $\begin{array}{l}\text { Delay TPA milestones; Large } \\
\text { concentrated volume; Section } \\
3.8\end{array}$ \\
\hline $\begin{array}{l}\text { CC waste and TRU sludge } \\
\text { in Tank } 102-S Y \text { are } \\
\text { compatible }\end{array}$ & & & $x$ & $x$ & & $\begin{array}{l}\text { Dependent on } \\
\text { magnitude of change }\end{array}$ & $x$ & & $\begin{array}{l}\text { Could delay SWL pumping TPA } \\
\text { milestones; Sect. } 3.8\end{array}$ \\
\hline $\begin{array}{l}\text { 242-A Evaporator } \\
\text { available without an } \\
\text { outage to } 2015\end{array}$ & & $\mathrm{X}$ & & $x$ & & $\begin{array}{l}\text { Dependent on } \\
\text { magnitude of change }\end{array}$ & $x$ & & $\begin{array}{l}\text { Tank Space Projections based } \\
\text { on concentrated volumes; } \\
\text { Sect. } 3.2\end{array}$ \\
\hline $\begin{array}{l}\text { Evaporation limit for new } \\
\text { DSSF will be SpG of } 1.41\end{array}$ & & $\mathrm{X}$ & & $x$ & & $\begin{array}{c}\text { Dependent on } \\
\text { magnitude of change }\end{array}$ & $x$ & & $\begin{array}{l}\text { Reduction in SpG could be } \\
\text { required by safety; Sect. } 3.2\end{array}$ \\
\hline $\begin{array}{l}\text { Facility generations will } \\
\text { not exceed Base Case } \\
\text { levels }\end{array}$ & & 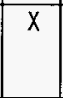 & & & 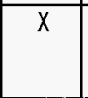 & $\begin{array}{l}\text { Dependent on } \\
\text { magnitude of change }\end{array}$ & & $X$ & $\begin{array}{l}\text { Small concentrated volume; } \\
\text { could delay site cleanup; } \\
\text { Sect. } 3.0\end{array}$ \\
\hline $\begin{array}{l}\text { Facility TCO volumes: } \\
\text { PUREX }<0.045 \mathrm{Mgal} \\
\text { B Plant }<0.125 \mathrm{Mgal} \\
100 \text { Areas }<0.6 \mathrm{Mgal}\end{array}$ & & $x$ & & & $x$ & $\begin{array}{c}\text { Dependent on } \\
\text { magnitude of change }\end{array}$ & & $X$ & $\begin{array}{l}\text { Could delay site cleanup; } \\
\text { Sect. } 3.0\end{array}$ \\
\hline No loss of DST space & & $\bar{x}$ & & $\bar{x}$ & & $1 \mathrm{mgal} / \mathrm{tank}$ & $x$ & & Sect. 3.23 \\
\hline $\begin{array}{l}\text { LAW Phase I treatment } \\
\text { starts FYO2; } 2.2 \mathrm{Mgal} / \mathrm{yr}\end{array}$ & & $\bar{x}$ & & $x$ & & $\begin{array}{c}\text { Dependent on } \\
\text { magnitude of change }\end{array}$ & $x$ & & $\begin{array}{l}\text { Could delay SST solids } \\
\text { retrieval (TPA); Sect. } 3.18\end{array}$ \\
\hline $\begin{array}{l}\text { LAW Phase II treatment } \\
\text { starts FYll; } 22.1 \mathrm{Mgal} / \mathrm{yr}\end{array}$ & & $x$ & & $x$ & & $\begin{array}{l}\text { Dependent on } \\
\text { magnitude of change }\end{array}$ & $x$ & & $\begin{array}{l}\text { Could delay SST solids } \\
\text { retrieval (TPA); Sect. } 3.19\end{array}$ \\
\hline $\begin{array}{l}\text { Crossite transfer lines } \\
\text { are available }\end{array}$ & & $x$ & & $x$ & & $\begin{array}{l}\text { Dependent on } \\
\text { magnitude of change }\end{array}$ & $x$ & & $\begin{array}{l}\text { Could delay SWL pumping TPA } \\
\text { milestones and/or site cleanup } \\
\text { Sect. } 3.12\end{array}$ \\
\hline $\begin{array}{l}\text { Use Grout in emergencies } \\
\text { to free up } 2-3 \mathrm{Mgal} \text { of } \\
\text { space }\end{array}$ & & & $x$ & $x$ & & $\begin{array}{l}\text { Dependent on } \\
\text { magnitude of change }\end{array}$ & $x$ & & $\begin{array}{l}\text { DoE and public acceptance } \\
\text { un } 1 \text { ike } 1 y ; \text { Sects. } 3.3 \& 5.1\end{array}$ \\
\hline $\begin{array}{l}\text { No volume set aside for } \\
\text { upsets or new streams }\end{array}$ & & & $x$ & & $x$ & $\begin{array}{l}\text { Dependent on } \\
\text { magnitude of change }\end{array}$ & $x$ & & $\begin{array}{l}\text { Consequences depend on volume, } \\
\text { composition, and timing } \\
\text { Sect. 3.21 }\end{array}$ \\
\hline
\end{tabular}




\subsection{INTRODUCTION}

\subsection{Purpose}

The purpose of the Operational Waste Volume Projection (OWVP) is to present a basis for evaluating future Double-Shel1 Tank (DST) needs to meet Tri-Party Agreement Milestone (TPA) M-46-00. This report presents a projected range of tank needs which is used to generate recommendations regarding site activities, waste management activities, facility requirements, and the need to build additional DSTs. This document presents the results of three projections cases (Baseline, Lower Planning, and Upper Planning Cases) which represent varying degrees of tank space demands. A11 projection cases incorporate the "privatization" of waste treatment and disposal. The term "privatization" refers to the revised DOE strategy for treatment of Hanford tank wastes which would use private contractors to design, permit, build, operate, and deactivate the facilities for waste treatment and immobilization (DOE, 1995). The Baseline Case is intended to present tank space needs based on TPA milestones, TWRS program planning, and current operational assumptions. The Lower Planning Case was completed using assumptions requested which might lower tank space needs. The Upper Planning Case uses an assumption requested by the Washington Department of Ecology and others which will increase tank space needs. Operating assumptions for the three cases were established prior to June 1996. Need dates for new DST construction, tank retrievals, facility schedules, waste generation reductions, conflicts in meeting TPA milestones (WDOE, 1994; WHC, 1996a; WHC, 1996b), and funding priorities can then be reviewed in relation to tank space availability.

\subsection{Methodology}

The process followed in preparing an OWVP is shown in Figure 2, below.

\section{Methodology of Waste Volume Projection}

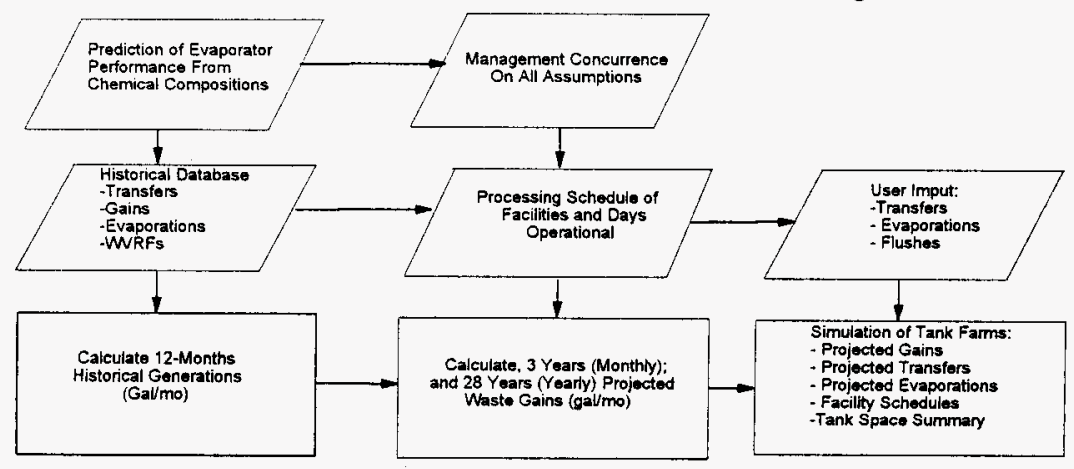

Figure 2. Methodology of the OWVP 
The process of updating the OWVP begins with the request for updated facility or project "assumptions" from each of the operating facilities and projects that will contribute waste to DST inventory. The term "assumption" in this document refers to engineering inputs or bases supplied by the facilities based on their future operational plans (determined by budget, DOE directive, TPA milestones, etc.). Typical assumptions include operating schedules, waste generation rates, stream compositions, modes of operation, etc. The operating facilities and projects provide estimates of volume, composition, and radionuclide content data for each distinct waste stream exiting the facility. In addition to the projected facility waste generation rates, the processing schedules of each of the plants are factored into the projection. For the Plutonium-Uranium Extraction (PUREX) facility, B Plant, and 100 Area

facilities the projected volumes of waste generated from TCO are estimated and entered. For the Plutonium Finishing Plant (PFP), 300 Area, 400 Area, and Tank Farms, monthly waste generations are entered from facility inputs and/or actual observed generation rates. These projected waste generation rates and plant schedules are used to project waste volumes that each plant will be producing per month or year. The composition data is used to calculate Waste Volume Reduction Factors (WVRFs) and to determine waste segregation requirements (due to chemical, radionuclide, or heat content). The WVRF (Riley, 1988) is defined as the percent of water (by volume) that can be removed from a waste stream to achieve a certain interim waste form such as double-shell slurry feed. From the facility assumptions, a matrix of basic assumptions for the three cases to be incorporated into the OWVP projections were prepared and presented to WHC management and program office for approval.

Once the projection cases have been approved, the database of past waste gains, transfers, and evaporations is updated with data from the most recent months of Tank Farm operations. The early years of the projection are simulated in more detail than the later years. In the first period of the projection, monthly waste volumes are predicted. For the last years of the projection, yearly waste volumes are predicted.

The processing sequence in the simulation is designed to model the actual activities in the tank farms. After a dilute receiver tank is filled with waste, the contents are transferred to an available holding tank. The dilute waste must remain in the holding tank for at least four months to allow for sampling and characterization before it can be transferred to the 242-A Evaporator feed tank (Tank 102-AW) for evaporation. After dilute waste is concentrated in the 242-A Evaporator, it is sent to a slurry receiver tank (Tank 106-AW) as Double-Shell Slurry Feed (DSSF) which will eventually be disposed of through the Low-Activity Waste (LAW) pretreatment and vitrification process.

The processing sequence for the Neutralized Current Acid Waste (NCAW) solids is for the solids to be washed in-tank and then immobilized in the High-Level Waste (HLW) vitrification plant. The separated supernates and washes will be pretreated to form high-level and low-activity waste streams. The HLW vitrification facility will incorporate high-level and transuranic (TRU) wastes into a glass matrix for disposal. The low-activity waste stream wi\}l be sent to LAW vitrification for final disposa?. 


\subsection{GENERAL FACILITY DESCRIPTIONS AND ASSUMPTIONS}

A brief description of the facilities and projects pertinent to this projection are listed in the following section. Facility operating dates, waste generation volumes, WVRFs, flushes, and other pertinent assumptions are described. This information has been summarized for each of the three cases in Table 9, which is included at the end of this section. The spreadsheet for the Baseline Case (Section 5.1) lists the waste generations for each year for facilities that presented a range of waste generation rates (e.g., S Plant and T Plant).

\subsection{B Plant/WESF}

B Plant was constructed in 1945 to recover plutonium by the bismuth phosphate process. The facility was refurbished in 1967 to recover cesium and strontium byproducts from the high level waste tanks (Kutsch, 1996a). In 1974, the Waste Encapsulation and Storage Facility (WESF), was constructed on the west end of B Plant to support B Plant's mission. WESF's original mission was to encapsulate, cool, store, and monitor the high heat generating cesium and strontium capsules. The byproduct recovery mission was completed in FY 1984 and B Plant was once considered for waste pretreatment. B Plant is no longer considered a viable option for pretreatment of Hanford tank waste and is presently transitioning to shutdown in FY 1998.

B Plant discharges a low-level miscellaneous waste stream (dilute noncomplexed waste) resulting from cell drainage, vessel clean-out, condensate collection, etc. Future TCO activities will generate wastes that can be separated into three categories (Smith, 1994): 1) aqueous phase waste generated during organic solvent removal (may be complexed waste); 2) dilute non-complexed (DN) waste; and 3) uncharacterized waste resulting from vessel flushing (assumed to be DN waste). Uncharacterized wastes will be characterized when they are produced.

B Plant/WESF projected miscellaneous waste generations for the Baseline Case (Kutsch, 1996b) were $9 \mathrm{Kgal} /$ month during FY 1996 and $5 \mathrm{Kgal} /$ month until plant stabilization has been completed. Cleanout and stabilization of B Plant is estimated to occur from FY 1996-1998 and will generate approximately $125 \mathrm{Kgal}$ of additional uncharacterized (assumed to be dilute non-complexed in this projection) TCO wastes (Kutsch, 1996). When B Plant has completed TCO, WESF will continue to generate approximately $5 \mathrm{Kgal} /$ year of waste from 1999-2028. The WVRF to evaporate either B Plant miscellaneous or TCO waste to DSSF is 99 (Sederburg, 1995). No flushes are anticipated for B Plant miscellaneous or TCO streams based on their dilute nature and lack of solids.

A11 three cases in this document were based on the waste generations described above. The upper waste rate supplied by B Plant engineers (Kutsch, 1996b) would increase the B Plant/WESF monthly waste generation from $5 \mathrm{Kgal} / \mathrm{month}$ to approximately $8 \mathrm{Kgal} /$ month from 1997-1998.

\subsection{2-A Evaporator and LERF}

The 242-A Evaporator was restarted on Apri1 15, 1994. To understand the projection model for the 242-A Evaporator, it is necessary to understand the waste flow during evaporator operation and the simulation model. Waste from 
the dilute holding tanks are transferred into the evaporator feed tank (Tank 102-AW). Waste in the feed tank is then transferred to the 242-A Evaporator for boil-down. In the evaporator operation, four to six months is required for wastes to be sampled and analyzed per Evaporator DQO requirements (Von Bargen, 1995) before they can be evaporated.

- This projection model assumed that the 242-A Evaporator would operate in a "Linked Run" process mode (Guthrie, 1993). A "Linked Run" is a continuous operation of the 242-A Evaporator, made possible by simultaneously transferring from the DST's to the Evaporator feed tank (Tank 102-AW).

- A period of four to six months is required from the time a holding tank is filled with dilute wastes before the waste can be evaporated. This period allows time for sampling and analysis, documentation, and facility preparation (Guthrie, 1993). These projections assumed that a four month period would be required for these purposes.

- In the computer simulation, dilute waste is transferred to the evaporator feed tank (Tank 102-AW) for evaporation. Provided the waste has not reached its concentration limit, the monthly evaporation is continued until the maximum Waste Volume Reduction (WVR) for the month is achieved.

- The desired WVR for each 242-A Evaporator campaign is determined by boil-down studies, computer simulation, and/or process control sampling. The concentration of waste increases after each pass through the Evaporator until it reaches a concentration level consistent with engineering studies. The waste volume projection model of the 242-A Evaporator operation used in these projections cases produced DSSF with a specific gravity of 1.41 . Upon reaching the desired concentration level, the concentrated waste is transferred to the evaporator receiver tank (Tank 106-AW). At the end of a campaign or when Tank 106-AW has been filled, DSSF is transferred to a holding tank.

- The Liquid Effluent Retention Facility (LERF) with a 13 million gallon storage capacity was used to store the evaporator process condensate until the condensate could be treated.

- The ratio of process condensate sent to LERF for every gallon of Waste Volume Reduction (WVR) for Evaporator Campaigns 94-1, 94-2, and 95-1 was $1.29,1.24$, and 1.26 , respectively (Guthrie, 1996). The average for the first three campaigns was 1.26 gallon of condensate/gallon of WVR which was the value used in this document to project future condensate production. The evaporator seal water and demister spray upgrade could reduce future process condensate production to 1.15 gallon of condensate/gallon of WVR which would lower the value used for future projections. The Effluent Treatment Facility started to process the condensate stored in LERF Basins 42 and 43 in November 1995 and processed all stored condensate by August 1996 (Wagner 1996). Since the Effluent Treatment Facility has a capacity of approximately $50 \mathrm{Mgal} / \mathrm{year}$ (Wagner, 1996), it was assumed that LERF capacity would not 1 imit future evaporator operations. 
- The maximum monthly WVR during Evaporator operation should be approximately $1500 \mathrm{kgal} / \mathrm{month}$ based on a near optimum Campaign 94-2 performance with approximately a $50 \%$ initial WVR per pass through the evaporator. (Guthrie, 1996).

- An average evaporation rate of $750 \mathrm{Kgal} / \mathrm{month}$ (Guthrie, 1996) was used in this simulation taking in to consideration:

- the 242-A Evaporator historical processing rates

- downtime between campaigns

- waste characterization

- staging and tank transfers

The simulation used in this projection evaporates all dilute wastes to a concentrated interim storage form in the same year that a tank has been filled. This assumption is valid if the evaporator is operating and the yearly waste generation rate has not exceeded the annual WVR limit of the evaporator. Historically, dilute wastes were concentrated to near the aluminate boundary which would produce concentrated wastes with a specific gravity which could range from 1.3 to 1.67 . However, it has been noted that all of the DSTs currently on the Flammable Gas Watch List (i.e., tanks with safety concerns related to hydrogen build-up) have specific gravities greater than 1.4 (Reynolds, 1994). To avoid production of future Flammable Gas Watch List tanks, it has been proposed that all future waste concentrations should be limited to a specific gravity of 1.41 unless additional technical evaluation shows flammable gas will not build-up (Fowler, 1995a and Fowler, 1995b).

The waste volume projection model of the 242-A Evaporator operation used in projections thru 1994, typically produced DSSF with a specific gravity of 1.50-1.55. Reducing these wastes to a specific gravity of 1.41 could increase waste storage volumes by approximately 22-35 percent, depending on the chemical composition of the waste. This document projected DST needs based on the evaporation of wastes to a specific gravity of 1.41 .

- The first Evaporator Campaign (94-1) started on April 15, 1994 and evaporated the wastes stored in Tanks 102-AW, 106-AW, and 103-AP. This campaign achieved approximately $2.42 \mathrm{Mgal}$ of WVR.

- The second Evaporator Campaign (94-2) started on September 22, 1994 and evaporated the wastes stored in Tanks 102-AW, 106-AW, 101-AP, 107-AP, and 108-AP. This campaign achieved approximately $2.79 \mathrm{Mgal}$ of WVR.

- The third Evaporator Campaign (95-1) started on June 8, 1995 and evaporated the wastes stored in Tanks 102-AW, 106-AW, 107-AP, and 108-AP. This campaign achieved approximately $2.16 \mathrm{Mgal}$ of WVR.

- The fourth evaporator campaign (96-1) started in May 1996 and evaporated dilute non-complexed wastes stored in Tank 104-AP (from Tanks 102-SY, 105-AW, and 102-AY). This campaign achieved 1.12 Mgal of WVR (Guthrie, 1996b).

- The fifth evaporator campaign $(97-1)$ is assumed to start in February 1997 to evaporate Tank 105-AP (dilute non-complexed waste from 
Tank 101-AN). The sixth evaporator campaign (97-2) is assumed to start in the summer of 1997 to evaporate dilute complexed waste from Tanks 101-AY and 106-AN.

- The Baseline projection assumed that evaporation capability would be available annually to evaporate all dilute wastes. The annual evaporation of dilute waste minimizes tank space requirements and allows site cleanup activities to continue unabated to allow completion of TPA milestones.

- Previous projections assumed that the 242-A Evaporator would require a 1 year outage for maintenance and or upgrades every 10 years based on a 10 year design life of the 242-A Evaporator (WHC-EP-0342). The Baseline projection assumed the 242-A Evaporator would operate thru FY 2005 with additional evaporator capability coming on line in FY 2005 to allow annual evaporations through FY 2015.

- Evaporator training runs prior to evaporator operation were estimated to add approximately $50 \mathrm{Kgal} /$ year to tank farms and $50 \mathrm{Kgal} /$ year to the LERF for evaporator certification training (Guthrie, 1996). The training run in April 1995, added $57 \mathrm{Kgal}$ to DSTs.

- Evaporator flushing after each campaign was previously projected to add $35 \mathrm{Kgal} / \mathrm{campaign}$ (Haigh, 1992). Actual flushes for the first three campaigns completed since April 1995 have varied from 27 to 58 $\mathrm{kgal} /$ campaign.

- Projected waste generations for the 242-A Evaporator due to training/flushing for $F Y 1995$ evaporator operations was $85 \mathrm{Kgal}$. For the years 1996-1999, it was estimated that 1 to 2 campaigns would be required each year based on waste generations, segregation requirements, and tank space availability. The additional operations would be needed to evaporate the anticipated increased SWL (complexed and non-complexed) and TCO wastes. Based on these considerations, the projected waste generation for the evaporator was increased to $100 \mathrm{Kgal} /$ year for the period 1996-1999. From FY 2000 on, the estimated evaporator waste generation was reduced to $85 \mathrm{Kgal} /$ year. The WVR for evaporation of these flushes to DSSF was 99 (Sederburg, 1995).

\subsection{Grout}

- No additional Grout Vaults are scheduled to be poured at the Hanford site. TWRS program planning requires that all tank wastes be separated into low-activity and high-activity fractions and each fraction be immobilized into suitable waste forms for ultimate disposal. Tanks that were originally designated and set aside as grout feed tanks were used for other purposes.

\subsection{Effluent Treatment Facility}

- A new facility called the Effluent Treatment Facility (ETF) started operation in November 1995 to process the stored evaporator condensate from the LERF, newly generated evaporator condensate, and aqueous waste water containing low specific radioactivity (Wagner, 1996). Treated 
effluent is discharged to the State Approved Land Disposal Side (SALDS), north of the 200 West Area. This site was chosen to allow tritium to decay away before the groundwater migration reaches the Columbia River. The ETF does not remove tritium because no feasible production-scale tritium removal technology presently exists. The ETF has a capacity to treat $50 \mathrm{Mgal} /$ year for future feeds. The ETF should not send any streams to DSTs.

\subsection{PFP}

The Plutonium Finishing Plant (PFP) is a facility in the 200 West Area which houses the processes and supporting operations for (Bergquist, 1996):

1) stabilization of reactive solid residues by muffle furnace calcination (OPERATIONAL);

2) shipping, receiving and storage of special nuclear materials (OPERATIONAL);

3) analytical and development laboratories (OPERATIONAL);

4) treatment and handling of PFP liquid wastes destined for tank farms and the ETF (OPERATIONAL).

An Environmental Impact Statement (EIS) was issued for public comment in November 1995 covering the PFP facility stabilization and clean out. Since the record of decision is not expected until late in FY 1996, the waste volume projection for PFP was based on the preferred alternative identified in the EIS for facility cleanout and stabilization. The volume of waste anticipated to be produced for the Baseline Case is developed from the existing waste generation rate at PFP (100 untreated gallons/month), and the anticipated use of a direct denitration vertical calciner coupled with an ion exchange pretreatment system currently being developed and tested by the development laboratories. The vertical calciner (Bergquist, 1996) is the most promising technology for plutonium residue stabilization and facility clean out. The Baseline Case would generate a total of $30 \mathrm{Kgal}$ of waste from 1996 through 2006 (Bergquist, 1996). The WVRF to evaporate PFP wastes to DSSF is 81 (Sederburg, 1995). Flush volumes for PFP stabilization waste streams is 22 per cent (flushes of waste transfer lines from PFP to 244-TX and from 244-TX to Tank 102-SY).

Although the waste generations used for the Lower and Upper Planning Cases were the same as those used for the Baseline Case, generation volume for PFP stabilization could run as high as $36 \mathrm{Kgal}$ for other stabilization methods (Bergquist, 1996). The percent solids experienced in past PFP waste generations are listed below (Barrington, 1991):

$\begin{array}{ll}\% \text { Solids in PRF waste } & 3.5 \% \\ \% \text { Solids in RMC waste } & 4.4 \% \\ \% \text { Solids in lab waste } & 4.5 \%\end{array}$

\subsection{PUREX}

The Plutonium Uranium Extraction (PUREX) Facility was used to separate irradiated $N$ Reactor fuel into plutonium nitrate, uranyl nitrate hexahydrate (UNH), neptunium nitrate, and waste products. The main processing operations involved dissolution of cladding and irradiated fuel, solvent extraction and 
conversion of plutonium nitrate to plutonium oxide. Acid recovery, solvent treatment systems, and off-gas treatment supported the major processes.

Westinghouse Hanford Company has been directed by the Department of Energy (DOE) to proceed with deactivation of PUREX. A detailed plan for the deactivation of the PUREX facility was completed in the fourth quarter of $F Y$ 1993. Deactivation of PUREX started in April 1994 and will continue through FY 1997 (Ethington, 1996) with most of the waste being sent to DSTs by the end of FY 1996. It is assumed that all waste transfers from PUREX to the DST system will cease once deactivation has been completed.

The amount of waste remaining to be transferred from PUREX to the DSTs for a11 three projection cases was projected to be $45 \mathrm{Kgal}$ of low level non-dangerous waste (Ethington, 1996). Based on the average waste composition presented for PUREX TCO wastes, the WVRF for evaporation of PUREX TCO wastes to DSSF is 99 (Sederburg, 1995). Flush volumes for PUREX TCO waste streams is 10 per cent.

\section{$3.7 \quad$ S_Plant}

S Plant (or 222-S Labs) is a dedicated laboratory facility. The Laboratory currently provides analytical chemistry services in support of Westinghouse Hanford Company's processing plants and tank characterization. Emphasis is on waste management processing plants, environmental monitoring programs, $B$ Plant, Tank Farms, 242-A Evaporator, Waste Encapsulation Storage Facility (WESF), PUREX Facility, Plutonium Finishing Plant (PFP), research support activities, and essential materials. Most of the radioactive liquid waste generated at the laboratory complex originates from analytical activities performed within the 222-S Laboratory in support of tank characterization (Collins, 1996). Radioactive and radioactive hazardous (mixed) wastes generated by the 222-S Laboratory are discharged to the 219-S Waste Handling Facility. Dilute, non-complexed wastes are currently being transported to 204-AR vault via tanker truck. Projected S Plant monthly waste generations rates (Collins, 1996) were approximately $8 \mathrm{Kgal} /$ month for FY 1996 and 10 $\mathrm{Kgal} /$ month for FY 1997 through 2028 for the Baseline Case. All three projection cases used the same waste generation rates. Based on the waste composition presented for 222-S Laboratory wastes, the WVRF for evaporation of 222-S miscellaneous wastes to DSSF is 99 (Sederburg, 1995). Flush volumes for 222-S waste streams is 22 per cent.

\subsection{Salt Well Liquid Pumping}

Salt Wel1 Liquid (SWL) pumping will occur for single-shell tanks (SSTs) which have 50,000 gallons or more of drainable interstitial liquid. Pumping is scheduled to stop when the output rate decreases to 0.05 gallons per minute. SWL pumping assumptions for afl three projection cases are listed below:

- The Baseline Case used a 50 percent saltcake porosity/21 percent sludge porosity resulting in a remaining volume of $5.57 \mathrm{mi}$ lition galions (Brown, 1996) of SWL to be pumped from FY 1996 through the end of FY 1999 to meet TPA milestone M-41-00 (volume for Tank 106-C included with single shell tank solids retrieval). The schedule for SWL pumping (Saueressig, 1996) delays pumping of complexed SWL and flammable gas tank wastes in 200 W Area until FY 1998. The WVRF for evaporation of non-complexed SWL 
to DSSF is 47 (Sederburg, 1995). The WVRF for evaporation of complexed SWL to Complexant Concentrate (CC) is 10 (Sederburg, 1995).

- Flushing of the salt well 1 iquid and transfer 1 ines will generate approximately 1.45 Mgal (26 percent) of water (Brown, 1996). The WVRF used for this flush is 99 (Sederburg, 1995).

- Approximately $1.75 \mathrm{Mgal}$ (31 percent) of the total SWL volume is complexed based on available analytical information.

- The pumping schedule for the Baseline Case is presented in Table 3 based on the March 5, 1996 Draft Interim Stabilization Tri-Party Agreement M41-00 Recovery Plan (Saueressig, 1996). Total volumes were taken from Brown (1996) at $50 \%$ saltcake porosity $/ 21 \%$ sludge porosity.

Table 3. Salt Well Pumping Schedule for the Baseline Case

\begin{tabular}{|c|c|c|c|c|c|}
\hline \multicolumn{3}{|c|}{$\begin{array}{l}\text { Salt Well Pumping Schedule for } \\
\text { (Brown, 1996) }\end{array}$} & \multicolumn{3}{|c|}{$50 \%$ Saltcake/21\% S1udge Porosits } \\
\hline \multirow{2}{*}{$\begin{array}{l}\text { FISCAL } \\
\text { YEAR }\end{array}$} & \multicolumn{2}{|c|}{ EAST AREA } & \multicolumn{2}{|c|}{ WEST AREA } & \multirow[t]{2}{*}{ TOTALS } \\
\hline & DN & $D C$ & DN & $\mathrm{DC}$ & \\
\hline 1989 & $55 \mathrm{KGAL}$ & $0 \mathrm{KGAL}$ & $0 \mathrm{KGAL}$ & $17 \mathrm{KGAL}$ & $72 \mathrm{KGAL}$ \\
\hline 1990 & $44 \mathrm{KGAL}$ & $0 \mathrm{KGAL}$ & $0 \mathrm{KGAL}$ & $0 \mathrm{KGAL}$ & $44 \mathrm{KGAL}$ \\
\hline 1991 & $227 \mathrm{KGAL}$ & $0 \mathrm{KGAL}$ & $0 \mathrm{KGAL}$ & $0 \mathrm{KGAL}$ & $227 \mathrm{KGAL}$ \\
\hline 1992 & $121 \mathrm{KGAL}$ & $0 \mathrm{KGAL}$ & $0 \mathrm{KGAL}$ & $0 \mathrm{KGAL}$ & $121 \mathrm{KGAL}$ \\
\hline 1993 & $0 \mathrm{KGAL}$ & $0 \mathrm{KGAL}$ & $37 \mathrm{KGAL}$ & $0 \mathrm{KGAL}$ & $37 \mathrm{KGAL}$ \\
\hline 1994 & $189 \mathrm{KGAL}$ & $0 \mathrm{KGAL}$ & $32 \mathrm{KGAL}$ & $0 \mathrm{KGAL}$ & $221 \mathrm{KGAL}$ \\
\hline 1995 & $194 \mathrm{KGAL}$ & $105 \mathrm{KGAL}$ & $18 \mathrm{KGAL}$ & $0 \mathrm{KGAL}$ & $317 \mathrm{KGAL}$ \\
\hline 1996 & $4 \mathrm{KGAL}$ & $0 \mathrm{KGAL}$ & $272 \mathrm{KGAL}$ & $0 \mathrm{KGAL}$ & $276 \mathrm{KGAL}$ \\
\hline 1997 & $255 \mathrm{KGAL}$ & $494 \mathrm{KGAL}$ & $1399 \mathrm{KGAL}$ & $0 \mathrm{KGAL}$ & $2148 \mathrm{KGAL}$ \\
\hline 1998 & $133 \mathrm{KGAL}$ & $395 \mathrm{KGAL}$ & $1265 \mathrm{KGAL}$ & $530 \mathrm{KGAL}$ & $2323 \mathrm{KGAL}$ \\
\hline 1999 & $0 \mathrm{KGAL}$ & $23 \mathrm{KGAL}$ & 432 KGAL & $317 \mathrm{KGAL}$ & $772 \mathrm{KGAL}$ \\
\hline 2000 & $0 \mathrm{KGAL}$ & $0 \mathrm{KGAL}$ & $0 \mathrm{KGAL}$ & $0 \mathrm{KGAL}$ & $0 \mathrm{KGAL}$ \\
\hline TOTALS & $1222 \mathrm{KGAL}$ & $1017 \mathrm{KGAL}$ & $3455 \mathrm{KGAL}$ & $864 \mathrm{KGAL}$ & $6558 \mathrm{KGAL}$ \\
\hline
\end{tabular}

o Total Amount of SWL to be pumped from FY 1996-1999 for the Baseline Case is approximately $5.57 \mathrm{Mgal}$ without flush.

- Tank 101-AN was designated as the East Area dilute non-complexed SWL receiver tank.

- Tank 101-AY is currently designated as the East Area complexed SWL receiver tank. This projection assumed that the contents of Tank 101-AY were pumped to Tank 108-AP in late FY 1996 to allow Tank 101-AY to be 
WHC-SD-WM-ER-029 Rev. 22

used for in-tank washing. Tank 108-AP would be the future receiver for East Area Complexed SWL.

- Pumping SWL in West Area presents special problems due both to the limited tank space available and due to the transuranic (TRU) heel in Tank 102-SY. Tanks 101-SY and 103-SY contain complexed waste and are also designated as Watch List Tanks. Addition of waste to watch List tanks is prohibited unless a safer alternative cannot be found.

Therefore, Tank 102-SY was designated as the West Area SWL receiver for both non-complexed and complexed SWL starting in FY 1998. Tank 102-SY contains approximately $133 \mathrm{Kgal}$ of TRU solids (Table 8) that are not scheduled to be retrieved until 12/1998 (Barton, 1996). Historically, complexed waste and TRU wastes have been segregated to minimize the amount of waste requiring more expensive disposal and to comply with U.S. Department of Energy (DOE) Order 5820.2A. The Hanford Site has implemented this order by segregating waste that was considered complexed (greater than 10 grams/liter total organic carbon) from TRU waste sludge (Reynolds, 1995). The schedule presented in Table 3 would require pumping complexed SWL over the sludge in Tank 102-SY in order to meet TPA milestones for the years 1998-1999. Studies are being conducted to resolve this issue and to determine exactly how much of the waste in the 200 West Area are complexed (Estey, 1996). Some options include--delaying complexed SWL pumping in West Area until Tank 102-SY solids are retrieved; accelerating the retrieval of the TRU solids from Tank 102-SY; dilution and retrieval of the waste from either Tank 101-SY or 103-SY to free up additional tank space; conduct experiments to prove the complexed SWL can be added to the TRU solids in Tank 102-SY without solubilizing the TRU; or use a DCRT to pump complexed SWL to East Area without sending the waste to Tank 102-SY. In this projection, the complexed wastes are shown being pumped to Tank 102-SY to meet the revised TPA schedule (Saueressig, 1996).

\subsection{Single-Shell Tank Solids Retrieval}

- The TPA start date for retrieval of Tank 106-C (M-45-03A) is 0ctober 1997 but this projection assumed that the start date for retrieval of Tank 106-C would be October 1996 to satisfy Safety Initiative 6e (Wang, 1994 and Grumbly, 1993). Retrieval of Tank 106-C solids will require approximately a 3:1 ratio of dilution water to solids (Estey, 1994). Solids retrieved from Tank $106-\mathrm{C}$ will be stored in Tank 102-AY.

- Approximately 12.2 Mgal of sludge and $23.4 \mathrm{Mgal}$ of saltcake will be retrieved from SSTs (Hanlon, 1995). Dilution of these solids for retrieval and pretreatment results in a total of approximately $139 \mathrm{Mgal}$ (She1ton, 1995).

- Retrieval of the remaining solids from all 149 SSTs will begin in December 2003 (M-45-03-T1) and be completed by the end of FY 2018. Saltcake will be diluted to $5 \mathrm{M} \mathrm{Na}$ and sludge will be diluted to 10 weight percent solids. Approximately a $3: 1$ ratio of dilution water to solids will be required for the retrieval of the remaining SST solids. It is further assumed that all solids will be removed from the SSTs and that SST site closure will be complete by FY 2024 (M-45-06). 
- The retrieval schedule for SST solids for all three projection cases was based on Case P21B of the TWRS Disposal Program assumptions (Washenfelder, 1996a) with $0.7 \mathrm{Mgal}$ of the retrieved waste volume shifted from 2004 to 2005. (Note: A different schedule was received too late to be included in these projection cases (Washenfelder, 1996b)). Approximately $2.8 \mathrm{Mgal}$ (retrieved volume) of wastes would be retrieved during the period 2004-2005 beginning with Tanks 103-AX, 103-C, 102-A, and $105-C$. The as retrieved volumes for the remaining SST solids are shown in the spreadsheet for the Baseline Case (Section 5.1) and are based on retrieval at $5 \mathrm{M} \mathrm{Na}$. It was assumed that the as retrieved SST wastes would be concentrated to $7 \mathrm{M} \mathrm{Na}$ for storage purposes which increases evaporation needs during the period 2004-2015 (Washenfelder, 1996b).

\subsection{Solid Waste Trench 31 Leachate}

A leachate collected from the mixed waste 1 andfill (Trench 31). The maximum daily leachate volume is estimated to be 110,000 gallons from the 24 hour $/ 25$ year precipitation event (McKenney, 1994). There is only a remote chance that this waste stream will be transferred to DSTs and this stream has not been included in any of the three projection cases.

\section{$\underline{3.11 \mathrm{~T} \text { Plant }}$}

$T$ Plant's primary mission is decontamination and treatment of radiologically and chemically contaminated waste and equipment located throughout the Hanford site (Triner, 1996). T Plant also provides inspection and repackaging services to various Hanford facilities and the certification (hydrostatic leak testing) of the railcars used to transport liquid wastes to Tank Farms. New railcars are being procured which will eliminate the need for hydrostatic leak testing and the projected waste volumes reflect this decrease. The 2706-T Low-Level Decontamination Facility (where low-level equipment decontamination is performed) is an approved decontamination facility that commenced operation in September 1994. Limited 221-T canyon decontamination activities (primarily Tank Farms long-length contaminated equipment) were initiated in 1995 .

T Plant is currentiy testing new decontamination techniques (ice blasting and $\mathrm{CO}_{2}$ decontamination systems) which have reduced liquid waste generations from those reported previously. Dilute, non-complexed wastes collected at T Plant during decontamination, repackaging, condensate collection, or railcar certification are currently being transported to 204-AR vault via railcar. These wastes contain approximately $5 \%$ solids (Triner, 1996). Projected T Plant monthly waste generations (Triner, 1996) were based on a combination of anticipated work loads and actual observed generation rates. The projected volumes supplied by T Plant engineers decreased from $3.6 \mathrm{Kgal} / \mathrm{month}$ in $\mathrm{FY} 1996$ to $2.5 \mathrm{Kgal} /$ month in FY 2028 (waste volume generations for each year are shown in the spreadsheet for the Basel ine Case--Section 5.1). Al1 three projection cases used the same generation rates. The WVRF for evaporation of T Plant miscellaneous wastes to DSSF is 99 (Sederburg, 1995). Flush volumes for T Plant waste streams is 22 per cent. 


\subsection{Tank Farms}

There are currently 28 double-shell tanks (DSTs) used to receive, store, and evaporate the liquid wastes generated at the Hanford facilities to an interim waste form. The interim waste form (e.g., DSSF) is currently stored in tank farms awaiting pretreatment and vitrification for final disposal. Tank farm waste generation sources and operational considerations are listed below for the aging and non-aging waste tanks. Tank Farm waste generations are primarily from line, cross-site, and air-lift circulator flushes.

\section{Aging Double-She11 Tanks}

Four of the DSTs ( $A Y$ and $A Z$ farms) are designated as aging waste tanks that were designed to store high-heat wastes (e.g., NCAW wastes or wastes containing high-heat loads due to the presence of ${ }^{90} \mathrm{Sr}$ or $\left.{ }^{137} \mathrm{Cs}\right)$. The aging waste tanks are equipped with condensers and air-lift circulators. The purpose of the condensers is to handle the vapors from primary tank vent systems when hot liquid is present. Condensates are collected in catch tanks (e.g., 151-AZ, 152-AX, or TK-417) and returned either to an aging waste tank or to a dilute receiver tank. The air-lift circulators aid in suspending NCAW solids and in heat removal. Air-lift circulators require periodic flushing to prevent clogging.

Aging waste tank operation assumptions used in all three projections follow:

- Aging waste tanks can be used for storage of diTute non-aging waste.

- It is assumed that there will be no additional aging waste produced by the Hanford facilities. However, certain wastes containing high ${ }^{90} \mathrm{Sr}$ or ${ }^{137} \mathrm{Cs}$ contents may require storage in aging waste tanks due to their radioactivity.

o Single-shell tank (SST) solids retrieved from Tank $106-C$ will be stored in an aging DST (Tank 102-AY) due to the high heat contents of the solids.

o One million gallons of aging tank space is kept available for receiving the contents of an aging waste tank, in the unlikely event of a tank leak (Department of Energy order 5820.2A).

- Tank 102-AY was designated as the 200 East Area dilute receiver for noncomplexed wastes through mid FY 1996 and then Tank 106-AP was designated as the 200 East Area dilute receiver. This change allowed Tank 102-AY to be used to store the solids retrieved from Tank 106-C in FY 1997. Tank 106-AP is currently receiving direct transfers of wastes from $B$ Plant and rail or truck shipments via 204-AR vault from S Plant, $T$ Plant, 100 Area, 300 Area, and 400 Area.

\section{Non-Aging Double-She11 Tanks}

The remaining 24 DSTs are called non-aging waste tanks and are used to store wastes that do not contain high-heat loads in accordance with applicable 
operational and waste segregation policies. Non-aging waste tank operation assumptions are as follows:

- Approximately $66 \mathrm{Kgal}$ of caustic will be added to Tank 107-AN in FY 1997 to mitigate the low caustic condition in the tank for all projection cases (Carothers, 1996a and 1996b).

- Operational tank usage for this projection are summarized in Table 4.

o Starting in FY $1999,0.72 \mathrm{Mgal}$ of operational space in the evaporator Feed and Receipt Tanks (Tanks 102-AW and 106-AW) was used as spare space (Awada17a, 1995) in all three projection cases.

0 It was assumed that the TRU solids in Tank 102-SY would be retrieved to Tank 105-AW starting in December 1998 (Barton, 1996). The NCRW solids in Tank 105-AW were not combined with the solids in Tank 103-AW in this projection.

Table 4. Operational Tanks and Usage

\begin{tabular}{|l|l||}
\hline \multicolumn{1}{|c|}{ Operation } & \multicolumn{1}{|c|}{ Designated Tank } \\
\hline \hline Evaporator Feed Tank & Tank 102-AW (modeled as a ful1 tank) \\
\hline Evaporator Receiver Tank & Tank 106-AW (tank 1evel varies) \\
\hline Dilute Receiver Tank & Tank 105-AW (PUREX direct transfers) \\
\hline Dilute Receiver Tank & Tank 106-AP (1996-1999) \\
\hline 200 East SWL Receiver (DN) & Tank 101-AN \\
\hline 200 East SWL Receiver (DC) & Tank 108-AP \\
\hline 200 West SWL Receiver (DN) & Tank 102-SY \\
\hline 200 West SWL Receiver (DC) & Tank 102-SY \\
\hline Private Contractor Feed Tanks & Tanks 106-AP and 108-AP \\
\hline Intermediate Staging Tanks & Tanks 102-AP and 106-AP \\
\hline $\begin{array}{l}\text { Sr/TRU/Entrained Solids } \\
\text { Return Waste }\end{array}$ & Tank 102-AZ (6/2002-mid FY 2003) \\
\hline $\begin{array}{l}\text { Sr/TRU/Entrained Solids } \\
\text { Return Waste }\end{array}$ & Tank 101-AZ (mid FY 2003-2015) \\
\hline \begin{tabular}{l} 
Spare Tank Space \\
\hline
\end{tabular} & Tank 103-AP (1996-1998) \\
\hline
\end{tabular}

- Flushes are generated during the receipt of waste transfers either from railroad tank cars, tanker trucks, or after tank to tank transfers. Percent flushes are included with a description of each of the facility generations in Section 3 .

- Some proposed tank usage changes were received too late to incorporate in these projections. These changes for the 200 East Area would include 
the use of Tank 101-AN as the complexed SWL receiver and use of Tank 106-AP as the non-complexed SWL receiver (Hanson, 1996).

Projected waste generations for Tank Farms were based on a combination of previously observed waste generation rates and anticipated operational needs that are explained below:

- Tank Farm water additions to DSTs. Tank Farms waste generation rates and flushing activities general1y increase with the restart of the 242-A Evaporator due to the additional waste transfers. The 242-A Evaporator was restarted in April 1994. During the period April 1994 through May 1995 , the average monthly waste generation rate for Tank Farms was 10.92 $\mathrm{Kgal} / \mathrm{month}$. The average monthly waste generation for Tank Farms during FY 1996 was $77.3 \mathrm{kgal} /$ month. The target rate set for Tank Farms waste generations was $10 \mathrm{Kgal} /$ month. All three projection cases estimated that Tank Farms would generate $10 \mathrm{Kgal} / \mathrm{month}$ or $120 \mathrm{Kgal} /$ year to cover transfer line and air-lift circulator flushes. The WVR for evaporation of these flushes to DSSF was 99 (Sederburg, 1995).

- Cross-site Transfers. All projection cases assumed that either the existing cross-site transfer 1 ine or the new cross-site transfer 1 ine (Project $W-058$, scheduled to be completed in 1998) would be available to allow cross-site transfer of SWL, facility generations, DST solids from Tank 102-SY and/or SST solids. Without operable cross-site lines many of the TPA milestones involving West area wastes could not be achieved.

Previous projections have estimated that $50 \mathrm{Kgal}$ of water ( $35 \mathrm{Kgal}$ testing $+20 \mathrm{Kgal}$ for transfer) would be needed for cross-site transfers. In this projection the water addition for cross-sites was reduced to $35 \mathrm{Kgal} /$ transfer due to waste minimization actions defined for the FY 1995 transfer. During the period 1997-1999, approximately two cross-sites would be needed each year due either to the volume of SWL being pumped or to the pumping of non-complexed and complexed SWL through Tank 102-SY during the same year. Based on the projected crosssite testing and transfers anticipated, $70 \mathrm{Kgal} /$ year was projected for the period FY 1996-2015. A11 three projection cases used the same volumes for cross-site transfer line tests and flushes. The WVR for evaporation of these flushes to DSSF was 99 (Sederburg, 1995).

o Tank Fill Limits (except for special tank fill considerations):

- AY, AZ Tanks: $980 \mathrm{Kgals}$

- All other DSTs: $1140 \mathrm{Kgals}$

- The assumptions used to simulate tank transfers in this projection are listed below:

- Tank 102-SY: $879 \mathrm{Kgal}$ in the tank, and PRF not operating, pumped down to $50 \mathrm{Kgal}$ above solids.

- Tank 102-AY: Start transfer at $900 \mathrm{Kgal}$.

- Tank 105-AW and other dilute receivers: Start transfer at $1000 \mathrm{Kgal}$, pump down to $50 \mathrm{Kgal}$ above solids. 


\section{$\underline{3.13 \mathrm{UO}_{3} \text { Facility }}$}

The $\mathrm{UO}_{3} \mathrm{Facility}$ concentrated and calcined uranyl nitrate hexahydrate (UNH) recovered by the PUREX plant to produce uranium oxide $\left(\mathrm{UO}_{3}\right)$ and nitric acid $\left(\mathrm{HNO}_{3}\right)$. Until now, the $\mathrm{UO}_{3} \mathrm{Facility}$ has not produced any DST wastes. Rainwater collected at the facility will be sent to cribs.

\subsection{Waste Sampling and Characterization Facility (WSCF)}

The Waste Sampling and Characterization Facility (WSCF) was started in FY 1994. This projection assumed that WSCF would send its waste to ETF and not to DSTs (Coltins, 1996).

\section{$\underline{3.15} 100$ Area}

\section{$100-\mathrm{N}$ Basin}

The 100-N Basin was constructed in 1963 to receive irradiated fuel assemblies discharged from the $N$ Reactor for the purpose of inspection, storage, and preparation for shipment. In 1988 the $\mathrm{N}$ Reactor was placed in a "cold standby" status (shutdown but capable of restarting). In 1989 all nuclear fuel was removed from $N$ Basin and transferred to K Basin. In 1991 the Department of Energy-Richland (DOE-RL) directed Westinghouse to begin deactivation activities. A significant quantity of radioactively contaminated equipment, hardware, debris, and sediment have accumulated in $100-\mathrm{N}$ Basin that will need to be removed. Deactivation of the $\mathrm{N}$ Basin Facility will occur over the period FY 1996 through 1997. For the Baseline Case, it was assumed that $N$ Basin water and Emergency Dump Basin water would be transferred to ETF for processing (Greenidge, 1996). Approximately 524 gallons of sediment would be slurried in 13,000 gallons of North Cask Pit residual water and transferred to DSTs in FY 1997. The same waste generation volume was used for all three cases.

\section{$100-\mathrm{K}$ Basin}

Fuel handling operations have resulted in some cladding damage to $\mathrm{N}$-Reactor fuel. Subsequent fuel oxidation resulted in fuel and fission products accumulating in fuel canisters and in $\mathrm{K}$ Basin where the fuel handling occurred. Aluminum oxide, iron oxide, concrete grit, and other debris has accumulated and mixed with the fuel corrosion products to form a sludge on the basin floor. Approximately $350 \mathrm{Kgal}$ of water and sediment (approximately 18.5 Kgal of sediment) would be transferred to DSTs (Alderman, 1996). Transfers would occur on a monthly basis over a four year period (1997-2000). The above generations for 100-K Basin cleanout were used in all three projection cases. (Late Note: Generations from 100-K Basin could be delayed until 1999 and be received on a weekly basis).

105-F \& 105-H Basins

Plans to cleanout the $105-\mathrm{F}$ and $105-\mathrm{H}$ Basins are still being reviewed and the date of cleanout is uncertain due to funding. The projected plan is to clean out the 40,000 gallons in $105-F$ in the year 2000 and the 200,000 gallons from $105-\mathrm{H}$ in the year 2003 (Griffin, 1996). These assumptions for 105- $\mathrm{F}$ and $105-\mathrm{H}$ Basin cleanout were used for all three projection cases.

The WVRF for evaporation of all 100 Area Basin wastes to DSSF is 99 (Sederburg, 1995). Flush volumes for 100 Area wastes is 44 per cent. 


\subsection{Area}

Facilities in the 300 Area are used primarily for research and development activities or for analytical support. Some waste received in FY 1995 was generated by decon of facilities. Liquid wastes from the various 300 Area Facilities are transferred to the 340 Facility. Liquid wastes collected at the 340 Facility are transferred to $204-A R$ vault in 20,000 gallon railroad tank cars. Facilities in the 300 Area sent $58 \mathrm{kgal}$ of waste to DSTs (4.8 $\mathrm{Kgal} / \mathrm{month}$ ) in FY 1995. The Basel ine Case projected $4.5 \mathrm{Kgal} / \mathrm{month}$ of miscellaneous waste would be generated from 300 Area facilities (Halgren, 1995b). All three projection cases used the same generation rates. Based on the chemical composition supplied for 300 Area waste streams (Halgren, 1995a), the WVRF for evaporation of 300 Area miscellaneous wastes to DSSF is 94 (Sederburg, 1995). Flush volume for 300 Area waste streams is 44 per cent.

\subsection{Area}

There are three major facilities in the 400 Area (Miller, 1996). These include the Fast Flux Test Facility (FFTF), the Maintenance and Storage Facility (MASF), and the Fuel and Material Examination Facility (FMEF). Radioactive liquid waste is primarily generated in conjunction with the removal of residual sodium from reactor components or with decontamination activities. A phased process was begun in December 1993 to place the FFTF into a radiologically and industrially safe shutdown condition. Shutdown of the FFTF has increased the amount of liquid waste generated by the plant's Sodium Removal System. Approximately $11 \mathrm{Kgal}$ of wastes were received from 400 Area in FY $1994-1995$ ( $0.5 \mathrm{Kgal} /$ month). The Baseline Case projected 0.5 $\mathrm{Kgal} / \mathrm{month}$ of miscellaneous waste would be generated from 400 Area facilities. Al1 three projection cases used the same generation rates. The WVRF for evaporation of 400 Area miscellaneous wastes to DSSF is 94 (Sederburg, 1995). Flush volume for 300 Area waste streams is 44 per cent.

\subsection{Phase I Privatization Processing}

- Privatization Concept. The revised DOE strategy for treatment of Hanford tank wastes, termed "privatization," would use private contractors to design, permit, build, operate, and decommission the facilities for waste treatment and immobilization (DOE, 1995). Final details of the privatization work will not be developed until later in the process and the assumptions listed below are subject to change. As currently proposed, privatization would be divided into two phases. Phase I would include privatization of waste tank supernatant pretreatment, Low-Activity Waste (LAW) immobilization, and an optional High-Level Waste (HLW) immobilization (Washenfelder, 1996b) by two private contractors. The scale of processing during Phase I of privatization has been established to demonstrate the technical and commercial capability. Phase II of privatization would include additional tank waste retrieval, supernatant pretreatment, sludge/solid pretreatment, LAW immobilization, HLW immobilization, disposition of encapsulated $\mathrm{Cs} / \mathrm{Sr}$, and interim storage of immobilized waste (Washenfelder, 1996b). 
0 Phase I Schedule. The target schedule for Phase I is summarized below and may slightly exceed TPA dates:

-Contract Award for Phase 1 A

-Start construction

-operations

August 31,1996

December 31,1999

June 1, 2002-June 1, 2011

0 Waste Staging Tanks. It was assumed that Tanks 106-AP and 108-AP would be transferred to the two private contractors in FY 2000 . At the time these tanks were transferred to the private contractors they were filled with the initial feed to be processed in Phase $I$.

Tanks 102-AP and 104-AP were used for intermediate staging of wastes by the Project Hanford Management Contractor(PHMC). Wastes from Tanks 102AP and 104-AP were transferred to Tanks 106-AP and 108-AP, respectively, approximately one month before the scheduled pretreatment date.

Intermediate feed staging requires that Tanks 102-AP and 104-AP are then immediately refilled with the next scheduled batch of feed. A nominal 10 days are allocated for setup and transfer of feed to the intermediate feed staging tanks - this is small enough to be modeled with an immediate refill (Certa, 1996).

o HLW Pretreatment and Immobilization. Phase I processing of tank waste sludges would be conducted within existing DSTs and would involve sludges in Tanks 101-AZ, 102-AZ, 102-AY, and the high heat solids retrieved from single-shell tank 106-C. In Revision 21 of this document, it was assumed that all NCAW solids and the $106-C$ solids would be combined into one aging waste tank (Tank 102-AZ) and that a 11 NCAW supernates would be concentrated into one aging waste tank (Tank 101$A Z$ ). Since that document was published, studies have been completed which looked at numerous sludge washing/combination options (Powell, 1996a and 1996b). The alternatives for consolidating high heat sludges have been reviewed by a decision board comprised of WHC management, a DOE/RL representative, and a WDOE representative. It was conc 7 uded that consolidating all the sludges into a single tank would require modifications to the tank farm safety basis. The preliminary decision reached was not to consolidate all the high heat sludges into a single tank. The selected alternative (Alternative 8 Modified) would wash the sludges in the tanks they reside in without additional consolidation of solids. The NCAW supernates could not be combined into a single aging tank (Tank 101-AY) due to the $5 \mathrm{M} \mathrm{Na}$ limit but would be concentrated and sent to Tank 101-AY and an additional non-aging tank (Powe11, 1996b). The in-tank washing assumptions summarized in Table 5 and presented below are preliminary and subject to change in future revisions of this document.

In-Tank Washing of Tank 101-AZ Siudge

- The first step of in-tank washing for all three projection cases involved the decanting of supernatant from Tank 101-AZ to Tank 101-AY (contents of Tank 101-AY previously transferred to AP Farm) in FY 1997 (Washenfelder, 1996b). The decanted aging waste supernate from Tank 101-AZ would require storage in an aging waste tank due to its heat content. 
- Approximately 280,000 gallons of wash solution (0.1 M sodium hydroxide, $0.011 \mathrm{M}$ sodium nitrate) is added in November 1997. The solids are mobilized with mixer pumps, settled for one month, and the wash is decanted in January 1998 to a non-aging DST.

o The washed NCAW solids would then be sampled to determine the effectiveness of the washing process. Finally, approximately 160,000 gallons of solution ( $0.1 \mathrm{M}$ sodium hydroxide, $0.011 \mathrm{M}$ sodium nitrate) would be added to the washed NCAW solids in May 1998. This solution would be used to mix and transfer the washed solids to the private contractors for disposal during the period June 2002 through January 2003.

\section{In-Tank Washing of Tank 102-AZ Sludge}

0 The supernatant from Tank 102-AZ is concentrated in-tank and then decanted in October 2000. A portion of this supernatant would go to Tank 101-AY with the remainder going to non-aging DSTs. Due to questions about the allowable final $\mathrm{Na}$ concentration and the amount of heat in the supernatant, storage of the remaining supernatant could require one or two additional DSTs (Powe11, 1996a and 1996b). The projection cases assumed this supernatant would be stored in Tank 101-AY plus one additional non-aging DST.

- Approximately 230,000 gallons of wash solution $10.1 \mathrm{M}$ sodium hydroxide, $0.011 \mathrm{M}$ sodium nitrate) is added in November 2000. The solids are mobilized with mixer pumps, settled for one month, and the wash is decanted in January 2001 to a non-aging DST. This washing process is repeated again in the period February to April 2001 with the addition of 160,000 gallons of wash solution.

- The washed NCAW solids would then be sampled to determine the effectiveness of the washing process. Finally, approximately 130,000 gallons of solution $(0.1 \mathrm{M}$ sodium hydroxide, $0.011 \mathrm{M}$ sodium nitrate) would be added to the washed NCAW solids in May 2001. This solution would be used to mix and transfer the washed solids to the private contractors for disposal during the period August 2003 to January 2005.

\section{In-Tank Washing of Tank 102-AY/Tank 106-C Sludges}

- The supernatant from Tank 102-AY is decanted from Tank 102-AY in 0ctober 2003. This supernatant would be transferred to a non-aging DST for further evaporation.

- Approximately 320,000 gallons of wash solution $0.1 \mathrm{M}$ sodium hydroxide, $0.011 \mathrm{M}$ sodium nitrate) is added in November 2003. The solids are mobilized with mixer pumps, settled for one month, and the wash is decanted in January 2004 to a non-aging DST. This washing process is repeated again during the period November 2003 through May 2004.

- The washed NCAW solids would then be sampled to determine the effectiveness of the washing process. Finally, approximately 320,000 gallons of solution $(0.1 \mathrm{M}$ sodium hydroxide, $0.011 \mathrm{M}$ sodium nitrate) would be added to the washed NCAW solids in June 2004. This solution would be used to mix and transfer the washed solids to the private 
contractors for disposal during the period June 2005 through February 2008.

- Al1 three projection cases assumed that approximately 340 metric tons of high-level waste oxides would be transferred to the vendor for immobilization during the period June 2002 through June 2008. It was assumed that this action would process all solids from Tanks 101-AZ, 102-AZ, 102-AY, and 106-C. The private contractor would provide a tank for receipt of the washed sludges; existing DSTs would not be used for these functions (Washenfelder, 1996b).

$0 \quad$ In-tank washing activities and waste work-off for the modified alternative 8 case are summarized in the following table.

Table 5. Summary of In-Tank Washing Activities (Modified Alternative 8 )

\begin{tabular}{|l||l||}
\hline Date & In-Tank Washing Activity \\
\hline \hline Sept. 1997 & $\begin{array}{l}\text { Complete retrieval of Tank 106-C solids into } \\
\text { Tank 102-AY. }\end{array}$ \\
\hline Oct. 1997 & $\begin{array}{l}\text { Decant the NCAW supernate from Tank 101-AZ to } \\
\text { Tank 101-AY. }\end{array}$ \\
\hline Nov. 1997-Apri1 1998 & Wash NCAW solids in Tank 101-AZ twice. \\
\hline May 1998 & Sample Tank 101-AZ solids and cover with 1iquid. \\
\hline Oct. 2000 & $\begin{array}{l}\text { Decant Tank 102-AZ supernatant to Tank 101-AY and two } \\
\text { other non-aging DSTs. }\end{array}$ \\
\hline Nov. 2000-Apri1 2001 & Wash NCAW solids in Tank 102-AZ twice. \\
\hline May 2001 & Sample Tank 102-AZ solids and cover with liquid. \\
\hline June 2002-Jan. 2003 & Transfer Tank 101-AZ solids to contractors. \\
\hline Aug. 2003-Jan. 2005 & Transfer Tank 102-AZ solids to contractors. \\
\hline Oct. 2003 & Decant supernatant from tank 102-AY to a non-aging DST. \\
\hline Nov. 2003-May 2004 & $\begin{array}{l}\text { Wash solids in Tank 102-AY (existing solids plus } \\
\text { Tank 106-C solids) twice. }\end{array}$ \\
\hline June 2004 & Sample Tank 102-AY solids and cover with liquid. \\
\hline June 2005-Feb. 2008 & Transfer Tank 102-AY solids to contractors \\
\hline \hline
\end{tabular}

- Low-Activity Waste (LAW) Treatment. The current DOE strategy calls for a demonstration of LAW treatment and immobilization by two private vendors at a rate dependent on the type of waste being processed. Envelope A wastes are defined as double-shell slurry feed (DSSF), double-shell slurry (DSS), and dilute non-complexed waste (DN). Envelope B wastes are NCAW supernatants. Envelope $C$ wastes are primarily complexant concentrate (CC). Minimum and maximum processing quantities for each contractor are listed below: 


\begin{tabular}{||l|c|l||}
\hline \hline Waste Type & $\begin{array}{l}\text { Minimum Amount Processes } \\
\text { (Metric Tons Sodium) }\end{array}$ & $\begin{array}{l}\text { Maximum Amount } \\
\text { Processes } \\
\text { (Metric Tons Sodium) }\end{array}$ \\
\hline \hline Envelope A & 2600 & 4900 \\
\hline Envelope B & 100 & 1000 \\
\hline Envelope C & 100 & 2400 \\
\hline Total $A+B+C$ & -- & 5100 \\
\hline
\end{tabular}

Al1 projection cases assumed that each contractor would process the maximum quantity of waste.

- Schedule for LAW Pretreatment. The schedule used for pretreatment of LAW is shown below in Table 6 . Tank dilutions, contractor number, and multiple batches are not shown. This schedule was developed from input supplied by Washenfelder (1996b) except for known tank usage changes (the second feed tank is now Tank 105-AP and not Tank 106-AP as shown in Revision 21 of this document, etc.). Solids are left in the tanks when wastes are retrieved for LAW pretreatment.

Table 6. Projected Pretreatment Schedule for Phase I

\begin{tabular}{||l|c|c|c|c|c|c||}
\hline Tank & Waste Type & Envelope & $\begin{array}{c}\text { Vol Kgal) } \\
\text { w/ solids }\end{array}$ & $\begin{array}{c}\text { MT Na } \\
\text { approx. }\end{array}$ & $\begin{array}{c}\text { Existing } \\
\text { or Future } \\
\text { Waste }\end{array}$ & $\begin{array}{c}\text { Processing } \\
\text { Start }\end{array}$ \\
\hline \hline $105-$ AN & DSSF & A & 1110 & 1186 & Existing & $6 / 1 / 2002$ \\
\hline $105-A P$ & DSSF & A & 1140 & 1238 & Future & $4 / 20 / 2003$ \\
\hline $104-A N$ & DSSF & A & 1061 & 834 & Existing & $3 / 21 / 2004$ \\
\hline $101-A W$ & DSSF & A & 1127 & 906 & Existing & $11 / 12 / 2004$ \\
\hline $103-A N$ & DSS & A & 955 & 1216 & Existing & $7 / 24 / 2005$ \\
\hline $101-A Y$ & NCAW Supern & B & 978 & 250 & Future & $6 / 19 / 2006$ \\
\hline $107-A N$ & CC & C & 1057 & 778 & Existing & $9 / 19 / 2006$ \\
\hline $102-A N$ & CC & C & 1082 & 1004 & Existing & $5 / 29 / 2007$ \\
\hline $106-A N$ & CC & C & 1136 & 1485 & Existing & $3 / 2 / 2008$ \\
\hline $107-A P$ & CC & C & 1104 & 1169 & Existing & $1 / 19 / 2009$ \\
\hline $101-A P$ & DSSF & A & 1140 & 134 & Future & $12 / 6 / 2009$ \\
\hline \hline
\end{tabular}

- Storage of Separated Sr/TRU and Entrained Solids. Entrained solids and transuranic (TRU) elements removed from LAW waste by the private contractors were assumed to be returned to one DST for storage. Tank space was tight enough in FY 2002-3, that the Sr/TRU and entrained solids stream being returned from Phase I treatment is temporarily sent to Tank 102-AZ. By mid 2003, the solids have been removed from Tank 101-AZ and this stream is sent to Tank 101$A Z$ from this time until the end of the projection. 


\subsection{Phase II Privatization Processing}

The scale of processing during Phase I of privatization has been established to demonstrate the technical and commercial capability. Phase II of privatization would include the remaining tank waste retrieval, supernatant pretreatment, sludge/solid pretreatment, LAW immobilization, HLW immobilization, disposition of encapsulated $\mathrm{Cs} / \mathrm{Sr}$, and interim storage of immobilized waste (Washenfelder, 1996b). The proposed target schedule for Phase II processing is summarized below:

- Contract Award 2004

- Design, permitting, licensing, construction, and startup -Low-Activity Wastes

-High-Level Wastes 2005-2011

2005-2013

o Operations

-Low-Activity Wastes 2011-2021

$\begin{array}{ll}\text {-High-Level Wastes } & 2013-2028\end{array}$

- Estimated Processing Rates

-Liquid Wastes, Mgal/yr a 7M Na 22.1

-Solid Wastes, Mgal/yr $r .24$

\subsection{Watch List/Safety}

- A11 three projection cases assumed that agitation using a mixer pump would continue to be used for mitigation of the flammable gas buildup in Tanks 101-SY and 103-SY. It was assumed that these tanks would not require dilution until just prior to retrieval for pretreatment which was scheduled to start in Phase II. To aTlow use of Tanks 101-SY and 103-SY for SST solids retrieval, it was assumed that these two tanks needed to be cleaned out early in Phase II. Tanks 101-SY and 103-SY were diluted $1: 1$ and transferred to East Area during FY 20102011 to meet the pretreatment schedule.

\subsection{Spare/Contingency Space}

- A total of 2.28 million gallons (one aging and one non-aging tank) of spare space was reserved in case of a leak in an aging waste tank (D0E Order 5820.2A) for all three projection cases. From 1999 on, $0.72 \mathrm{Mgal}$ of the operational space in Tanks 102-AW and 106-AW was designated as spare space (Awadalla, 1995) in all three projection cases.

0 At the request of WHC and DOE management, one tank of contingency space has usually been set aside in the long range projection (1999 on) to account for possible inaccuracies in the WVP software when projecting waste generations and/or waste volume reduction factors. To minimize tank space needs, no contingency space is set aside in any of the three projection cases (Awadalla, 1995).

\subsection{Waste Segreqation}

Waste segregation and compatibility are requirements of DOE Order 5820.2A (D0E, 1990) and WAC 173-303-395 (Dangerous Waste Regulations). The overriding purpose of waste 
segregation and compatibility are to ensure the safety of waste storage and tank farms operations; to minimize future pretreatment costs; and to comply with DOE Order 5820.2A and WAC 173-303-393. Wastes that are typically segregated include:

- Phosphate Wastes--dilute phosphate (DP) or concentrated phosphate (CP).

- Wastes Containing High Organic Concentrations--dilute complexed (DC) or complexant concentrate (CC).

- TRU containing wastes--Neutralized Cladding Removal Wastes (NCRW solids) or PFP solids (PT).

- Watch list tank wastes to prevent inadvertent commingling with other wastes.

- Pretreated waste streams.

- Washed NCAW solids, etc.

- Concentrated interim waste types--e.g., double-shell siurry feed (DSSF) or double-shell slurry (DSS) need to be separated from dilute wastes to prevent the need to reconcentrate.

- Wastes exhibiting exothermic reactions.

A11 three projections assume that current waste segregation practices are observed with the exception of SWL pumping in 200 West Area as discussed in Section 3.8. Waste segregation practices are summarized in Table 7 (Fowler, 1995).

\section{Table 7. Waste Compatibility Matrix}

\begin{tabular}{|c|c|c|c|c|c|c|c|c|c|}
\hline & \multicolumn{8}{|c|}{ Receiver Waste Type } \\
\hline & & DN & DSSF & DC & CC & $\begin{array}{l}\text { (PD) } \\
\text { NCRW }\end{array}$ & PT & NCAW & CP \\
\hline S & DN & $x$ & $x$ & $X$ & $x$ & $x$ & $X$ & $x$ & $x$ \\
\hline$u_{r}^{u}$ & DSSF & $X$ & $X$ & & & & & & \\
\hline $\begin{array}{l}\text { c } \\
\text { e }\end{array}$ & DC & & & $x$ & $X^{*}$ & & & & \\
\hline $\mathbf{W}$ & $\mathrm{CC}$ & & & $X^{*}$ & $x$ & & & & \\
\hline$s$ & $\begin{array}{c}\text { (PD) } \\
\text { NCRW SOLIDS }\end{array}$ & $x$ & & & & $x$ & $x$ & & \\
\hline e & $\begin{array}{l}\text { (PT) } \\
\text { PFP SOLIDS }\end{array}$ & $X$ & & & & $X$ & $X$ & & \\
\hline $\begin{array}{l}y \\
p\end{array}$ & NCAW & & & & & & & $x$ & \\
\hline e & CP & & & & & & & & $x$ \\
\hline
\end{tabular}

(*) Adding CC to DC is permitted but would not ordinarily be done. The volume of combined waste which would need to be evaporated would be increased, resulting in increased evaporation costs. 


\section{$\underline{3.23 \text { Loss of DST Space }}$}

Corrosion studies completed to date (Anantatmula and $0 \mathrm{~h} 1,1996$ ) show a $40-60 \%$ chance of a pit corrosion failure occurring in a DST by FY 2028. Some of the corrosion potential could be mitigated by maintaining a corrosion control program for the DSTs. In the Baseline Case, it was assumed that none of the DSTs would be removed from service by the end of FY 2015.

3.24 New DST Construction

A11 three projection cases assumed that no new DSTs would be constructed by 2015 .

\subsection{DST Tank Solids Levels}

Solids levels in the DSTs are shown in Table 8 (Hanlon, 1996; Estey and Guthrie, 1996; and Koreski, 1995). Solids levels have been estimated for the tanks marked with an asterisk $\left(^{\star}\right)$ based on the previous solids level measurement and the percent solids in facility generations that have been added to the tank since the last solids level measurement. Tanks with no solids level listed have either not been measured or have a minimal solids volume. The total DST solids used for this projection was approximately $5.045 \mathrm{Mgal}$.

Table 8. DST Solids Levels (Kgal)

\begin{tabular}{|c|c|c|c|c|c|c|c|}
\hline$\overline{\text { TANK }}$ & SOLIDS & TANK & SOLIDS & TANK & SOLIDS & TANK & SOLIDS \\
\hline$\overline{101-A Y}$ & 83 & 101-AN & 33 & 101-AP & & $101-\mathrm{AW}$ & 344 \\
\hline $102-A Y$ & 32 & $102-\mathrm{AN}$ & 89 & $102-\mathrm{AP}$ & & $102-A W$ & 36 \\
\hline $101-\mathrm{AZ}$ & 35 & $103-\mathrm{AN}$ & 413 & $103-A P$ & & $103-\mathrm{AW}^{*}$ & 487 \\
\hline $102-A Z$ & 95 & $104-\mathrm{AN}$ & 495 & 104-AP & & 104-AW* & 390 \\
\hline $101-S Y$ & 605 & $105-A N$ & 560 & 105-AP & 154 & $105-A W$ & 300 \\
\hline $102-S Y^{*}$ & 133 & $106-\mathrm{AN}$ & 17 & $106-\mathrm{AP}$ & & $106-A W^{*}$ & 225 \\
\hline $103-5 Y$ & 385 & $107-\mathrm{AN}$ & 134 & $107-A P$ & & & \\
\hline & & & & 108-AP & & & \\
\hline
\end{tabular}

\subsection{IMUST Wastes}

Approximately $500 \mathrm{kilogallons}$ of wastes are projected to be received from Independent Miscellaneous Underground Storage Tanks (IMUSTs) between FY 2011 and 2015 (Wacek, 1996). This is a new waste type added to these projections that will be updated in the future.

\subsection{Assumption Summary}

Assumptions used for all cases are presented in Table 9. 
Meets TPA Milestones

Facility Generations

Total Limit, Kgal/mo

\section{PUREX}

Monthly Rate, Kgal/mo

TCO Scheduled

TCO Volume, Kgal

Flush for TCO

WVRF for TCO (to DSSF)

B Plant/WESF

Monthiy Rate, Kgal/mo

Monthly Rate, Kgal/mo

Monthly Rate, Kgal/mo

Flush for misc. waste

WVRF, misc. waste(to DSSF)

TCO Scheduled

TCO Volume, Kgal DN

Flush for TCO

WVRF for TCO (to DSSF)

S Plant

Monthly Rate, Kgal/mo

Monthly Rate, Kgal/mo

Flush for misc. Waste

WVRF, misc. waste(to DSSF)

\section{T Plant}

Monthly Rate, Kgal/mo

Flush for misc. waste

WVRF, misc. waste(to DSSF)

300 Area

Monthly Rate, Kgal/mo

Flush for misc. waste

WVRF, misc. waste(to DSSF)

400 Area

Monthly Rate, Kgal/mo

Flush for misc. Waste

WVRF, misc. waste(to DSSF)

IMUST

Tot. Volume, Kgal (2011-15)

500

8 (1996)

$10(1997-2028)$

$22 \%$

99

2.5 to 3.6

$22 \%$

99

4.5

$44 \%$

94

0.5

$44 \%$

94

$9(1996)$

5 (1997-1998)

$0.5(1999-2028)$

$0 \%$

$6-1998$

$10 \%$

99

$27.9-36.6$

$27.9-36.6$

Lower Planning

Case

No

Yes

Upper Planning

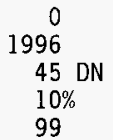

99

1996
45 DN
$10 \%$
99

9 (1996)

$5(1997-1998)$

$0.5(1999-2028)$

$0 \%$

$0 \%$

99

1996-1998

125

$10 \%$

99

99

1996-1998

125

$10 \%$

99

$8(1996)$
$10(1997-2028)$
$22 \%$
99

8 (1996)

10 (1997-2028)

$22 \%$

99

2.5 to 3.6

$22 \%$

99

2.5 to 3.6

$22 \%$

99

4.5

$44 \%$

94

0.5

$44 \%$

94

$44 \%$

94

500

500

Tank Farms

Monthly Rate, Kgal/mo

10

99
10

99
10

99 
WHC-SD-WM-ER-029 Rev. 22

\section{Table 9. Assumption Matrix \\ For the 1996 Operational Waste Volume Projection (continued)}

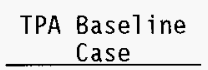

100 Area

$100-\mathrm{N}$

TCO Scheduled

TCO Waste Received

TCO Volume, Kgal

100-K Basin Cleanout

TCO Scheduled

TCO Volume, Kgal

105-F \& 105-H Basin

TCO waste in 2000 , $\mathrm{Kga} 1$

1996-1997

1997

13.5

$1997-2000$

350

40

200

$44 \%$

99
Lower Planning

Case

1996-1997

1997

13.5

1997-2000

350

40

200

$44 \%$

99

$$
\begin{array}{r}
0 \\
99
\end{array}
$$

66

\subsection{7}

0.276

1.250

1,200

Tank 102-SY

1999

2001

1.75

$50 \% / 21 \%$

$26 \%$

47

10
Upper Planning

Case

1996-1997

1997

13.5

1997-2000

350

40

200

$44 \%$

99

0

99

66

5.57

0.276

2. 148

2.323

Tank 102-SY

1998

1999

1.75

$50 \% / 21 \%$

$26 \%$

47

10

\section{Single-Shell Tank (SST) Solids}

$\begin{array}{lr}\text { Tank 106-C Retrieval } & 1997 \\ \text { Start Remaining SST Retv1 } & 2004 \\ \text { Tank Farm Closure start } & 2018 \\ \text { Approximate Dilution Ratio } & 3: 1 \\ \text { Retrieved Vol 2004-2005(Mgal) } & 2.8 \\ \text { Retrieved Vol 2006-2007(Mgal) } & 4.1 \\ \text { Meets TPA Milestones } & \text { Yes } \\ \text { No. SSTs Retrieved } & 149 \\ \text { Sludge Retrieved (Mgal) } & 12.2 \\ \text { Saltcake Retrieved (Mgal) } & 23.4\end{array}$

\section{7}

2004

2018

3:1

2.8

1. 1

Yes

149

12.2

23.4
1997

2004

2018

$3: 1$

2.8

4.1

Yes

149

12.2 
WHC-SD-WM-ER-029 Rev. 22

PFP Stabilization

Dates

Volume, Kgal

Flush

WVRF

Table 9. Assumption Matrix

For the 1996 Operational Waste Volume Projection (continued)

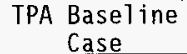

Case

1996- 2006

30

$22 \%$

81
Lower Planning

Case

$1996-2006$

30

$22 \%$

81
Upper Planning

Case

1996-2006

30

$22 \%$

81

Evaporator

241-A Shutdown

New Evaporator (Privatize)

$\sim 2005$

2005

None

Evaporation Product

dDSSF

Evaporation Limit $(\mathrm{g} / \mathrm{ml})$

LERF capacity (Mgal)

Gal. condensate/gal. WVR

Yearly evaporation of DN

(i.e., maintain currency)

Effluent Treatment Facility

$\begin{array}{lc}\text { Start date (mo/yr) } & 11 / 1995 \\ \text { Rate (Mgal/year) } & 50\end{array}$

Watch List/Safety

101-SY Dilution \& date 103-SY Dilution \& date

Require cross-site transfer
1.41

13

Yes

2005

2005

None

dDSSF

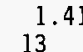

1.26

Yes

2010
Hone
2003
dDSSF

1.41

13

1.26

No

$11 / 1995$

50

$11 / 1995$

50

None

None

No

None

None

No

\subsection{8}

Spare Space, Mgal

2.28

2.28

Yes

None

$N / A$

Yes

None

N/A

5045

Yes

No

Yes

5045

Ves

No

Yes

None

$\mathrm{N} / \mathrm{A}$

None

19

1998

None

$\mathrm{N} / \mathrm{A}$

None

None

$\mathrm{N} / \mathrm{A}$

New Cross-Site Transfer Line
Start Construction (TPA)
Operationa? (TPA)
old line operational
$11 / 1995$
$02 / 1998$
Yes

$11 / 1995$
$02 / 1998$
Yes

$11 / 1995$

$02 / 1998$

Yes 
Table 9. Assumption Matrix

For the 1996 Operational Waste Volume Projection (continued)

DST Retrieval

102-SY solids retrieved to 200 East Area

Consolidation of NCRW

solids in 103-AW

\& 105-AW

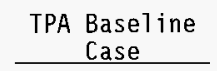

$12 / 1998$

No

Privatization
$08 / 1996$
Yes
$12 / 1999$
$06 / 2002-06 / 2011$
Maximum
4900
1000
2400

100 days

$7 \mathrm{M}, \mathrm{Na}$

Concentration limit of retrieved DSSF, CC

Approximate Volume Pretreated, Mgal

$$
\begin{array}{lll}
Y r & 1 & (06 / 2002-05 / 2003) \\
Y r & 2 & (05 / 2003-06 / 2004)
\end{array}
$$

Vendor Feed Tank

Intermediate Stage Tank

LAW Receipt Tank

Entr. Solid Receipt Tanks

HLW Immobilization of solids

from 101-AZ, 102-AZ,

$106-C$, and 102-AY

HLW Immobilized (MT)

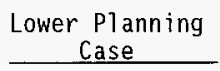

$12 / 1998$

No

Privatization
$08 / 1996$
Yes

$12 / 1999$

06/2002-06/2011

Maximum

4900

1000

2400

100 days

$7 \mathrm{M}, \mathrm{Na}$

2.03

2.22

2(full)

2

0

1

2002-2008

340

2005

2011-2021

2013-2028

22.1

1.24

1.24
2011-2021

2013-2028

HLW Operations

ब7M $\mathrm{Na} 22.1$

Liquid Wastes, Mgal/yr
Solid Wastes, Mgal/yr

In-Tank Washing

Case Identification

Consolid. of NCAW solids

Consolidate NCAW

supernate to

Decant 101-AZ

Decant 102-AZ

Decant 102-AY

\author{
8 Modified \\ No
}

8 Modified

No

101-AY + 1 DST

$10 / 1997$

$10 / 2000$

$10 / 2003$

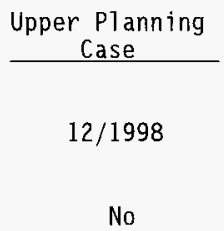

Privatization

08/1996

No.

$12 / 1999$

06/2002-06/2011

Maximum

4900

1000

2400

100 days

$7 \mathrm{M}, \mathrm{Na}$

2.03

2.22

2(ful1)

2

0

1

2002-2008

340

2005

2011-2021

2013-2028

22.1

1.24

8 Modified

No

101-AY + 1 DST

$10 / 1997$

$10 / 2000$

$10 / 2003$ 


\subsection{LOWER AND UPPER PLANNING CASE ASSUMPTIONS}

The Baseline Case is meant to project DST needs based on TPA milestones, TWRS program planning, and the most realistic operational assumptions. The Baseline Case presents a basis for evaluating future DST space needs through the end of FY 2015. This report presents a projected range of tank needs which is used to generate recommendations regarding site activities, waste management activities, facility requirements, and the need to build additional double-shell tanks. This document presents the results of three projections cases--Baseline Case, Lower Planning Case, and the Upper Planning Case. Assumptions presented for the Lower and Upper Planning Case do not always reflect TPA milestones but present a range of operational assumptions meant to answer the impact of various delays or changes on DST need. The Lower and Upper Planning Cases do not present a lower or an upper limit on double-she11 tank needs which could vary significantly depending on the assumption changes. Operating assumptions for the Baseline Case were established in May 1996 (Barton, 1996). The following section will describe assumptions specific to the Lower and Upper Planning Cases. These assumptions are also summarized in Table 9.

\subsection{Lower Planning Case Assumptions}

Assumptions for the Lower Planning Case are the same as those for the Baseline Case except for the following:

- Saltwell Liquid Pumping. The volume of waste pumped per year was reduced during 1997-1998 and the pumping of complexed waste in 200 West Area was delayed until 1999 which allowed completion of the cross-site transfer 7 ine and removal of the solids from Tank 102-SY to be completed. The SWL assumption changes for the Lower Planning Case have been highlighted below for easier comparison to the assumptions for the Baseline Case:

\begin{tabular}{|c|c|c|}
\hline Assumption & $\begin{array}{c}\text { Baseline and Upper } \\
\text { Planning Cases }\end{array}$ & $\begin{array}{c}\text { Lower Planning } \\
\text { Case }\end{array}$ \\
\hline Volume Pumped in 1996 (Mgal) & 0.276 & 0.276 \\
\hline Volume Pumped in 1997 (Mgal) & $2.1 \overline{48}$ & 115 \\
\hline Volume Pumped in 1998 (Mgal) & 2.323 & 1.20 \\
\hline Volume Pumped in 1999 (Mgal) & 0.772 & 1.178 \\
\hline Volume Pumped in 2000 (Mgal) & 0 & 1003 \\
\hline Volume Pumped in 2001 (Mgal) & 0 & 0.57 \\
\hline $\begin{array}{l}\text { Start Complexed SWL Pumping in } \\
200 \text { West Area }\end{array}$ & 1998 & 1999 \\
\hline Pumping Completion, FY & 1999 & 2001 \\
\hline
\end{tabular}


- Single-Shell Tank Solids Retrieval. The volume of single-shell tank solids retrieved was reduced during the period FY 2004 to 2007 to demonstrate the impact of delaying SST solids retrieval on DST space requirements. The volume changes were assumed to be moved to FY 20172018. Again, the SST solids retrieval assumption changes have been highlighted below for easier comparison to the assumptions for the Baseline Case:

\begin{tabular}{|c|c|c|}
\hline As sumption & $\begin{array}{c}\text { Baseline and Upper } \\
\text { Planning Cases }\end{array}$ & $\begin{array}{c}\text { Lower Planning } \\
\text { Case } \\
\end{array}$ \\
\hline $\begin{array}{l}\text { Volume Retrieved in } 2004 \\
\text { (Mgal) }\end{array}$ & 0.8 & 0.8 \\
\hline $\begin{array}{l}\text { Volume Retrieved in } 2005 \\
\text { (Mgal) }\end{array}$ & 2.0 & 2.0 \\
\hline $\begin{array}{l}\text { Volume Retrieved in } 2006 \\
\text { (Mgal) }\end{array}$ & 2.4 & 0.87 \\
\hline $\begin{array}{l}\text { Volume Retrieved in } 2007 \\
\text { (Mgal) }\end{array}$ & 1.7 & 0.78 \\
\hline $\begin{array}{l}\text { Volume Retrieved in } 2008 \\
\text { (Mgal) }\end{array}$ & 1.3 & 1.3 \\
\hline
\end{tabular}

\subsection{Upper Planning Case Assumptions}

Assumptions for the Upper Planning Case are the same as those for the Baseline Case except for the following:

- Loss of Double-shell Tank Space. At the request of the Washington Department of Ecology, one tank was removed from service in 1998 (Hepner, 1996). For these purposes, Tank 107-AN was selected as the tank removed from service. Tank 107-AN is currently caustic deficient and could be more susceptible to corrosion.

- Evaporation Maintenance Outage. The 242-A Evaporator was shutdown in Fy 2003 for a one year period for maintenance.

- Loss of Evaporation Capability. A loss of evaporation capability was assumed from FY 2010 to the end of the projection. 
WHC-SD-WM-ER-029 Rev. 22

\subsection{RESULTS AND CONCLUSIONS}

The results of a waste volume projection can be used to forecast tank space needs versus time, forecast evaporator operation, LAW pretreatment and disposal, HLW pretreatment and disposal, analyze tank space issues for aging and non-aging waste tanks, tank usage, or to determine the need and schedule for retrievals or cross-site transfers. To predict tank space needs, a graphic is produced showing tank count versus time as compared to the available space. A short range waste volume projection predicts tank space needs over approximately a three year period in monthly intervals. A long range waste volume projection predicts tank space needs over a longer range (1994-2015) in yearly intervals.

Except for near term scheduled evaporator operations, both types of projections assume that dilute waste will be evaporated to DSSF in the year they are produced, provided an evaporator is operational and the WVR limit of the evaporator has not been exceeded. In later parts of the Baseline and Lower Planning Case projections when tank space becomes tight due to pretreatment needs and/or the amount of SST solids being retrieved, the evaporator is assumed to operate yearly even if volumes are small to minimize waste storage needs. Long range projection graphics for the Baseline, Lower Planning, and Upper Planning Case are presented in Sections 5.1, 5.2, and 5.3, respectively. Short range graphics, tank usage graphics, evaporator WVR data, and a spreadsheet showing inputs/outputs have been included for the Baseline Case only. Results of the projection cases are included in the following sections.

\subsection{Baseline Case Results and Conclusions}

Assumptions for the Baseline Case represent the current planning basis for TWRS programs. The one exception is the Phase II disposal plant capacity which has been increased to match retrieval rates to assure sufficient tank space was available. Projected tank space needs for the Baseline Case are shown in Figure 3 . The Baseline Case manages projected tank space needs within the available tank space (28 DSTs) by incorporating several space saving assumption changes that were not included in the previous document. These space saving alternatives eliminate the need to build additional DSTS but add additional risks to the TWRS program. These actions and some of the risks are listed below:

- Waste generation rates and TCO volumes have been reduced compared to previous projections.

- It was assumed that agitation using a mixer pump wouid continue to be used for mitigation of the flammable gas buildup in Tank 101-SY. It was assumed that neither Tank 101-SY or 103-SY would require dilution until just prior to retrieval for pretreatment during Phase II processing. Since additional space in 200 West Area will be needed to handle SST solids retrieval, Tanks 101-SY and 103-SY were assumed to be the first two tanks treated in Phase II processing (an exact sequence of tanks for Phase II had not been determined before this projections was completed). This meant the 1:1 dilution for these tanks was completed in 2010-2011 to allow retrieval and mixing prior to the startup of Phase II processing in FY 2011. 
If the mixer pump option was not available to meet the flammable gas buildup and a $1: 1$ dilution was required at a future date the increase in tank space to dilute both Tanks 101-SY and 103-SY would be approximately 1.9 million gallons.

o In Revision 21 of this document, it was assumed that all NCAW solids and the 106-C solids would be combined into one aging waste tank (Tank 102AZ) and that all NCAW supernates would be concentrated into one aging waste tank (Tank 101-AZ). Since that document was published, studies have been completed which looked at numerous sludge washing/combination options (Powel1, 1996a). The alternatives for consolidating high heat sludges have been reviewed by a decision board comprised of WHC management, a DOE/RL representative, and a WDOE representative. It was concluded that consolidating all the sludges into a single tank would require modifications to the tank farm safety basis. The preliminary decision reached was not to consolidate all the high heat sludges into a single tank. The selected alternative (Alternative 8 Modified) would wash the sludges in the tanks they reside in without additional consolidation of solids. The NCAW supernates could not be combined into a single aging tank (Tank 101-AY) due to the $5 \mathrm{M} \mathrm{Na}$ limit but would be concentrated and sent to Tank 101-AY and an additional non-aging tank (Powel1, 1996b). This action has increased DST needs from FY 2001 as compared to Revision 21 DST space needs.

0 In Revision 21 of this document, it was assumed that a17 NCRW and PFP solids could be consolidated into one DST (Awadalla, 1995). In this document (Rev. 22) it was assumed that the solids in Tanks 103-AW and 105-AW would not be combined. However, the PFP solids from Tank 102-SY and the solids from the 100 Area TCO activities were combined into Tank 105-AW. To further minimize the impact of this non consolidation of solids compared to Revision 21 , this projection assumed that slurry feed (DSSF) could be stored on top of the TRU solids in Tanks 104-AW and 105AW. The acceptability of this assumption is still being reviewed.

- Operational space in Tanks 102-AW and 106-AW was used to provide 0.72 Mgal of the required $2.28 \mathrm{Mgal}$ of spare space from 1999 on (Awadalla, 1995). This assumption change reduces operational space which may create operational/space problems during the period when SST solids are being retrieved.

- Tank space in the Baseline Projection is tight enough that additional waste transfers and multiple uses of a tank were required to stay within the available space. For example, the excess DSSF produced in FY 199899 had originally caused a tank space shortage of one tank. To alleviate this problem required tank use changes:

Tank 101-AN was being used for dilute waste receipts but had to be used to store the excess DSSF. This meant that Tank 102-AY had to be used as a dilute receiver from FY 1998-2000. Tank 102-AY could not be used as a dilute receiver beyond FY 2003 because it was scheduled for in-tank washing beginning in FY 2003. After the DSSF was removed from Tank 101-AN in late 2000, it was again used to receive dilute wastes. 
Tank space was tight enough in FY 2002-3, that the Sr/TRU and entrained solids stream being returned from Phase I treatment is temporarily sent to Tank 102-AZ. By mid 2003, the solids have been removed from Tank $101-A Z$ and this stream is sent to Tank 101$A Z$ from this time until the end of the projection.

- Tank 102-SY was used to pump complexed SWL in West area starting in mid FY 1998 in order to meet intermediate TPA milestones for SWL pumping. Retrieval of the TRU solids in this tank is not scheduled unti1 12/1998. Segregation issues involving contacting complexed SWL with the TRU hee? in Tank 102-SY may make this assumption impossible which could delay SWL pumping TPA milestones (see Section 3.8 for more on SWL pumping).

- Single-shell tank solids are scheduled for retrieval starting in FY 2004. Retrieval has assumed that these wastes will have to be diluted to approximately $5 \mathrm{M} \mathrm{Na}$ or 10 wt\% solids for retrieval purposes. To minimize storage space, it was assumed that the retrieved wastes could be reconcentrated to $7 \mathrm{M} \mathrm{Na}$ for storage purposes (Washenfelder, 1996b). If the retrieved single-shell tank solids cannot be reconcentrated, the pretreatment rate would need to be increased sharply to avoid a tank space shortage.

- At the request of DOE and WHC management, revisions of this document prior to Revision 21 had included one tank of contingency space in the long range portion (FY 1999 on) to account for any inaccuracies in waste generation rates or waste volume reduction factors. This contingency space has been removed (Awadalla, 1995).

- In the Baseline Projection it was assumed that evaporator capacity was available on an annual basis from FY 1996-2015. A reduction in evaporation capacity during years when space is tight or when waste receipts are high could result in a tank space shortage.

- This projection assumed that dilute non-complexed waste could be evaporated to a specific gravity (SpG) of 1.41. Limiting the evaporation of waste to a SpG of 1.41 has been proposed as an acceptable threshold for preventing the accumulation of flammable gas in DSTs (Fowler, 1995b). The special projection L9503A which was completed in April 1995 (Awadalla, 1995) reduced waste to a SpG of 1.35 . The higher specific gravity limit used in this projection allows waste to be evaporated further, saving approximately $2 / 3$ of a tank by the end of the projection.

- Some double-shell tanks are nearing their design life. The Baseline Projection does not provide for the loss of any DST space through 2015. The volume of this impact would be approximately one million gallons if one DST is lost (see the Upper Planning Case).

The space saving actions 1 isted above eliminate the need for construction of new DST space that was recommended based on previous projection (Rev. 20) but introduce additional uncertainties and risks into the overall TWRS program. If many of these items are not possible or if waste generations exceed those used in this projection, it may be necessary to either delay site cleanup activities, delay TPA milestones (e.g., SWL pumping and/or SST solids 
retrieval), increase the waste pretreatment rate, or build additional tank space in order to avoid exceeding the available DST space. Additional studies are currently in progress to address and solve the issues that have been identified.

A spreadsheet summarizing the waste generations, evaporator WVR, and pretreatment requirements has been added to this document and is included as Table 10. This spreadsheet is included to present a global view of how the various inputs and outputs affect tank space. This spreadsheet is useful to review waste inventories and waste receipts but cannot accurately predict the dynamics of tank usage or the full impact of partially filled tanks on tank space needs.

Figure 4 shows the waste additions and available space in a bar graph format to allow the user to more easily visualize the tank space usage. Numbered comments have been added to the bar graph explaining the inventory changes. These comments follow the figure.

In conclusion, the Baseline projection case extends through 2015 and does not require building new tanks based on current assumptions. Should the projection require building new tanks, approximately six to eight years lead time would be required to provide additional storage tanks. Consequently, a decision to add storage capacity can be delayed until 1998 when the tank space needs will be re-evaluated. Annual evaluation of tank space needs and the decisions on additional storage capacity are required by the M-46 series TriParty Agreement Milestones. 


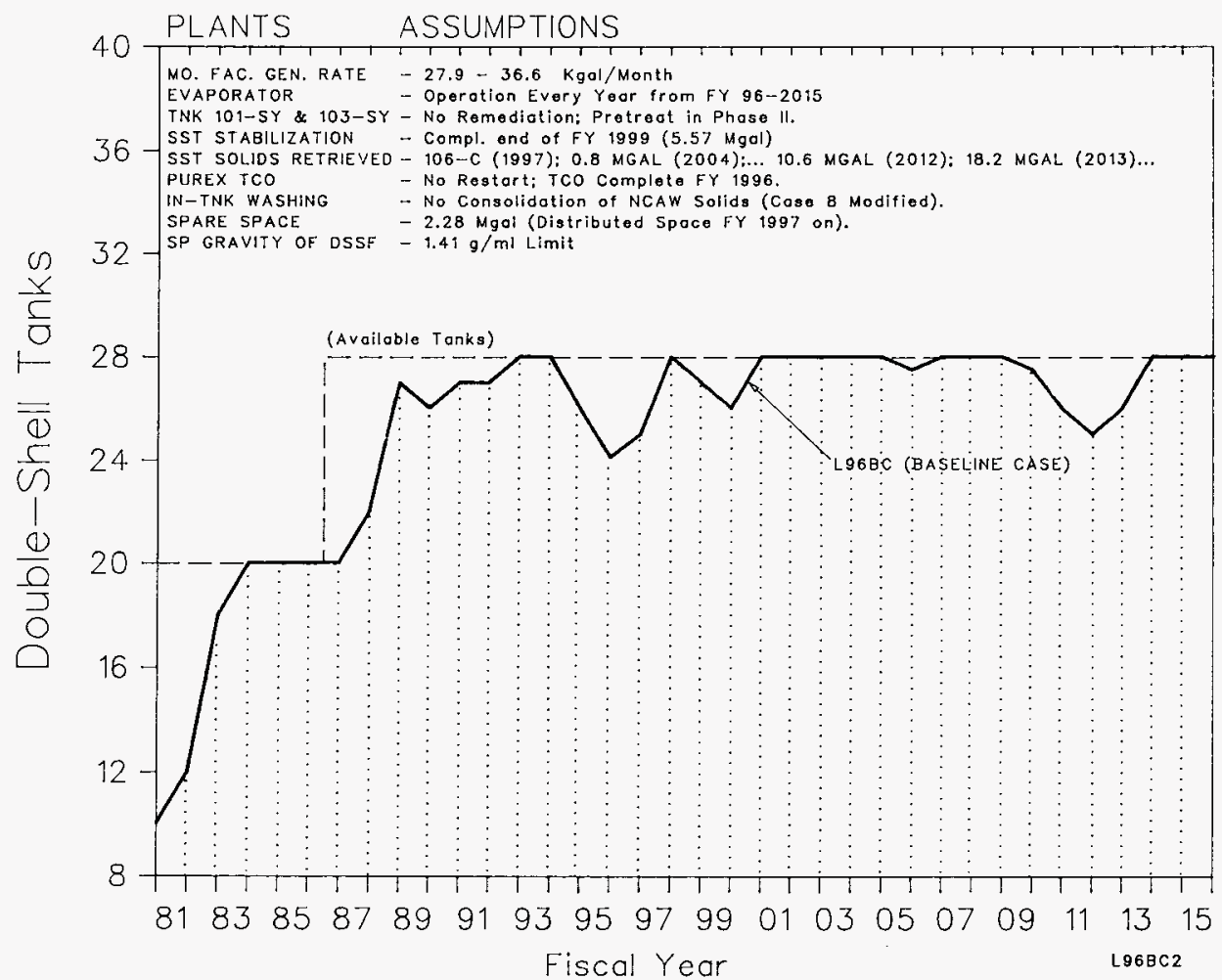

Figure 3. Double-Shell Tank Requirements for the Baseline Case 


\section{Table 10. Spreadsheet of Waste Additions and Reductions for Baseline Case}

FISCAL, YEAR

STARTING INVENTORY

SPACE UTILIZATION

Spare Space.

Contingency Space

Segregated Space

Priority Operational Space

NEW WASTE ADDITIONS

B Plant WSCF

SPlant

TPlant

$300 / 400$ Areas

TCO

Flushes

SWL Pumping

Tank Farms

SST Retrieval

PFP

$\omega$ Inventory

Retrieval Water

Everything Else

Pretreatrent Dilution

In-Tank Washing

TOTAL WASTE BEFORE EVAP

EVAPORATOR WVR

CUM EVAPORATOR WVR

Outfow to Pretreatment Facility

Outflow to the Vitrification Plant

EVAP \& OUTFLOWS TOTAL

NET INVENTORY CHANGE

END OF YEAR INVENTORY

TOTAL CAPACITY

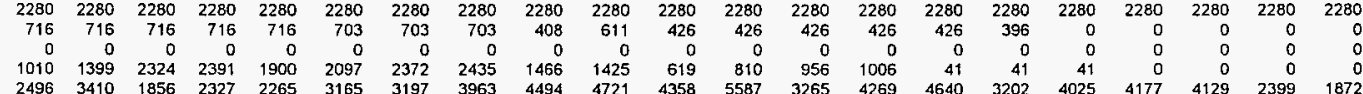

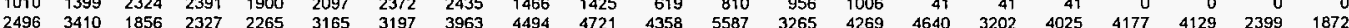

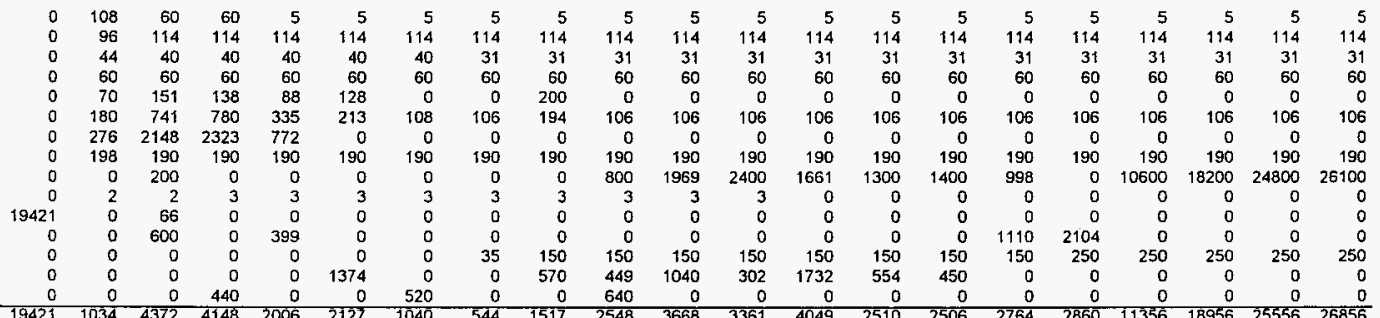

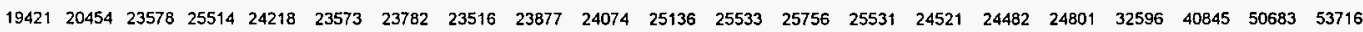

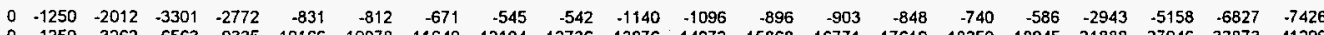

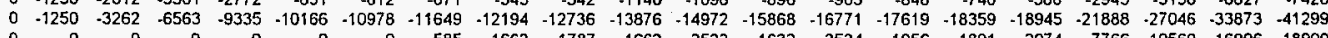
$\begin{array}{lllllllllllllllllllll}0 & 0 & 0 & 0 & 0 & 0 & 0 & -585 & -1662 & -1787 & -1662 & -2522 & -1632 & -2524 & -1956 & -1801 & -2974 & -7766 & -10560 & -16996 & -18900\end{array}$

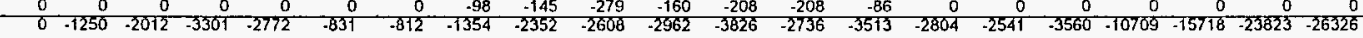

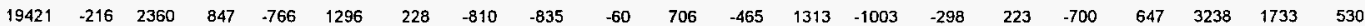

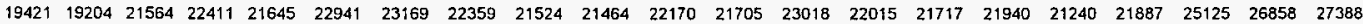

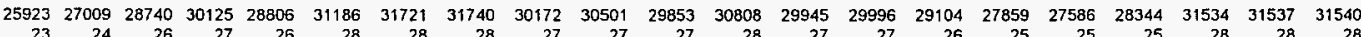




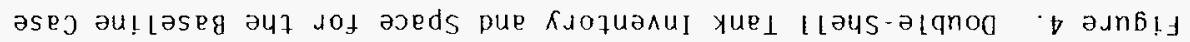

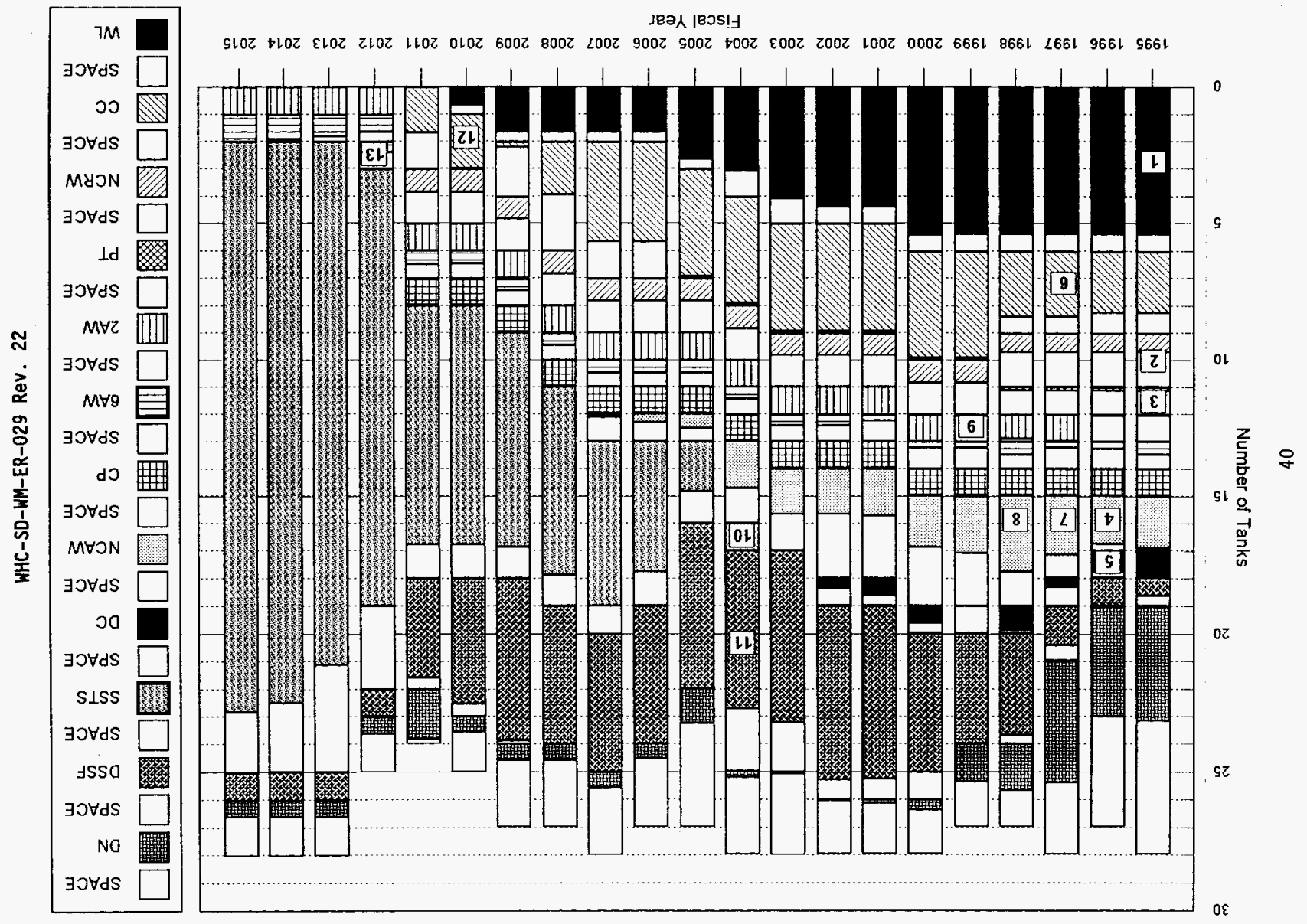


Comments for Figure 4--Double-Shell Tank Inventory and Space for the Baseline Case

This bar chart graphic is meant to show the increase and decrease in the various waste categories or waste types for the Baseline Projection L96BC. Tank space needs for "in-tank washing" have been included. Spare and pretreatment receipt tanks are not shown. Beginning in 1999, a portion of the evaporator operational space maintained in Tanks 102-AW and 106-AW

(abbreviated $2 \mathrm{AW}$ and $6 \mathrm{AW}$ on Figure 4) will also be considered as spare space to decrease tank space needs. Levels of Dilute Non-complexed waste (DN) in the dilute receiver and evaporator tanks will vary with time. The bar for each year depicts the tank space needs for the end of that fiscal year and may not show tank space changes occurring during the fiscal year.

Numbered Comments for "Tank Inventory and Space" Graphic

1. "Watch List" (WL) tank inventories are constant from 1995-2000. In FY 2000 , the contents of Tank 105-AN are diluted and transferred to the intermediate staging tanks to supply feed for Phase I pretreatment.

2. Space above Neutralized Cladding Removal Waste (NCRW) solids is routinely used to store Dilute Non-complexed (DN) waste. For clarity, the graph shows this DN inventory in with the other DN inventory toward the top of the graph. (i.e, to ascertain "free" space, add the space shown in the NCRW group to that shown in the ON group).

3. Space above PFP Tru (PT) solids is used to store DN waste, (see note 2). It is assumed that complexed salt well liquid pumping in 200 West Area would be added to Tank 102-SY before the PT (PFP TRU) solids were retrieved (see note 9 ).

4. The slight decrease in the NCAW category in 1996 is caused by in-tank concentration of the NCAW supernates.

5. In 1996 there is an increase in space above the Dilute Complexed (DC) waste inventory. This results from pumping the DC waste from Tank 101-AY (980 Kgal) to Tank 108-AP (1140 Kgal tank), thus creating more net headspace. Reduction in the DC waste inventory in 1997 is caused by an evaporation. Evaporation is necessary to prevent overfill of Tank 108AP. Projection L96BC included approximately $1.75 \mathrm{Mgal}$ of additional complexed SWL as compared to the previous 2.1 Mgal projection for the $6 / 95$ OWVP.

6. The CC (or DSSF) group shows increases in inventory over time (e.g., 1997) due to the evaporation of complexed wastes. When a CC tank becomes ful1, a new tank must be added, which obviousiy has empty space in it. This is shown graphically year-to-year with step increases in the number of CC tanks and variations in the available space shown in the group. Increase in CC volumes occur due to Salt We11 Liquid (SWL) pumping.

7. The increase in NCAW tank needs in 1997 results from the retrieval of Tank 106-C solids to Tank 102-AY. Tank 106-C solids are high heat solids that have been added to the NCAW waste category (must be stored in aging waste tanks, e.g. 102-AY). 
8. The increase in NCAW inventory and tank needs starting in 1997 were partially caused by in-tank washing of the NCAW solids. The final result of the operations were completed by the end of FY 2004 but the NCAW solids vitrification is not completed until FY 2008 and included (See Table 5 for additional detail):

- No consolidation of NCAW solids.

- NCAW supernates were evaporated and combined into Tank 101-AY.

9. The PT (PFP TRU) solids from Tank 102-SY were cross-sited to Tank 103-AW beginning 12/98. Therefore, the PT waste category and space are eliminated by the end of FY 99.

10. Retrieval of Single-Shell Tank Solids (SSTS) was started in FY 2004. Initial SST solids were stored in Tanks 104-AN and 102-SY.

11. Decrease in DSSF inventory in FY 2003 results from Phase I pretreatment.

12. Increase in CC inventory in 2010 is caused by dilution and staging of watch list waste from Tank 101-SY for pretreatment in Phase II. The watch list tank count has decreased by one and the CC inventory has increased due to dilution and staging. In 2011 the watch list category has been eliminated when Tank 103-SY has been diluted and staged for pretreatment.

13. CP waste is pretreated in FY 2012 and this category is eliminated. 


\section{Interpretation of Short Range Projection Results}

This section provides an interpretation of detailed short range projection results. The OWVP presents certain information in the form of graphics. A number of these graphics show 12 months of historical operations and 24-36 months of projected operations. Most of the vertical axis represents thousands of gallons of waste generated. An example of this type of graphic is the facility waste generation graphic. The volume generated per month for each facility is depicted on a facility waste generation graph. An example of the facility waste generation graph for PUREX waste is shown below (Figure 5).

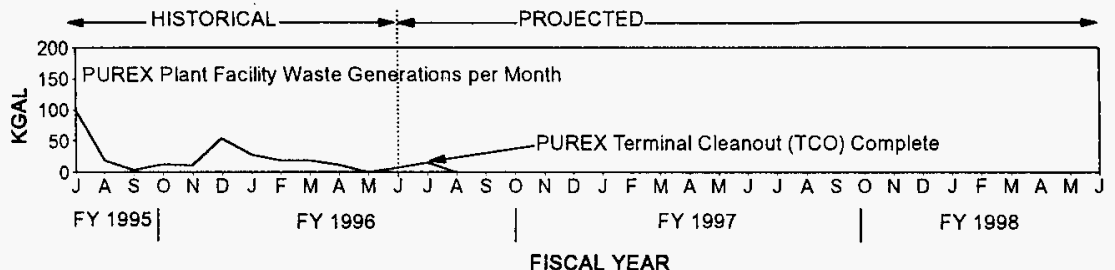

Figure 5. Facility Waste Generation Graphic

In the computer simulation, facility waste streams are routed to a receiver tank. A tank fill graphic shows the filling of the receiver tank and is on the same page as the facility waste generation graph of the waste stream it receives. The tank fill graphic shows the rate a specific tank is filled with waste. Usually when a receiver tank is full, waste is transferred to a holding tank. This waste is either evaporated or stored for future disposal. For every transfer out of a tank, there is a corresponding receipt of the same volume into another tank or facility. For every evaporation out of a tank there is a corresponding receipt of the more concentrated waste in the receiving tank and an increase in the condensate from the 242-A Evaporator being sent to the LERF.

An example of this type of graph (a tank fill graphic) for Tank 105-AW is shown below (Figure 6 ).

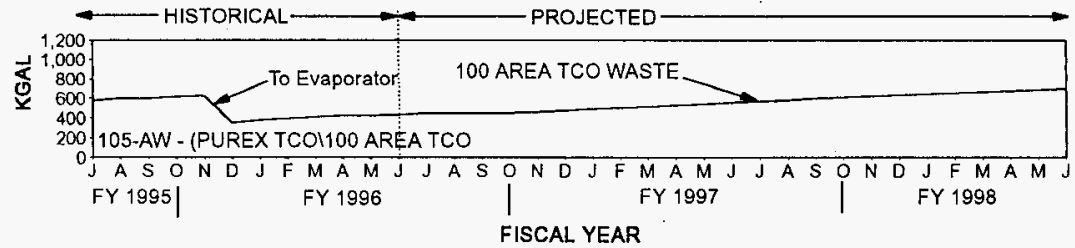

Figure 6. Tank Fill Graphic 
The accuracy of this projection is directly related to the facility supplied assumptions. Some of the major assumptions are listed below:

- Process operating schedules define the planned dates of plant operations or deactivation activities. These assumptions are consistent with the TWRS program planning. Volumes and schedules for the various Hanford facilities for the three projection cases are presented in Sections 3 and 4 .

- Plant waste generation assumptions define the volume and type of waste that will be generated by the plants. These assumptions result from an analysis of recent waste generation history and future plans specified by the plants. Most waste streams volumes are projected based on historical data and/or facility supplied operating schedules. Section 5.4 includes a comparison of actual waste receipts to the new facility waste generation targets for the period October 1995 to June 30, 1996.

Tank roles and waste routings define the use of tanks in the system. For example, a tank will be designated to act as receiver of the PUREX facility miscellaneous waste (Tank 105-AW), while other tanks will store concentrated waste.

The graphics depicted on the next few pages summarize the short range projection results of the Baseline Case. Figure 7 shows the role of each tank for a period of four years. It should be noted that if a tank has several transfers in or out of the tank in one month, no fluctuation in the tank level may appear. This is because the graphic program plots tank levels as of the last day of the month and any changes that occur during the month are not shown. The simplified routing schematic shown in Figure 8 depicts the assumptions that are made about the routing of waste from the plants to the tanks and from tanks to the facilities. 
WHC-SD-WM-ER-029 ReV. 22

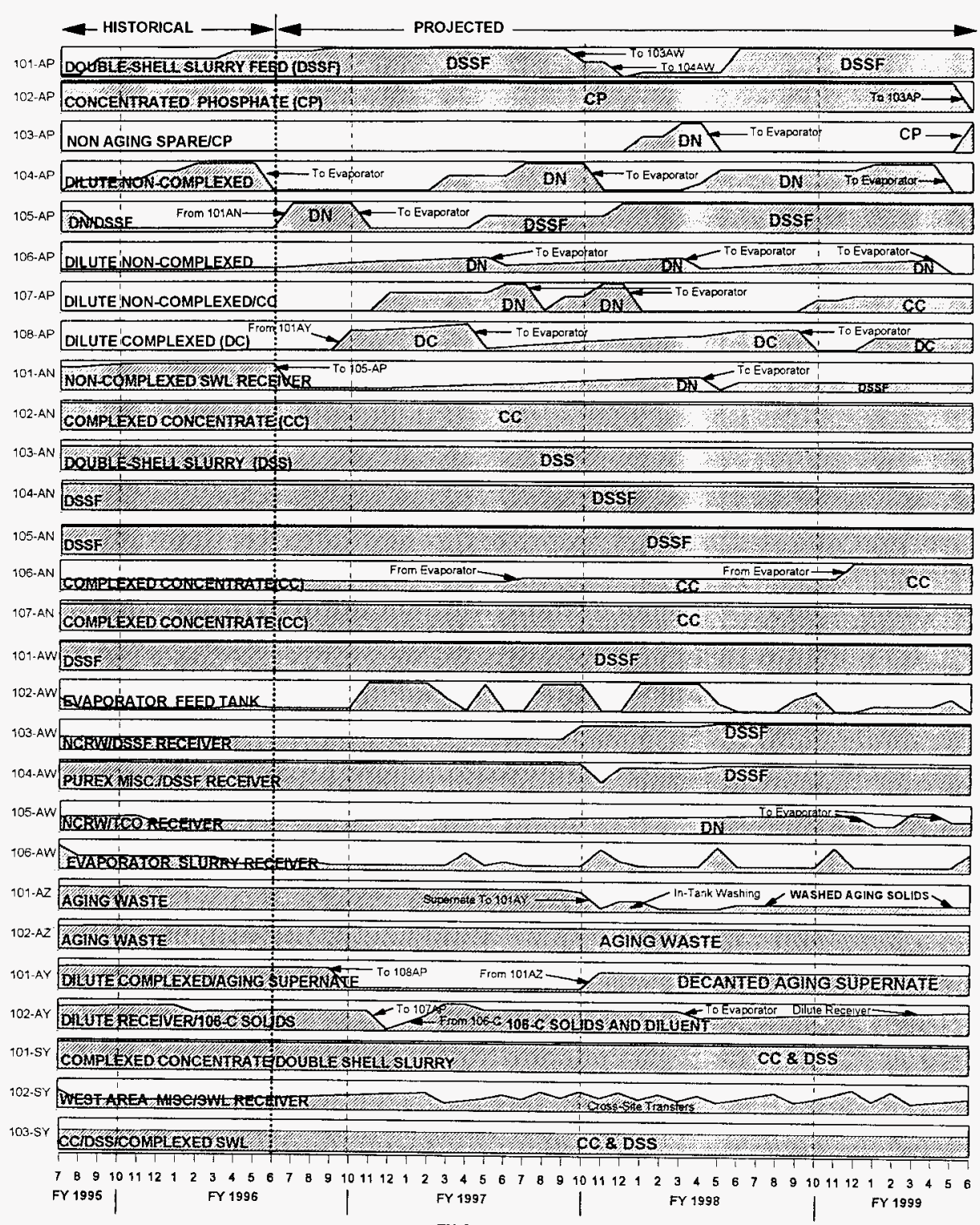

FISCAL YEAR

Figure 7. Tank Levels During the Short Range Projection 


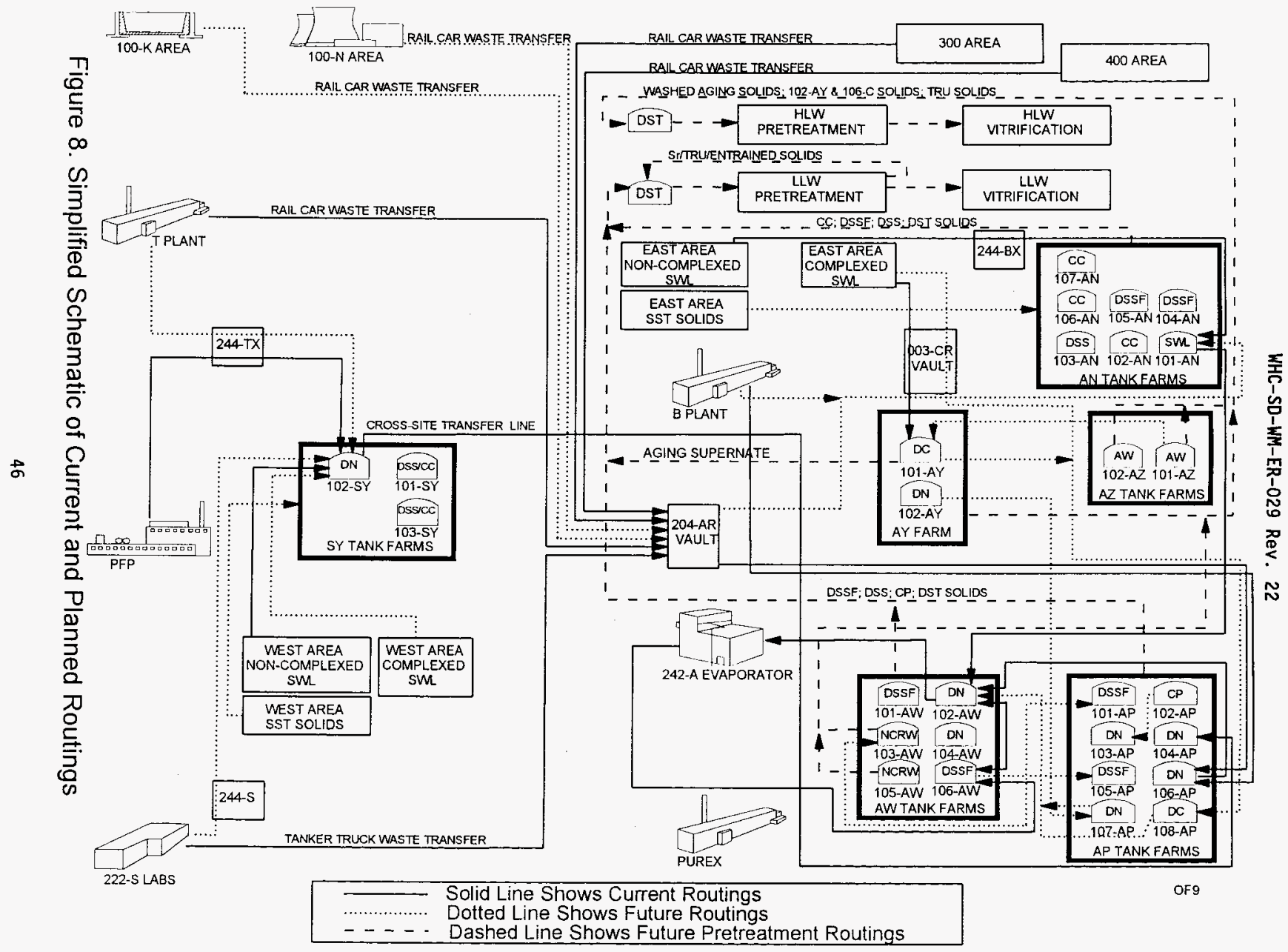


The results of this projection are forecasts of evaporator operations, LAW pretreatment and disposa1, HLW pretreatment and disposal, and an analysis of tank space issues for aging and non-aging waste tanks.

\section{Evaporator WVR and LERF Condensate}

Schedule and operational considerations presented in Section 3 result in the following Evaporator Waste Volume Reduction (WVR) and LERF Condensate production volumes for the Baseline Case. The ratio of process condensate sent to LERF for every gallon of Waste Volume Reduction (WVR) for Evaporator Campaigns 94-1, 94-2, and 95-1 was $1.29,1.24$, and 1.26 , respectively (Guthrie, 1996). The average for the first three campaigns was 1.26 gallon of condensate/gallon of WVR which was the value used in this document to project future condensate production recorded in Table 11 . These volumes also assume that there will be no evaporator outages before 2015. The waste sources, campaign schedule, and concentrated waste receiver tanks used in this projection are summarized Table 12.

Table 11. Evaporator WVR and LERF Additions for the Baseline Case

\begin{tabular}{|c|c|c|}
\hline FISCAL YEAR & $\begin{array}{l}\text { EVAPORATOR } \\
\text { WVR (KGAL) }\end{array}$ & $\begin{array}{l}\text { CONDENSATE TO } \\
\text { LERF (KGAL) }\end{array}$ \\
\hline 1996 & 1250 & 1580 \\
\hline 1997 & 2000 & 2500 \\
\hline 1998 & 3300 & 4160 \\
\hline 1999 & 2770 & 3490 \\
\hline 2000 & 830 & 1050 \\
\hline 2001 & 810 & 1020 \\
\hline 2002 & 480 & 600 \\
\hline 2003 & 550 & 690 \\
\hline 2004 & 540 & 680 \\
\hline 2005 & 1140 & 1440 \\
\hline 2006 & 1100 & 1390 \\
\hline 2007 & 900 & 1130 \\
\hline 2008 & 900 & 1130 \\
\hline 2009 & 850 & 1070 \\
\hline 2010 & 740 & 930 \\
\hline 2011 & 590 & 740 \\
\hline 2012 & 2940 & 3700 \\
\hline 2013 & 5160 & 6500 \\
\hline 2014 & 6930 & 8730 \\
\hline 2015 & 7430 & 9360 \\
\hline
\end{tabular}


Table 12. Evaporator Campaign Schedule for the Baseline Case

\begin{tabular}{|c|c|c|c|c|c|c|}
\hline Campaign & $\begin{array}{l}\text { Start } \\
\text { Date }\end{array}$ & $\begin{array}{l}\text { Staging } \\
\text { Tank(s) }\end{array}$ & Source & $\begin{array}{c}\text { Waste Feed } \\
\text { Type }\end{array}$ & $\begin{array}{l}\text { Feed } \\
\text { Vol ume } \\
\text { (Kgal) }\end{array}$ & $\begin{array}{l}\text { Receiver } \\
\text { Tank }\end{array}$ \\
\hline $97-1$ & $2 / 97$ & 105-AP & $\begin{array}{c}102-A W(102-A Y) \\
101-A N\end{array}$ & $\begin{array}{c}\text { DN } \\
\text { DN-SWL }\end{array}$ & $\begin{array}{l}400 \\
970\end{array}$ & $\begin{array}{l}101-A P \\
105-A P\end{array}$ \\
\hline $97-2$ & $5 / 97$ & 108-AP & $101-A Y \& 106-A N$ & $D C$ & 900 & $106-\mathrm{AN}$ \\
\hline $98-1$ & $10 / 97$ & $\begin{array}{l}107-A P \\
104-A W \\
104-A P\end{array}$ & $\begin{array}{c}106-\mathrm{AP} \& 102-\mathrm{AY} \\
104-\mathrm{AW} \\
102-\mathrm{SY}\end{array}$ & $\begin{array}{c}\text { DN } \\
\text { DN } \\
\text { DN-SWL }\end{array}$ & $\begin{array}{l}1100+ \\
740+ \\
1000\end{array}$ & $\begin{array}{l}105-A P \\
101-A P\end{array}$ \\
\hline $98-2$ & $4 / 98$ & $\begin{array}{l}\text { 107-AP } \\
\text { I03-AP }\end{array}$ & $\begin{array}{l}102-S Y \\
102-S Y\end{array}$ & $\begin{array}{l}\text { DN-SWL } \\
\text { DN-SWL }\end{array}$ & $\begin{array}{l}1000 \\
1000\end{array}$ & $\begin{array}{l}101-A P \\
104-A W \\
101-A N\end{array}$ \\
\hline $99-1$ & $10 / 98$ & $108-A P$ & E.Saltwells/Gen & DC-SWL & 850 & $\begin{array}{l}106-\mathrm{AN} \\
107-\mathrm{AP}\end{array}$ \\
\hline $99-2$ & $4 / 99$ & $\begin{array}{l}101-A N \\
104-A P \\
106-A P\end{array}$ & $\begin{array}{l}101-A N \\
102-S Y \\
106-A P\end{array}$ & $\begin{array}{l}\text { DN-SWL } \\
\text { DN-SWL } \\
\quad \text { DN }\end{array}$ & $\begin{array}{l}1000+ \\
1000+ \\
1000\end{array}$ & 101-AN \\
\hline $99-3$ & $8 / 99$ & 108-AP & E.Gen, 102-SY & DC-SWL & 1000 & 107-AP \\
\hline
\end{tabular}

Note: Tank 101-AP is characterized and once the contents are found to be suitable, the DSSF contents are stored on top of the solids in Tanks 103-AW and 104-AW in early 1998. This allows Tank 101-AP to be refilled later in 1998. This method should allow topping off Tanks 103-AW and 104-AW with DSSF with less likelihood of producing another watch list tank than direct transfers from Tank 106-AW. 
See Figure 9 for dilute receiver tanks, evaporator WVR, and the 242-A Evaporator operating schedules for the Baseline Case.

Based on the $50 \mathrm{Mgal} /$ year treatment capacity for the ETF, the ETF should have no problem processing the projected evaporator condensates thru 2015. There should be sufficient LERF and DST space for storage of Hanford facilities generated waste and condensates between FY 1996 and the end of 2015, provided:

- the 242-A Evaporator schedule is achieved

- the amount of condensate sent to LERF does not grossly exceed the 1.3 gallon condensate/gallon WVR factor

- facilities stay within their respective generation limits

- no unexpected waste receipts are received in the DSTS 

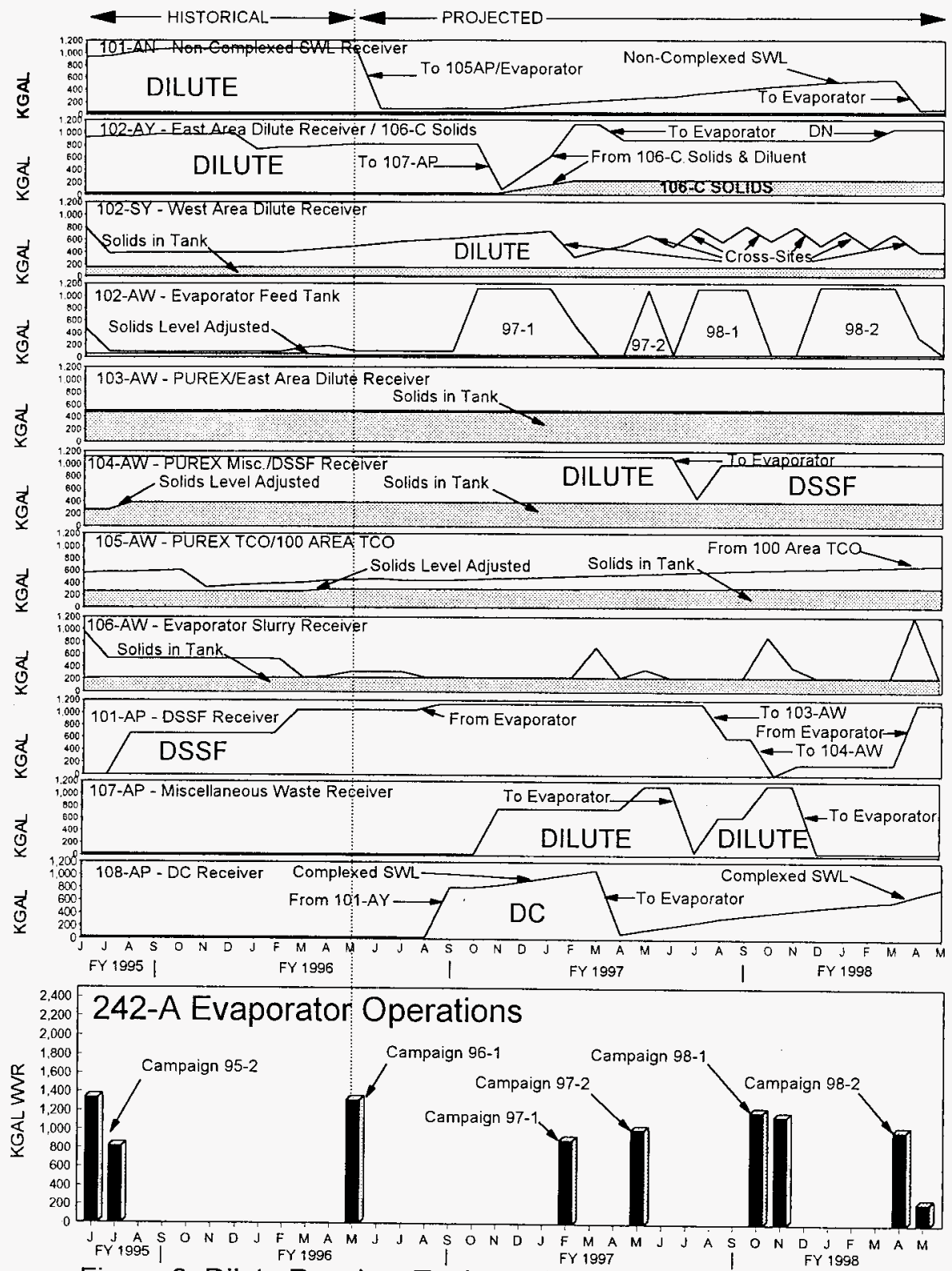

Figure 9. Dilute Receiver Tanks and 242-A Evaporator Operations 


\section{NON-AGING TANK SPACE}

In later parts of the projections when tank space becomes tight due to pretreatment needs and/or the amount of SST solids being retrieved, the evaporator is assumed to operate yearly to minimize waste storage needs and to decrease the volume of retrieved SST solids waste. Tank space pinches occurring between FY 2000 and FY 2015 (Figure 3) are caused by a combination of factors, including:

o SWL pumping (SST stabilization) volumes pumped by the end of FY 1999

o Four tanks are designated for staging wastes for Phase I pretreatment-two vendor tanks (Tanks 106-AP and 108-AP) and two intermediate staging tanks (Tanks 102-AP and 104-AP)

o The large volume of SST solids retrieved beginning in FY 2004

0 The decision not to operate the Grout. Facility has eliminated an early means of freeing up DST space

- The decision not to consolidate NCAW solids has increased the DST space needs from 2001 on

Figures 10 through 14 show the operation of most of the DST waste tanks for the Baseline Case projection. 
WHC-SD-WM-ER-029 Rev. 22
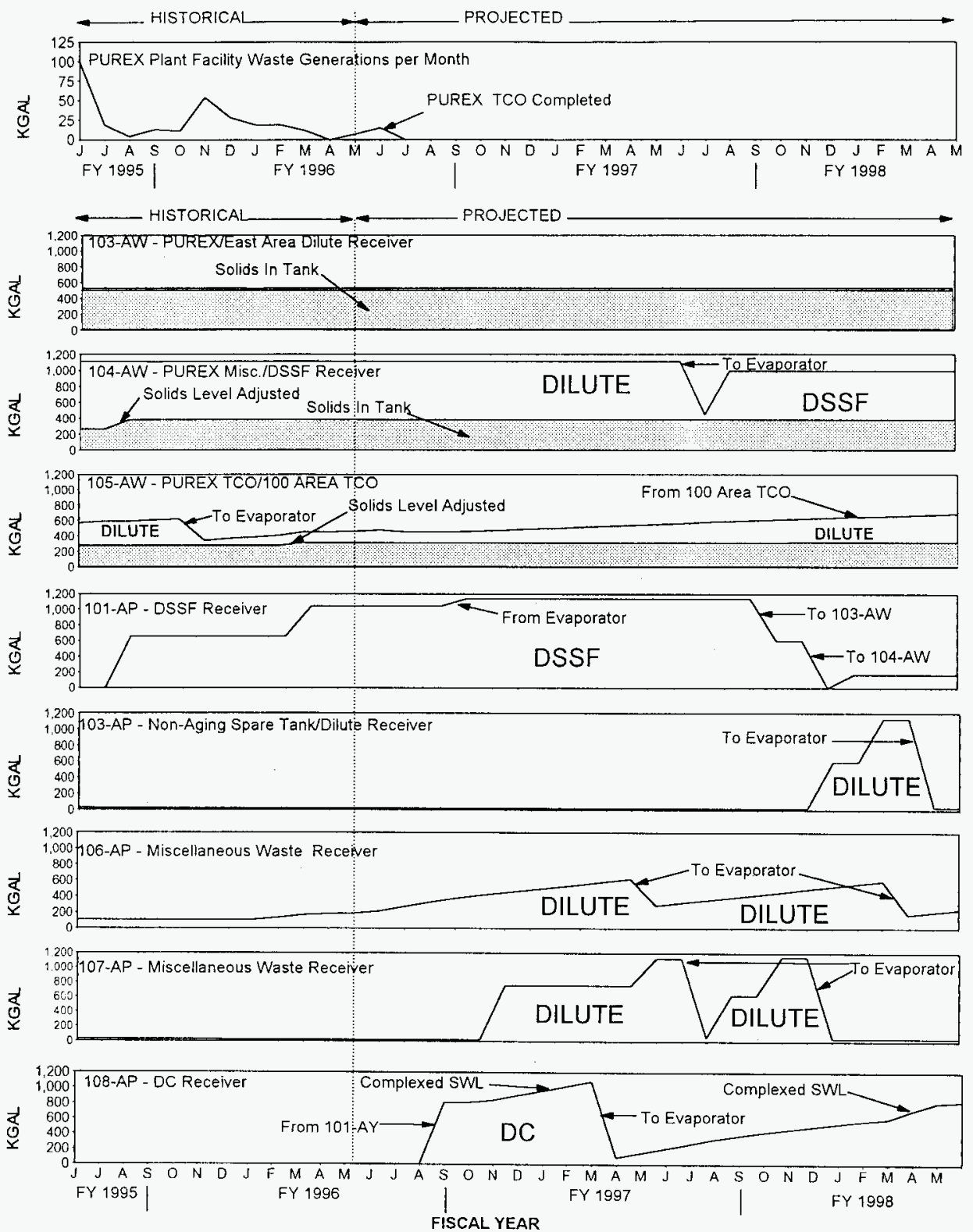

Figure 10. PUREX Facility Waste Generations and Tank Levels 
WHC-SD-WM-ER-029 ReV. 22
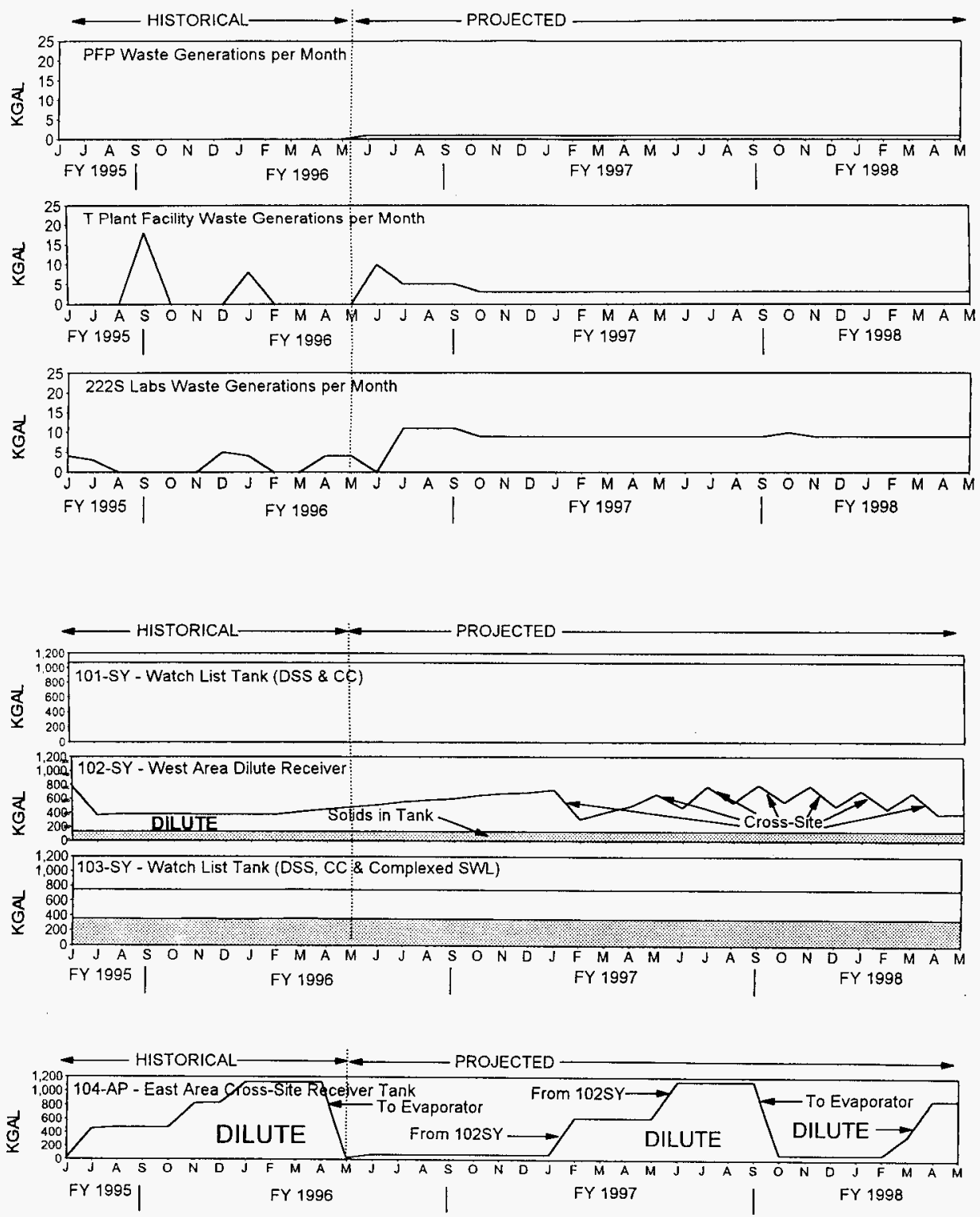

Figure 11. West Area Waste Generations and Tank Levels 

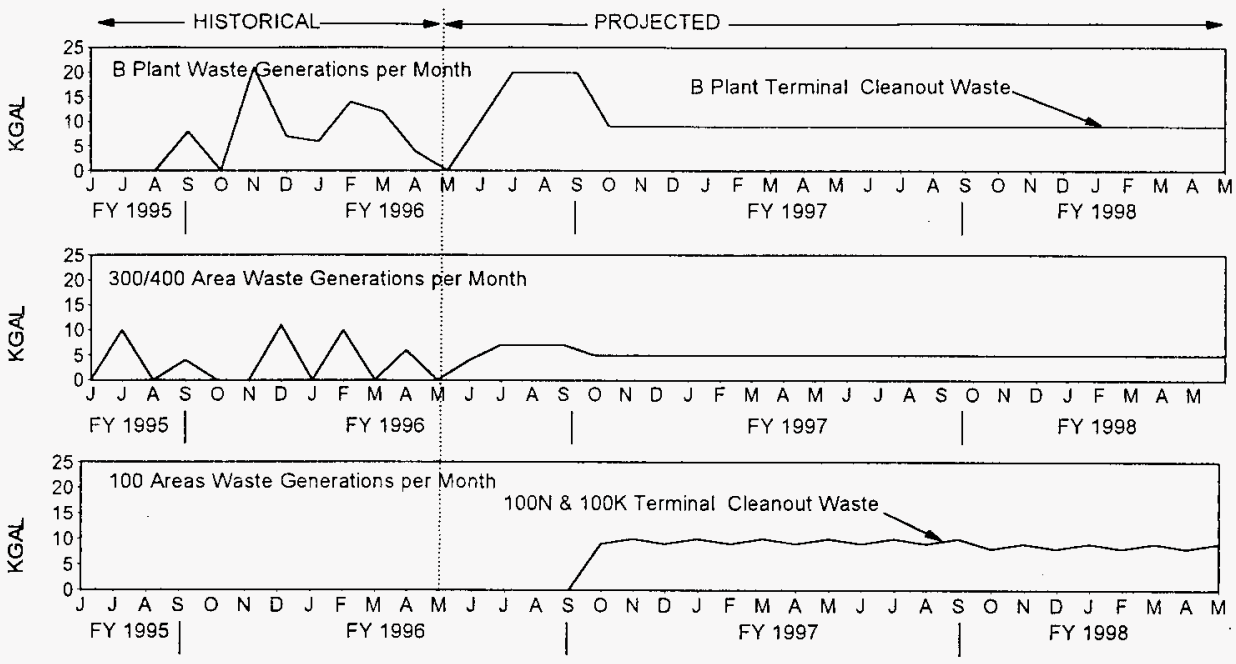

FISCAL YEAR
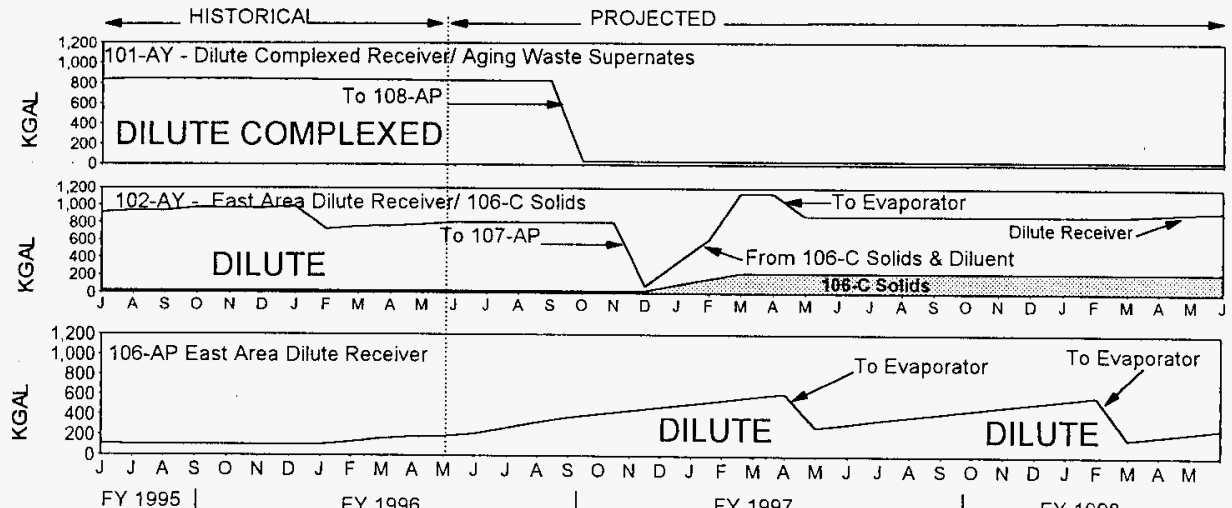
FY 1995 FY 1996

FISCAL YEAR 
WHC-SD-WM-ER-029 Rev. 22
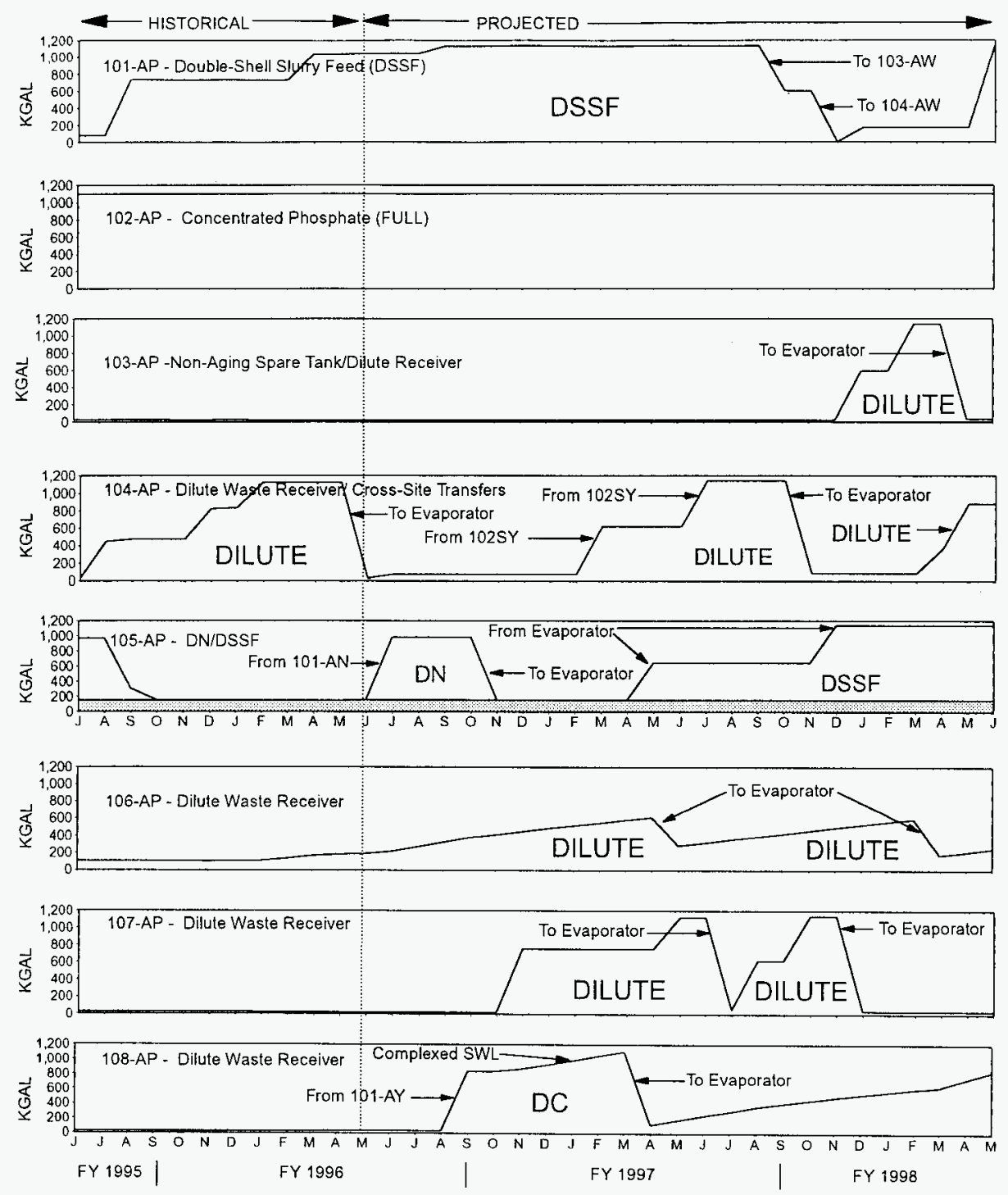

FISCAL YEAR

Figure 13. AP Tank Farm Levels 
WHC-SD-WM-ER-029 Rev. 22
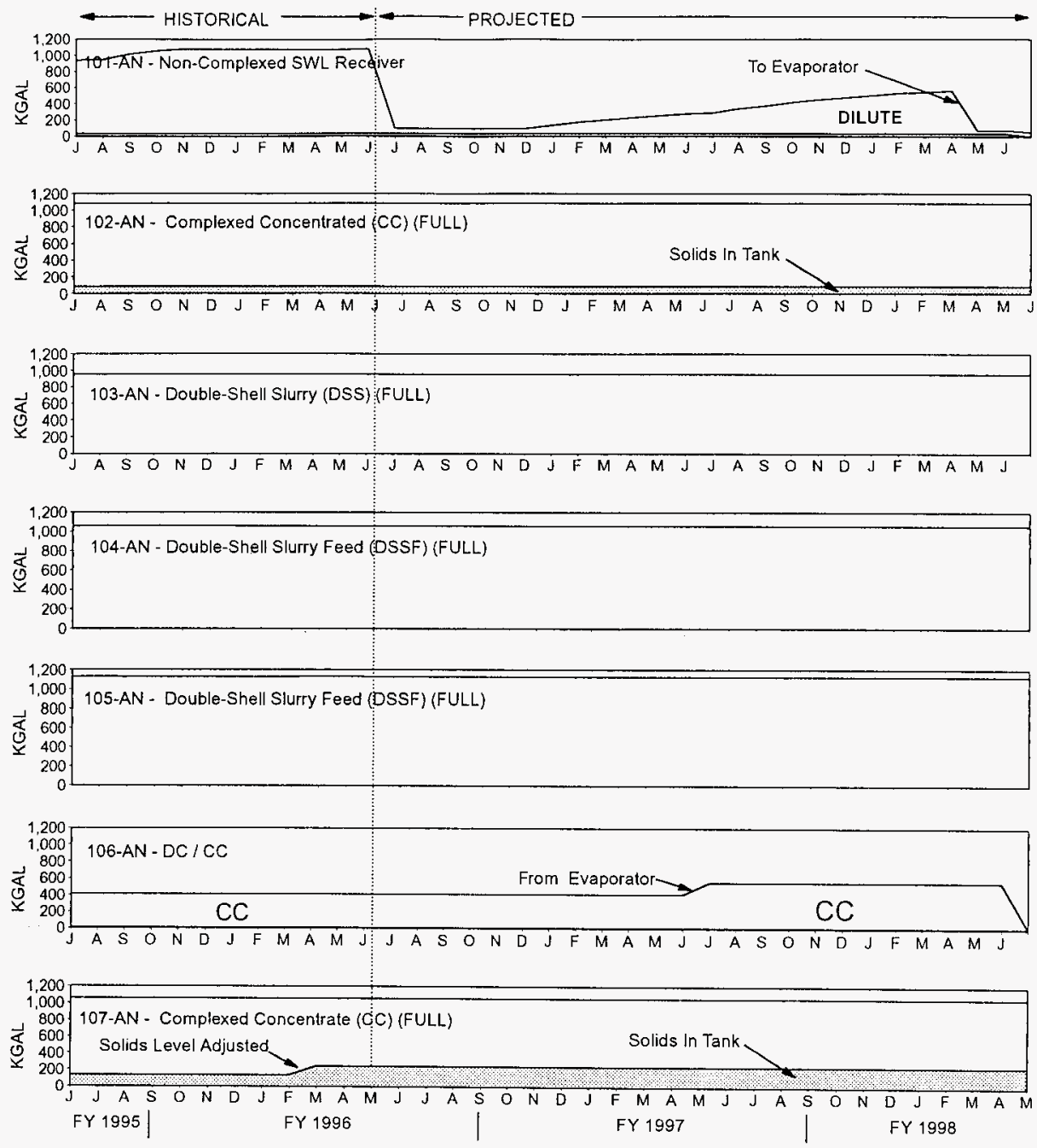

FISCAL YEAR

Figure 14. AN Tank Farm Levels 


\section{AGING WASTE TANK SPACE}

It is assumed that the PUREX facility will not restart. With PUREX not restarting only two aging waste tanks (Tanks $101-A Z$ and $102-A Z$ ) are required to store existing aging waste.

One additional aging waste tank will be required to retrieve and store the contents of Tank 106-C (a SST containing high heat waste). Waste from Tank 106-C is assumed to go to Tank 102-AY in FY 1997. This may cause a problem for final disposal of the contents of Tank 102-AY if the heel in Tank 102-AY is high in chlorides as indicated by initial characterization studies.

In Revision 21 of this document, it was assumed that all NCAW solids and the 106-C solids would be combined into one aging waste tank (Tank 102-AZ) and that all NCAW supernates would be concentrated into one aging waste tank (Tank 10l-AZ). Since that document was published, studies have been completed which looked at numerous sludge washing/combination options (Powe11, 1996a). The alternatives for consolidating high heat sludges have been reviewed by a decision board comprised of WHC management, a DOE/RL representative, and a WDOE representative. It was concluded that consolidating all the sludges into a single tank would require modifications to the tank farm safety basis. The preliminary decision reached was not to consolidate all the high heat sludges into a single tank. The selected alternative (Alternative 8 Modified) would wash the sludges in the tanks they reside in without additional consolidation of solids. The NCAW supernates could not be combined into a single aging tank (Tank 101-AY) due to the $5 \mathrm{M} \mathrm{Na}$ limit but would be concentrated and sent to Tank 101-AY and an additional non-aging tank (Powell, 1996b). This action has increased DST needs from FY 2001 as compared to Revision 21 DST space needs.

A graph of aging waste tank space requirements as a function of time is presented in Figure 15. The uses of each individual aging waste tank for the Baseline Case are shown in Figure 16.

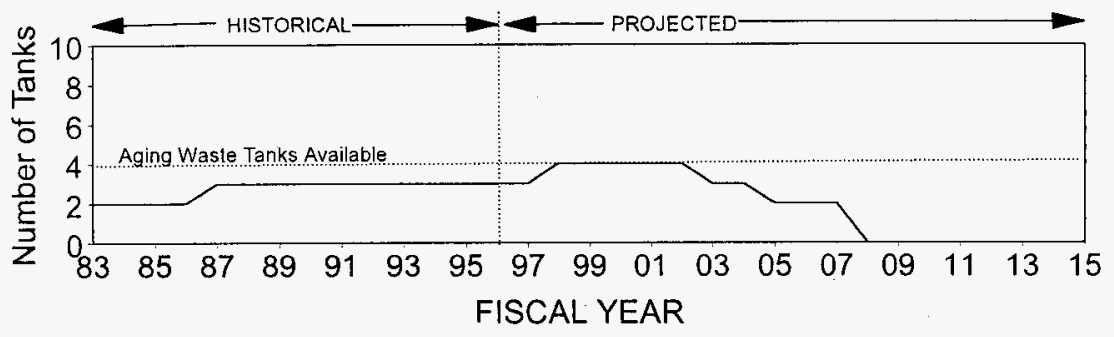

Figure 15. Aging Tank Requirements 


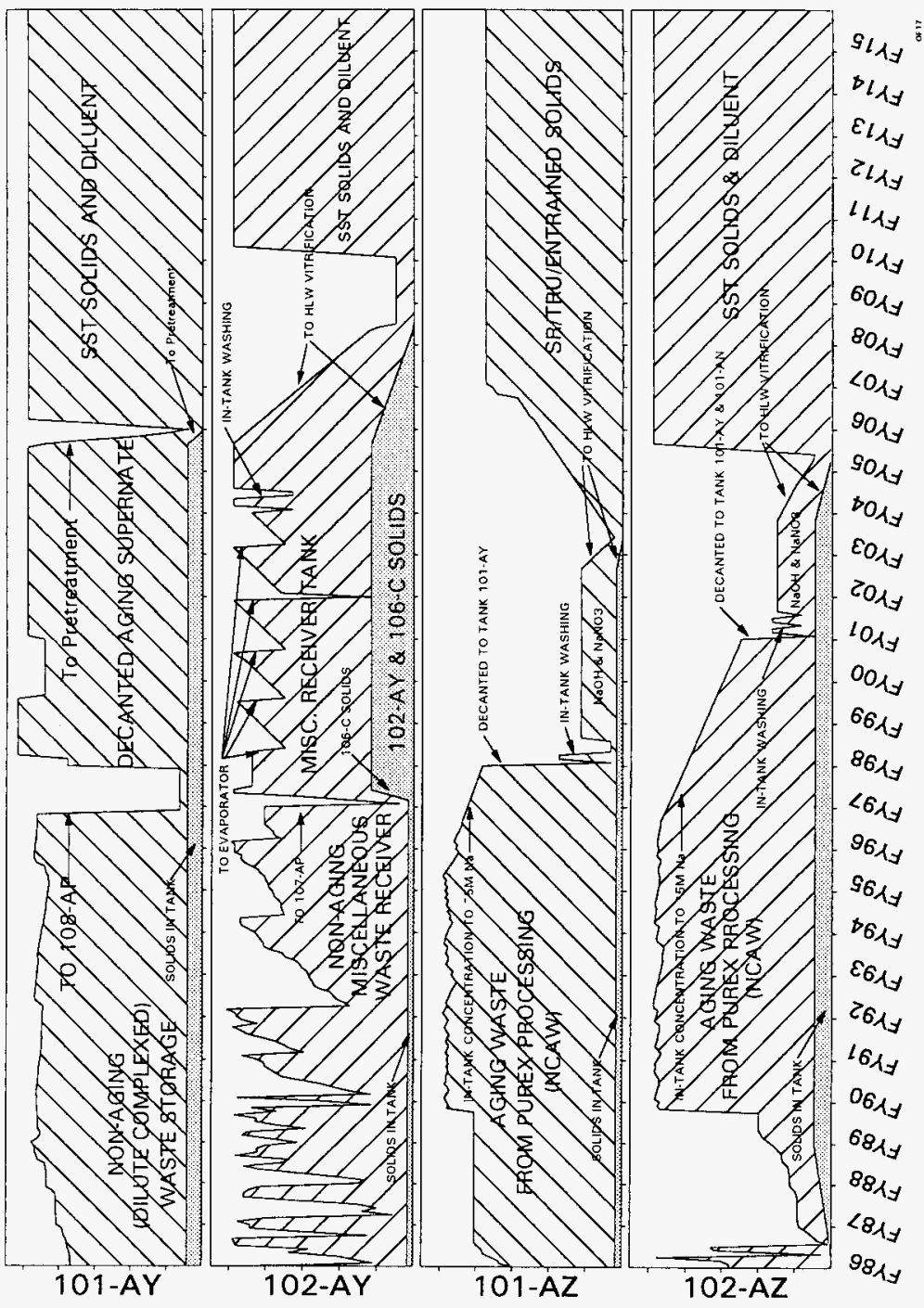

Figure 16. Aging Waste Tank Usage 


\subsection{Lower Planning Case Results and Conclusions}

Tank space needs for the Lower Planning Case are shown in Figure 17. Results from this projection indicate that decreasing the rate of SWL pumping during the period FY 1997-1998 would lower the DST space needs making reserve space available for other purposes. The SWL pumping volume for the Lower Planning Case was decreased by 2 million gallons during the period FY 1997-1998 but the reduction in tank count is only one tank. This anomaly is explained by the difference in actual stored volume for SWL. The waste volume reduction factor for non-complexed SWL is approximately 47 percent meaning that approximately 53 percent of the pumped volume difference would be translated into saved space or $1.06 \mathrm{Mgal}$ (one non-aging DST holds $1.14 \mathrm{Mgal}$ ).

The $2.4 \mathrm{Mgal}$ reduction in the SST solids retrieval volumes during the period FY 2006-2007 resulted in a two tank decrease in DST space needs until 2012. Reconcentration of the retrieved SST wastes was assumed to save approximately 25-30 percent of the retrieved volume resulting in approximately a two tank differential. Note that the magnitude of the volume saved by reconcentration of the retrieved SST solids waste will vary depending on what percent of the waste is dissolved saltcake and what portion is retrieval water added to retrieve SST solids. 


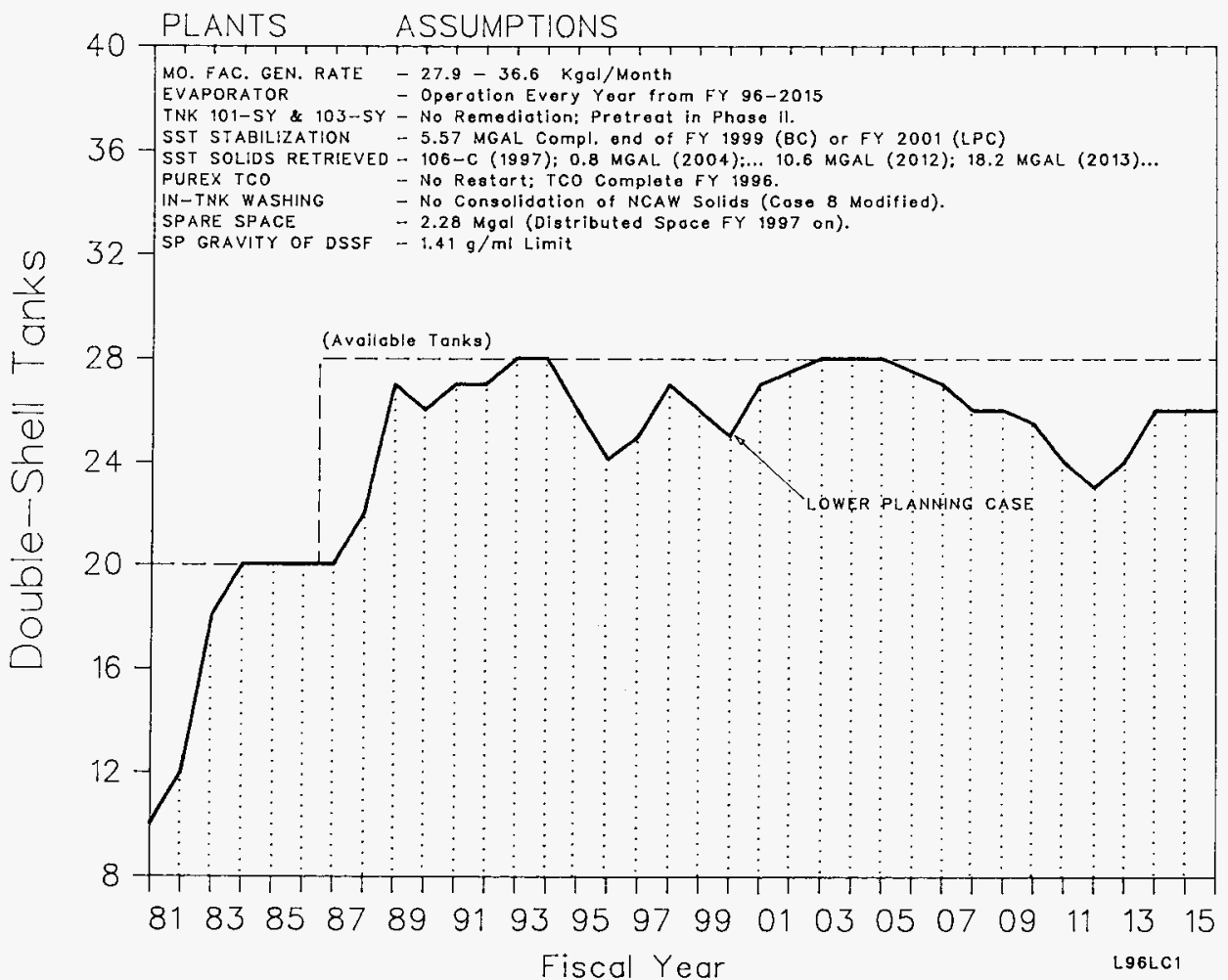

Figure 17. Double-Shell Tank Requirements for the Lower Planning Case 


\subsection{Upper Planning Case Results and Conclusions}

Tank space needs for the Upper Planning Case are shown in Figure 18 . The assumption changes and their impact are summarized below:

Loss of One Tank. The projected loss of tank space (tank 107-AN was taken out of service) in 1998 has increased tank space requirements by one tank and this in turn causes the projected tank space needs to exceed available space by the end of FY 2000 .

Evaporator Maintenance Outage. The evaporator maintenance outage in 2003 does not result in an increase in tank count because there is space available in Tank 102-AW and in the dilute receiver tanks to store the estimated $550 \mathrm{Kgal}$ of wastes to be evaporated in 2003. This result indicates that the evaporator maintenance outage could also be scheduled in other years when the projected WVR is low without impacting tank count.

Evaporator Shutdown. Knowing that the evaporator shutdown was going to occur in 2011, all dilute in the evaporator feed tank and dilute receiver tanks was evaporated off in 2010 to minimize impact of the shutdown. This resulted in some additional space to handle waste receipts in 2011-12 without impacting tank count. Note also that there were no SST solids retrieval volumes scheduled for 2011. By 2013 the available tank space has been grossly exceeded due to the large volume of SST solids waste retrieved in that year.

Assuming the evaporator shutdown was scheduled to occur, the only way to avoid exceeding the available space in 2013 is to decrease SST solids retrieval (TPA milestone), increase the pretreatment rate, or build additional tanks. By 2015, some of the SST retrieval cases (Washenfelder, 1996b) could result in retrieval of up to $34 \mathrm{Mgal}$ of waste per year. The maximum treatment rate of 22.1 Mgal/year (Washenfelder, 1996b) would not be able to handle the scheduled SST solid retrieval volumes. The results of the Upper Planning Case indicate that the evaporator capability needs to be maintained to avoid exceeding available tank space during SST solids retrieval. 


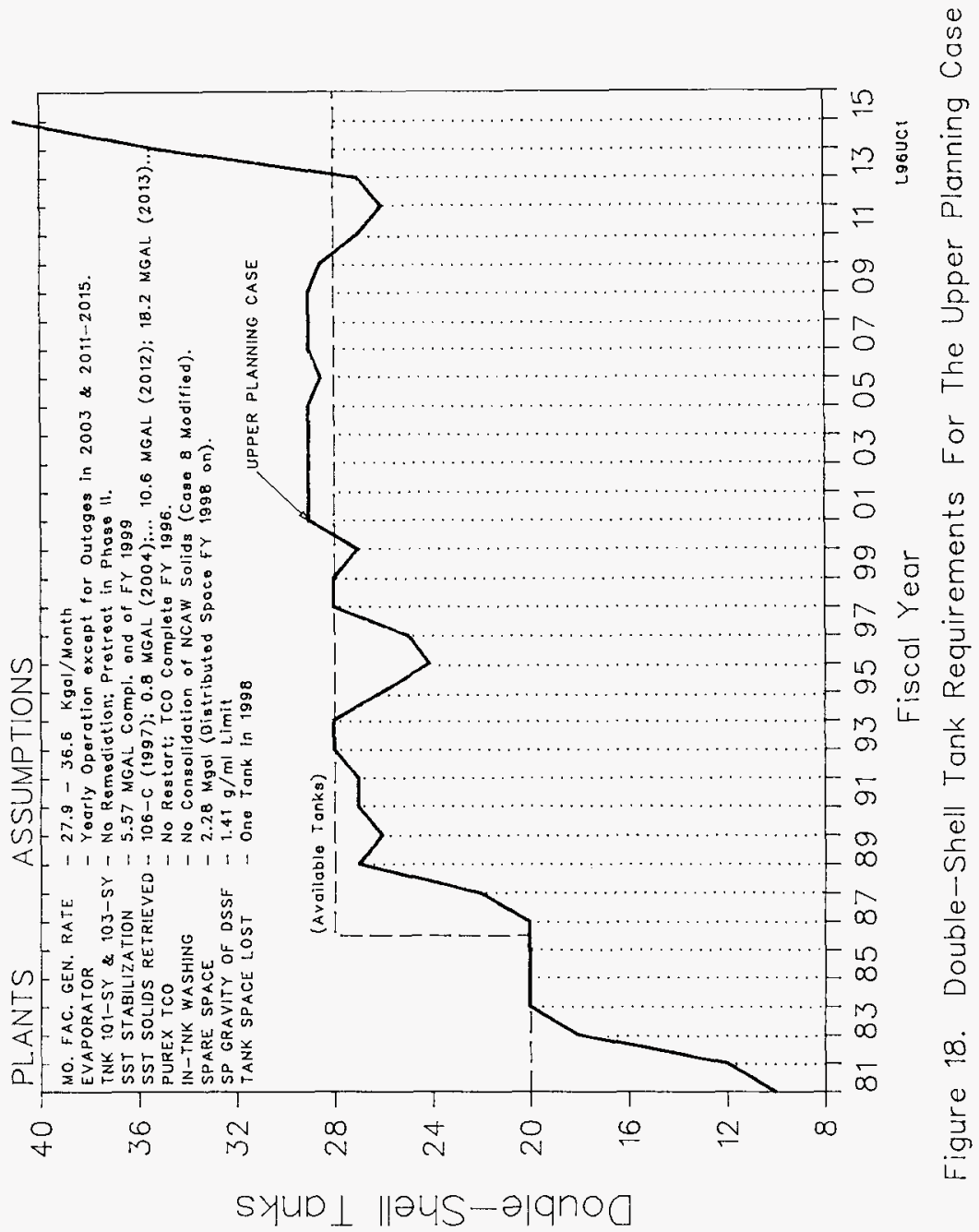




\subsection{Actual Waste Generation Compared to Management Limits}

During the Tank Space Management Board (TSMB) meeting on August 7, 1991, the need to establish new facility waste generation limits was discussed with the Hanford facility representatives based on additional delays in the 242-A Evaporator restart. A new total monthly waste generation rate of 64 $\mathrm{Kgal} /$ month was adopted based on: discussions with facility representatives, the average monthly waste generation rate for each facility during $F Y 1991$, and the need to provide contingency space for potential delays in the $242-A$ Evaporator restart.

Facility generation limits were not established for high priority waste generations, which were assigned to "Priority Space". These generations included the PFP stabilization campaign (safety), SWL pumping (TPA milestone), and the 242-A Evaporator (space necessary for the mini-run and restart).

New average monthly waste generation targets have been established for this projection with waste generations being reduced by the facilities (references and discussion in Section 3). Table 13 presents a comparison of the previous limits established for each facility, the newly established target rates for this projection, and the actual average monthly waste generation rate (Kgal/month) for the period October 1995 through June 30, 1996.

Table 13. Comparison of Average Monthly Waste Generation Rates (Kgal/month)

\begin{tabular}{|c|c|c|c|}
\hline FAC ILITY & $\begin{array}{l}64 \text { KGAL/MONTH } \\
\text { MANAGEMENT } \\
\text { LIMIT } \\
\text { FROM OWVP } \\
\text { REV. } 20\end{array}$ & $\begin{array}{l}\text { FACILITY } \\
\text { TARGET } \\
\text { FOR } \\
\text { REV. } 22\end{array}$ & $\begin{array}{c}\text { AVERAGE } \\
\text { MONTHLY FACILITY } \\
\text { GENERATIONS } \\
(10 / 95-6 / 96)\end{array}$ \\
\hline TANK FARMS & 10.0 & 10.0 & 7.3 \\
\hline B PLANT & 23.0 & 9.0 & 8.8 \\
\hline T PLANT & 6.0 & 3.6 & 2.7 \\
\hline S PLANT & 5.0 & 8.0 & 2.7 \\
\hline 300 AREA & 5.0 & 4.5 & 4.7 \\
\hline 400 AREA & 0.0 & 0.5 & 0.0 \\
\hline - & $64 \%$ & 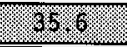 & $26 \%$ \\
\hline
\end{tabular}

\# Monthly Totals do not Include Terminal Clean-out Volumes or SWL Pumping

Due to the commendable efforts by the Hanford facilities, all waste generators are at or below their new waste generation target for the period 0ctober 1995 through June 30,1996 . A comparison of the volumes of waste entering the DST tank space for that time period is compared graphically to the various targets or projected generations in Figures 19-22. Estimated facility holdups or stored waste as of June 30,1996 are presented in Table 14. 


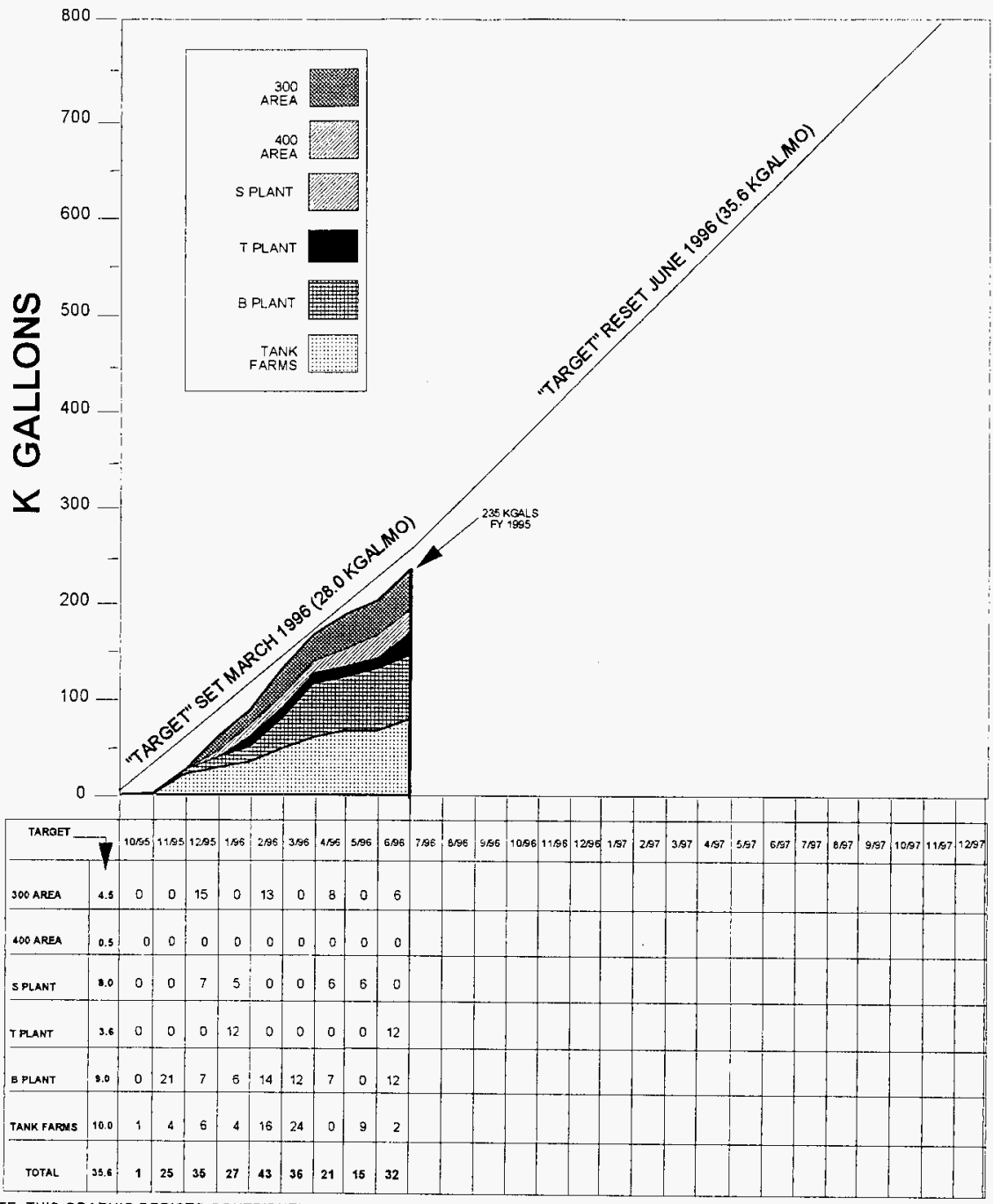

NOTE: THIS GRAPHIC DEPICTS CONTRIBUTIONS FROM FACILITY GENERATIONS; TERMINAL CLEAN-OUT AND SWL PUMPING IS NOT SHOWN

Figure 19. Comparison of Facility Generations to "TARGET" 
WHC-SD-WM-ER-029 Rev. 22

Comparison of the Average Monthly Waste Generation Rate (Kgal/month)

To their Respective Target Rate for the

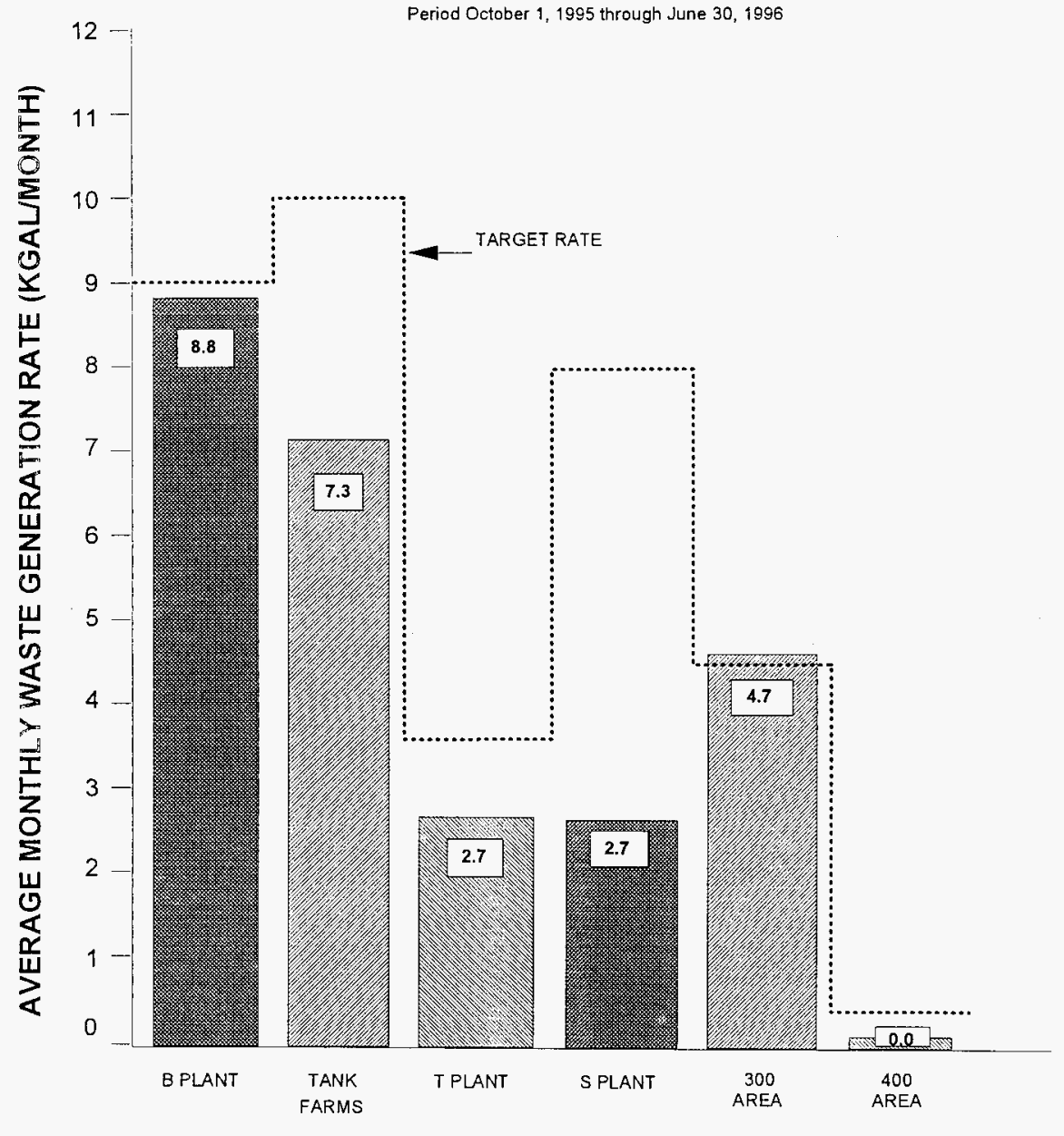

Figure 20. Comparison of Monthly Average Waste Generation To Target Rate 
WHC-SD-WM-ER-029 Rev. 22

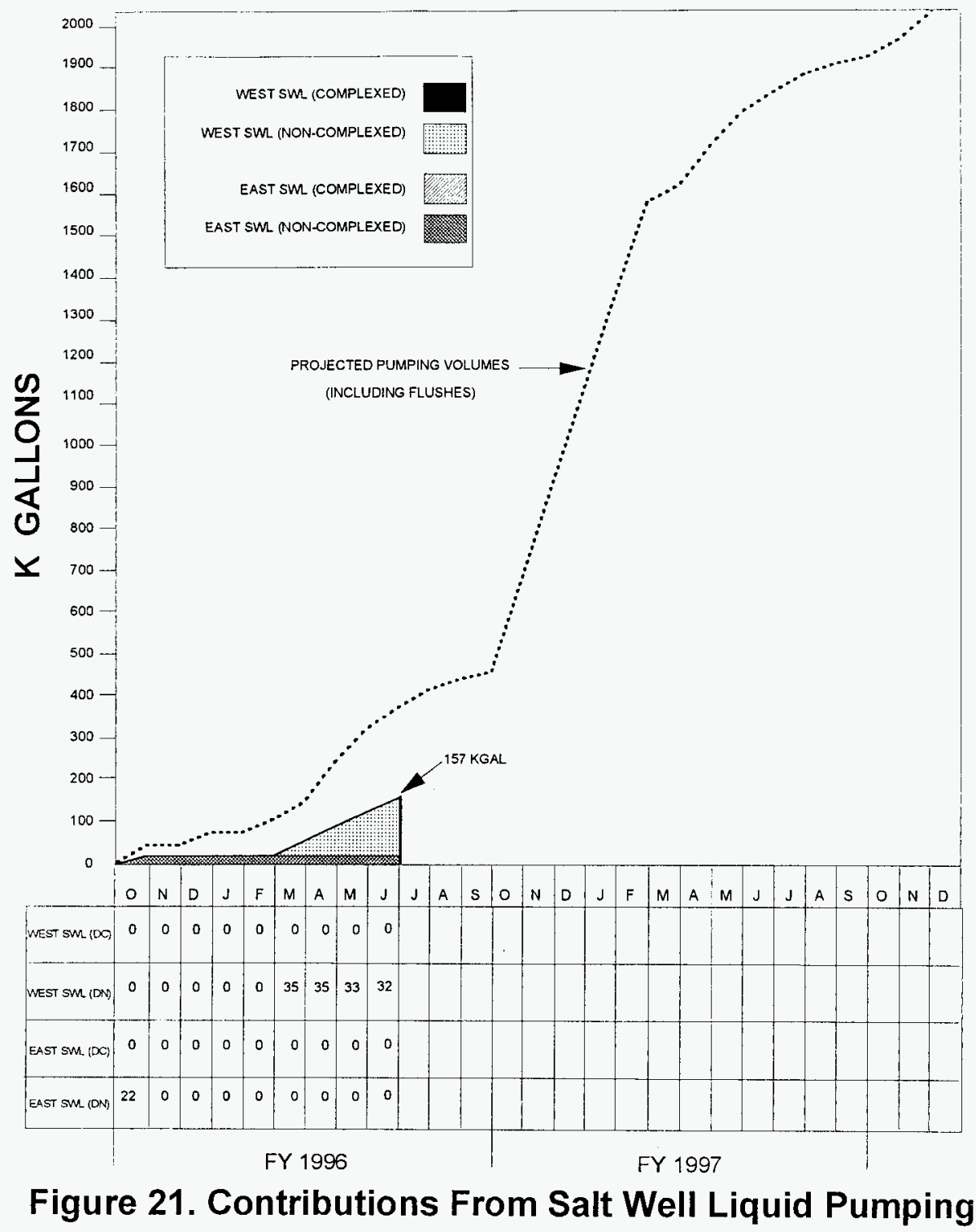


WHC-SD-WM-ER-029 Rev. 22

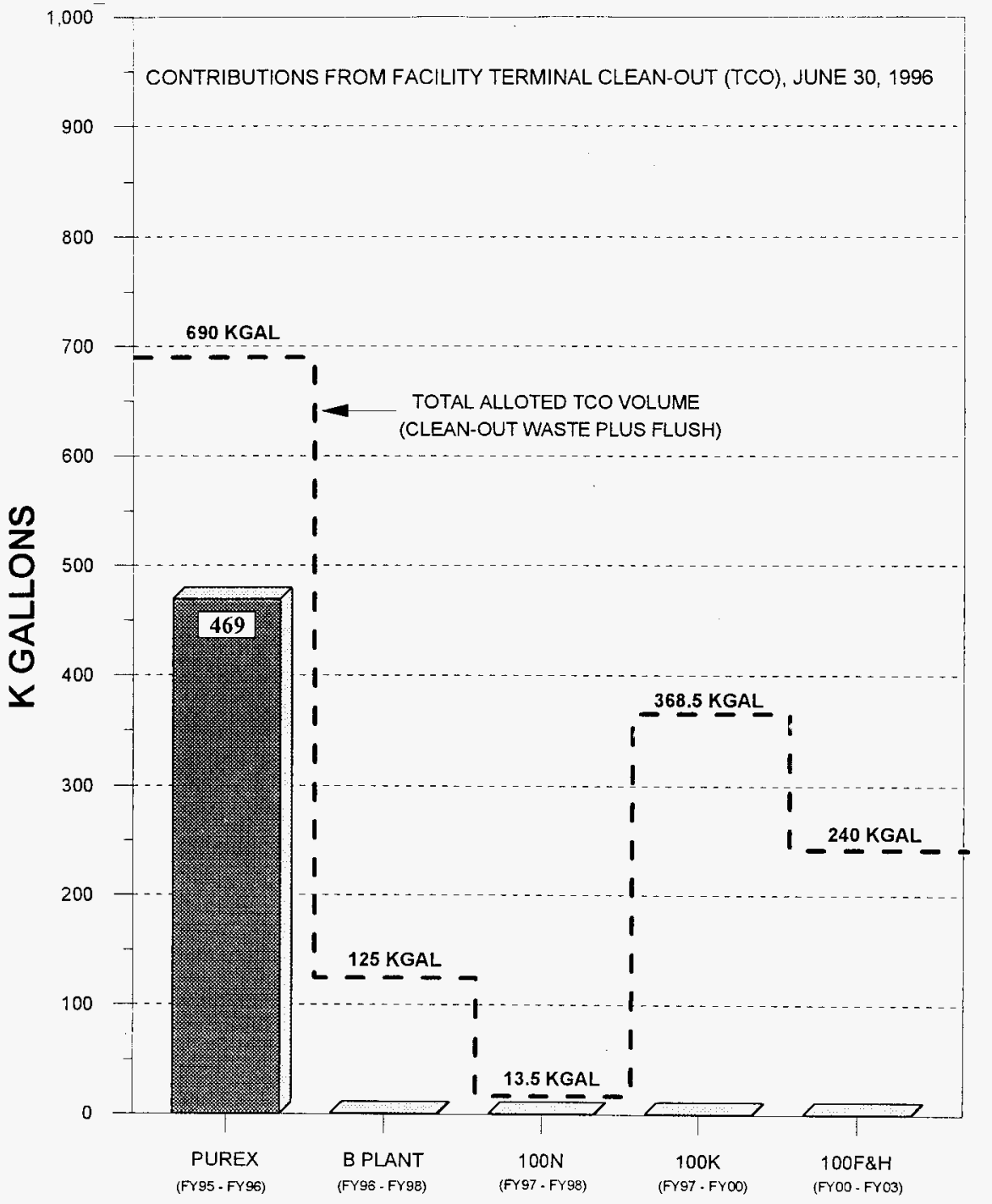

Figure 22. Contributions From TCO (June 30, 1996) 
WHC-SD-WM-ER-029 Rev. 22

Table 14. Facility Waste Storage and Capacity in Kgal as of June 1996

\begin{tabular}{|c|c|c|c|}
\hline FACILITY & ACTUAL HOLD-UP & $\begin{array}{c}\text { WASTE STORAGE } \\
\text { CAPACITY }\end{array}$ & $\begin{array}{c}\text { PROCESS VESSELS } \\
\text { CAPACITY }\end{array}$ \\
\hline PUREXX & & 100 & 215 \\
\hline B Plant & 10 & 0 & $\# 225$ \\
\hline S Plant & 2 & 9 & 0 \\
\hline T Plant & 17 & 50 & 0 \\
\hline 100 Area & 0 & 50 & 0 \\
\hline 300 Area & 7 & 60 & 0 \\
\hline 400 Area & 10 & 23 & 0 \\
\hline PFP & 2 & 16 & 0 \\
\hline TOTAL $=$ & 48 & 308 & 440 \\
\hline
\end{tabular}

\# $25 \mathrm{Kgal}$ capacity for storage of waste, the remaining space is not routed for storage (Killoy, 1992). 


\subsection{SPACE SAVING ALTERNATIVES}

In the near term, space saving alternatives include waste minimization, continued availability of the 242-A Evaporator, LERF availability, and the operation of the ETF. These alternatives must be considered because new inputs to the system may develop (e.g., unexpected new waste streams or a leaking SST or DST).

Should a tank space shortage develop in the period 1998 through 2015, response to the shortage for the Baseline Case must be in one of three areas. The inflows to the system must be reduced, the outflows to the system must be increased (or started earlier), or the available tank space increased.

Inflows to the system include miscellaneous facility waste generations, TCO wastes, in-tank washing, dilution of Tanks 101 and 103-SY (for pretreatment), pretreatment, SWL pumping, and SST solids retrieval. Outflows include the 242-A Evaporator and waste disposal (pretreatment and vitrification). Increasing the tank space available could be done by building more tanks (a six to eight year task), mixing segregated waste types (which would gain about half a million gallons of space but increase interim storage and final disposal costs), or operating without reserved spare tank space. A cost/benefit analysis needs to be completed to determine the best alternative.

In addition to minimizing waste generations, other actions could be pursued. The list below includes many actions which can result in tank space savings or economization, and can serve as a starting point in a tank space optimization program.

\section{PUREX Facility}

- $\quad$ TCO of PUREX will be completed by FY 1997. Most of the volume to be transferred from the PUREX facility to DSTs has already been received. Therefore, waste reductions for PUREX

B Plant will not be a viable option.

- $\quad$ Continue to reduce waste being generated at $B$ Plant

- Route BCP waste to cribs

- Evaporate dilute waste, from B Plant and other facilities, in B Plant concentrators

- Replace steam heaters with electric heaters

- Make TCO at B Plant dependent on tank space availabiTity

\section{Plutonium Finishing $\mathrm{Plant}$}

Continue to reduce waste being generated at PFP (only $30 \mathrm{Kgal}$ of total waste are scheduled to be generated from FY 19962006 


\subsection{SPACE SAVING ALTERNATIVES (CONTINUED)}

\section{Tank Farms}

\begin{tabular}{|c|c|}
\hline & Continue to reduce waste being added to DSTs \\
\hline- & Continue waste accountability and minimization controls \\
\hline- & Develop a total waste cutoff plan \\
\hline - & Increase the $5 \mathrm{M} \mathrm{Na}$ limitation on aging waste tanks \\
\hline- & $\begin{array}{l}\text { Use dilute waste for retrieval, air lift circulator flushes, } \\
\text { line flushes, etc. }\end{array}$ \\
\hline- & Increase the WVR of the 242-A Evaporator \\
\hline- & $\begin{array}{l}\text { Accelerate plans to consolidate solids from Tanks 102-SY into } \\
\text { Tank 105-AW }\end{array}$ \\
\hline - & Delay SWL pumping \\
\hline - & Build new tanks \\
\hline - & $\begin{array}{l}\text { Accept loss of waste segregation (used in an extreme } \\
\text { emergency) }\end{array}$ \\
\hline - & $\begin{array}{l}\text { Store facility generated waste in designated "spare tank } \\
\text { space" (used in an extreme emergency) }\end{array}$ \\
\hline - & Improve efficiency of the 242-A Evaporator \\
\hline - & $\begin{array}{l}\text { Solidify treated waste and dispose of as low level waste in } \\
\text { burial grounds }\end{array}$ \\
\hline - & $\begin{array}{l}\text { Consolidate NCAW and Tank 106-C solids in one aging tank with } \\
\text { one additional aging tank being used to combine NCAW } \\
\text { supernates (requires modification of safety basis). }\end{array}$ \\
\hline - & $\begin{array}{l}\text { Increase the heat } 1 \text { imit on non-aging DSTs to allow either the } \\
\text { Tank 106-C wastes or the supernate from Tank } 101-A Z \text { to be } \\
\text { stored in a non-aging DSTs if the in-tank washing } \\
\text { consolidations are not allowed }\end{array}$ \\
\hline- & $\begin{array}{l}\text { Concentrate DSSF to Double-Shell Slurry (DSS). Experience } \\
\text { with Tank 101-SY makes this alternative highly untikely. }\end{array}$ \\
\hline- & $\begin{array}{l}\text { Store waste in single-shell tanks (used in an extreme } \\
\text { emergency; would require approval by DOE, EPA, and Ecology) }\end{array}$ \\
\hline - & $\begin{array}{l}\text { Store waste in facility storage tanks or portable tanks such } \\
\text { as railcars (used in an extreme emergency; total space } \\
\text { available is small compared to the contents of a DST) }\end{array}$ \\
\hline
\end{tabular}

Grout

- Reinstate the Grout Disposal Program

- Grout the existing waste in Tanks 102-AP and 101-AW 


\subsection{BIBLIOGRAPHY}

Alderman, C. J., January 29, 1996, Internal Memo (CJA-96-002) to J. N. Strode, "Waste Volume Projection Assumptions for K Basins Sludge."

Anantatmula, R. P. and Oh1, P. C., June 28, 1996, WHC-SD-WM-ER-0585, Rev. 0, "DST Remaining Useful Life Estimates."

Awadalla, N. G., April 19, 1995, WHC-SD-W236A-ER-021, Rev. 1, "Multi-Function Waste Tank Facility, Phase Out Basis."

Barrington, C. A., May 7, 1991, Letter to J. G. Propson, "Plutonium Finishing Plant Waste Volume Projection for Fiscal Years 1991 - 2015."

Barton, W. B., May 16, 1996, Internal Memo (74A10-96-066) to Distribution, "Operational Waste Volume Projection Assumptions for 1996."

Bergquist, G. G., January 1, 1996, Internal Memo (15530-96-GGB-010) to J. N. Strode, "Plutonium Finishing Plant Waste Volume Projection for the Period Fiscal Year 1996-2028."

Brown, R. G., May 1996, WHC-SD-W236A-ES-012, Rev. 1, "Multi-Function Waste Tank Facility Path Forward Engineering Analysis Technical Task 3.3, SingleShe11 Tank Contents."

Carothers, K. G., January 30, 1996a, Personal Communication with J. N. Strode, Caustic Addition to Tank 107-AN--Revised Schedule.

Carothers, K. G., March 19, 1996b, Personal Communication with J. N. Strode, Caustic Addition to Tank 107-AN--Revised Schedule.

Certa, P. J. and D. L. Penwe11, Received JuTy 13, 1995, Personal Communication--Hardcopy of Retrieval Sequence RE087SST.TXT for "2C3-087"-Ramped Pretreatment.

Certa, P. J., et. al., August 1996, WHC-SD-WM-RPT-224, Rev. 0, "Low-Leve? Waste Feed Staging Plan."

Collins, G. T., January 31, 1996, Internal Memo (75755-96-006) to J. N. Strode, "Waste Volume Projection Assumptions for 222-S Laboratory and the Waste Sampiing and Characterization Facility (WSCF) for the Period FY 19962028."

DOE Order RL 5820.2A, August 1990, Radioactive Waste Management, Waste Management Div., U.S. Department of Energy, Richland, Washington.

DOE 1995, January 24, 1995, memorandum from T. P. Grumbly, Assistant Secretary for Environmental Management to the Department of Energy Secretary, U. S. Department of Energy, Washington, D. C., "Proceed with privatization of Hanford tank waste treatment by consulting with regulators, the Hanford Advisory Board, and other stakeholders, and to establish a full-time DOE task force to carry out the necessary procurement steps to implement privatization." 


\subsection{BIBLIOGRAPHY (CONT INUED)}

Estey, S. D., May 31, 1994, WHC-SD-W320-TI-002, Rev. OA, "Project W-320 Tank 241-C-106 Sluicing Process Flowsheet."

Estey, S. D. and Guthrie, M. D., March 29, 1996, Internal Memo (74A10-96-029) to N. G. Awadalla, "Data Analys is and Criteria Development to Prevent Accumulation of DST Waste With Unacceptable Gas Retention Behavior."

Estey, S. D., April 1996, WHC-SD-WM-TI-747, Rev. 0, "TRU Activity and Complexed Waste Considerations for 200 West Area SST Interim Stabilization Planning."

Ethington, P. R., February 5, 1996, Interna7 Memo (17330-96-009) to N. W. Kirch, "Forecasted PUREX Plant Liquid Waste."

Fowler, K. D., April 1995a, WHC-SD-WM-OCD-015, Rev. 1, "Data Quality Objectives for Tank Farms Waste Compatibility."

Fowler, K. D., April 1995b, WHC-SD-WM-DQ0-001, Rev. 1, "Data Quality Objectives for Tank Farms Waste Compatibility Program."

Greenidge, M. E., February 29, 1996, Letter (027213) to W. B. Barton, "Waste Volume Projection Assumptions for 100-N Area Facilities for the Period FY 1996-2028."

Griffin, P. W., February 14, 1996, cc: Mail Message to J. N. Strode, "Waste Volume Projection Assumption for 105-F and 105-H Basins."

Grumbly, T. P., August 1993, "Safety Initiatives."

Guthrie, M. D., August 18, 1993, Letter to G. M. Koreski and J. N. Strode, "Assumptions for the Operational Waste Volume Projection (for the 242-A Evaporator)."

Guthrie, M. D., January 26, 1996, Internal Memo (77310-96-005) to J.N. Strode, "1996 242-A Evaporator Waste Projection Assumptions."

Guthrie, M. D., August 1996b, WHC-SD-WM-PE-056 Rev. 0 Draft, "Campaign 96-1 Post Run Document."

Haigh, P. G., January 21, 1992, Personal Communication.

Halgren, D. L., February 3, 1995, Internal Memo (86730-95-005) to J. N. Strode, "Waste Volume Projection Assumptions for the 300 Area for the Period of Fiscal years 1995-2028."

Halgren, D. L., June 21, 1995, CC: Mail Message to J. N. Strode, "340 Waste volume."

Han7on, B. M., March 1996, WHC-EP-0182-96, "Waste Tank Summary Report for Month Ending March 31, 1995." 


\subsection{BIBLIOGRAPHY (CONTINUED)}

Hanson, G. N., September 9, 1996, cc: Mail Message to W. B. Barton, "Comments WHC-SD-WM-ER-029 Rev 22."

Hepner, N. T., cc: Mail Message to consider one tank loss.

Koreski, G. M., August 30, 1995, DSI to Jim Strode, "Comments on Solids Levels in Table 7 (6/95 OWVP)."

Kutsch, D. B., January 10, 1996a, Internal Memo (16D20-96-0BK-011) to J. N. Strode, "B Plant Assumption for Waste Volume Projections for 1996 Through 2028."

Kutsch, D. B., March 26, 1995b, cc: Mail Message to J. N. Strode, "B P1ant Waste Volume Projection (corrected)."

McKenney, D. E., May 13, 1994, DSI to Nick Kirch, "Leachate Composition from Mixed Waste Landfill."

Miller, P. C., January 16, 1996, Internal Memo (RC-96-001) to J. N. Strode, "Waste Volume Projection Assumptions for 400 Area for the Period FY 19962028."

Orme, R. M., March 1995a, WHC-SD-WM-TI-693 Rev. 0, "Preliminary Time-Phased TWRS Process Model Results."

Orme, R. M., August 1995b, WHC-SD-WM-TI-613 Rev. 1, "TWRS Process Flowsheet."

Powe11, W. J., January 22, 1996, WHC-SD-WM-ER-532, Rev.0, "Neutra1 ized Current Acid Waste Consolidation Management Plan."

Powe11, W. J., February 23, 1996, cc: Mail Message to W. B. Barton, "Modified NCAW Alternative 8."

Reynolds, D. A., March 8, 1994, Presentation at the Meeting- Assumption Changes for the Operational Waste Volume Projection.

Reynolds, D. A., May 3, 1995, WHC-SD-W236A-ES-015, Rev. 0, "Waste Segregation Analysis for Salt Well Pumping the the 200 West Area - Task 3.4."

Riley, D. C. et a1, March 1988, SD-WM-TI-309, Rev. 1, "Waste Generation and Processing Rates with Volume Reduction Factors - 1988."

Saueressig, D. L., Information Received at a Meeting held March 13, 1996, March 5, 1996 Draft of Interim Stabilization Tri-Party Agreement M-41-00 Recovery Plan."

Sederburg, J. P., April 1995, WHC-SD-WM-TI-690, Rev. 0, "Waste Volume Reduction Factors for Potential 242-A Evaporator Feed." 


\subsection{BIBLIOGRAPHY (CONTINUED)}

Shelton, L. W. Jr., July 28, 1995, cc: Mail Message to J. N. Strode, "Tank Inventories."

Smith, D. K., February 25, 1994, Internal Memo (16500-94-DKS-023) to G. M. Koreski/J. N. Strode, "B Plant Comments on the Assumptions for the Operational Waste Volume Projection."

Triner, G. C., January 10, 1996, Internal Memo (87470-96-GCT-002) to J. N. Strode, "Waste Volume Projection Assumptions for T Plant for the Period FY 1996-2028."

Von Bargen, B. H., April 25, 1995, WHC-SD-WM-DQ0-014, Rev. 1, "242A Evaporator/Lerf Data Quality Objective."

Wacek, H. J., June 28, 1996, cc: Mai1 Message, "Operational Waste Volume Projection Assumptions for 1996."

Wagner, R. N., January 29, 1996, cc: Mail Message to J. N. Strode, "(ETF) WVP As sumptions."

Wang, 0. S., March 1, 1994, cc: Mail Message to G. M. Koreski and J. N. Strode, "Assumptions for the Operational Waste Volume Projection."

Washenfelder, D. J., June 26, 1996a, DSI to W. B. Barton, "Revised Attachment 1 to Internal Memo Titled "Revised TWRS Disposal Program Assumptions for Operational Waste Volume Projection-73410-96-013"."

Washenfelder, D. J., July 29, 1996b, DSI to W. B. Barton, "Revised Attachment 1 and 2 to Internal Memo Titled "Revised TWRS Disposal Program Assumptions for Operational Waste Volume Projection-73410-96-013"."

Washington State Department of Ecology (WDOE), U.S. Environmental Protection Agency, and U. S. Department of Energy, Fourth Amendment, January 1994, "Hanford Federal Facility Agreement and Consent Order" (Tri-Party Agreement).

WHC 1996a, July 3, 1996, "Federal Facility Agreement and Consent Order Change Control Form," Change Number M-60-95-03.

WHC 1996b, July 3, 1996, "Federal Facility Agreement and Consent Order Change Control Form," Change Number M-50-95-01. 
WHC-SD-WM-ER-029 Rev. 22

APPENDIX

A-1 


\section{APPENDIX. Acronyms}

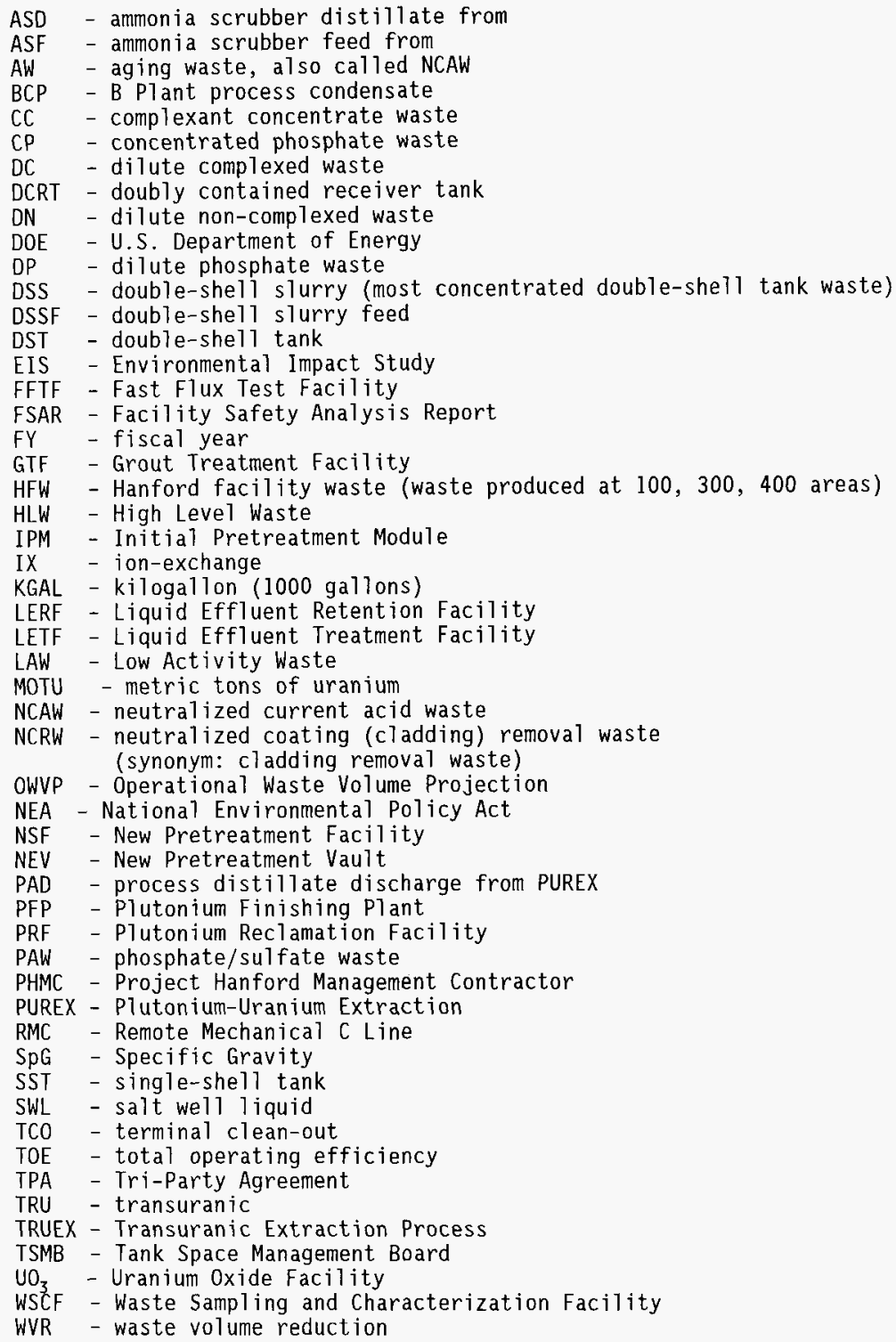




\section{INTERNAL DISTRIBUTION}

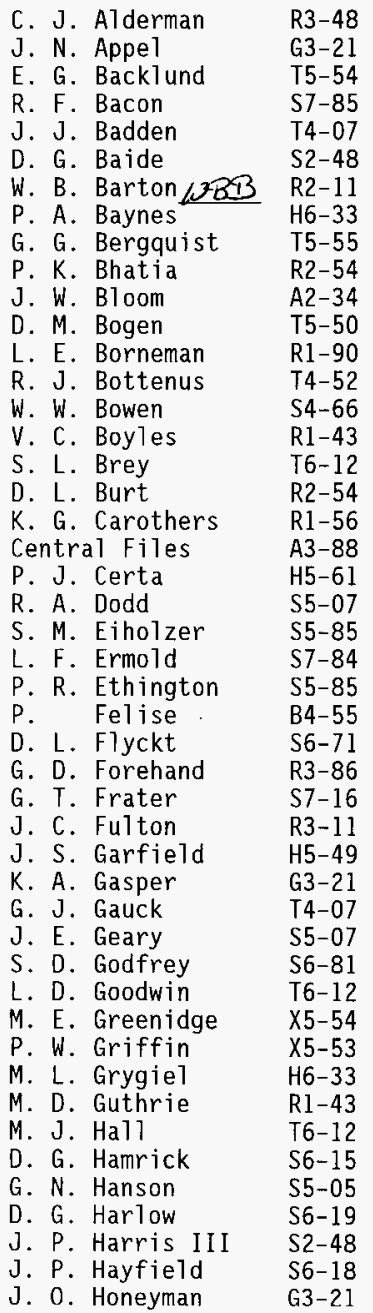


WHC-SD-WM-ER-029 2 of 3

INTERNAL DISTRIBUTION (CONTINUED)

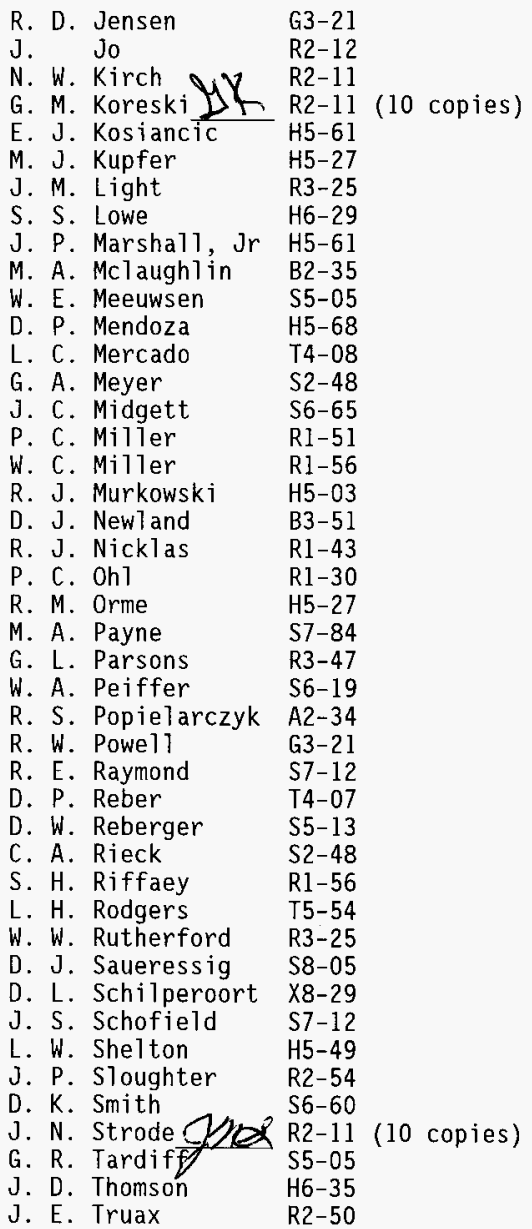


INTERNAL DISTRIBUTION (CONTINUED)
A. M. Umek
57-81
J. E. Van Beek
S2-48
E. C. Vogt
T5-50
B. H. Von Bargen
R1-43
J. A Voogd
H5- 03
B. L. Wallace
S6-60
G. L. Walley
T6-20
D. J. Washenfelder
R. A. Watrous
H5-27
D. J. Watson
H5-27
J. H. Wicks, Jr.
$\times 3-79$
K. D. Wiemers
R2-50
J. 0. Williams
$\mathrm{K} 6-51$
G. F. Williamson
H6-30
C. M. Winkler
$\mathrm{H} 5-03$
R. D. Wojtasek
S5-14
C. D. Wollam
$57-84$
R. B. Wurz
$56-22$
S6-71

\section{DEPARTMENT OF ENERGY (DOE RL)}
M. L. Ramsay
S7-54
A. B. Sidpara
$57-54$
H. J. Wacek
$57-54$
D. D. Wodrich
$\$ 7-50$

\section{WASHINGTON STATE DEPARTMENT OF ECOLOGY}

Nuclear \& Mixed Waste Management Program P.0. Box 47600

Olympia, WA 98504-7600

N. T. Hepner 